GABRIEL BASSETTI MARTINHO

MELHORIA DE PROCESSOS EM EMPRESAS DO SETOR DE VAREJO NO BRASIL: ESTUDO DE CASOS 
GABRIEL BASSETTI MARTINHO

MELHORIA DE PROCESSOS EM EMPRESAS DO SETOR DE VAREJO NO BRASIL: ESTUDO DE CASOS

Dissertação apresentada à Escola Politécnica da Universidade de São Paulo para a obtenção do título de Mestre em Engenharia 
Gabriel Bassetti Martinho

\section{MELHORIA DE PROCESSOS EM EMPRESAS DO SETOR DE VAREJO NO BRASIL: ESTUDO DE CASOS}

Dissertação apresentada à Escola Politécnica da Universidade de São Paulo para a obtenção do título de Mestre em Engenharia

Área de Concentração:

Engenharia da Produção

Aprovado Em:

\section{Banca Examinadora}

Prof. Dr.:

Instituição: Assinatura:

Prof. Dr.:

Instituição: Assinatura:

Prof. Dr.: Instituição: Assinatura: 

VAREJO NO BRASIL: ESTUDO DE CASOS

Dissertação apresentada à Escola Politécnica da Universidade de São Paulo para a obtenção do título de Mestre em Engenharia

Área de Concentração:

Engenharia da Produção

Orientador:

Prof. Dr. Roberto Gilioli Rotondaro 
FICHA CATALOGRÁFICA

Martinho, Gabriel Bassetti

Melhoria de processos em empresas do setor de varejo no

Brasil: estudo de casos / G.B. Martinho. -- São Paulo, 2011. $131 \mathrm{p}$.

Dissertação (Mestrado) - Escola Politécnica da Universidade de São Paulo. Departamento de Engenharia de Produção. 
Dedico este trabalho a todos que me apoiaram durante esse período 


\section{AGRADECIMENTOS}

Ao meu orientador professor Roberto Gilioli Rotondaro pela disponibilidade e conselhos empenhados durante o processo de elaboração deste trabalho.

Aos professores Marly Monteiro de Carvalho e Marilson Alves Gonçalves pela colaboração e apoio durante o desenvolvimento deste trabalho.

À Escola Politécnica e a todos os professores e funcionários do Departamento de Engenharia de Produção pela atenção e dedicação ao aprendizado de seus alunos.

Aos meus gestores Lucine Coelho, Adriana Duarte, Fernanda Gandur, Roberta Rivaldo, e Magna Santos pelos ensinamentos profissionais e pela colaboração em minha carreira.

Aos amigos do trabalho Jacqueline Almeida, Thalita Lima, Juliana Dalmam, Deise Macedo, Francine Chien, Eduardo Monteiro, Guilherme Stumpf, Valéria Molina, Vera Santos, Sarah Lemos, Aline Simões e Rodrigo Dias, pela ajuda e pelo bom humor, tornando nossa convivência uma experiência enriquecedora do ponto de vista pessoal e profissional.

A todos aqueles que me receberam nas empresas estudadas Paulo Crapina, Gina Araújo, Caetano Jesus, Valéria Miola e Daniela Bozetti pela simpatia e disponibilidade em participar deste trabalho.

A todos meus amigos de sempre, da faculdade, do colégio e da vida, que me acompanharam em todos os momentos, e em especial para quem diretamente esteve presente ao meu lado para realização deste projeto, pela confiança e pelos fantásticos e inesquecíveis momentos de convivência.

Finalmente, a Deus, aos meus pais, aos meus irmãos, a minha cunhada, a meu sobrinho e a minha família por sempre me apoiarem e me incentivarem em todos os momentos de minha vida. 
"Já que sou, o jeito é ser" (Clarice Lispector) 


\section{RESUMO}

O mercado de varejo é reconhecidamente competitivo e dinâmico, exigindo excelência na operação para se obterem bons resultados. É necessário às empresas varejistas adaptar a gestão do negócio à realidade vivenciada, aperfeiçoando o desempenho de processos, com a finalidade de torná-los mais eficazes, eficientes e integrados. O campo acadêmico, por sua vez, vem apresentando número crescente de artigos publicados, relacionados à pesquisa empírica de gestão por processos, como melhoria contínua ou por ruptura, o que revela aumento no interesse pelo tema. Na literatura, há exemplos de melhoria de processos em diferentes setores econômicos como indústria, serviços, educação, saúde, finanças e governo. No entanto, poucos relatos do gênero existem aplicados a empresas de varejo, no Brasil, usando-se abordagem de processos.

Nesse sentido, este trabalho procura contribuir para o desenvolvimento da teoria, podendo servir de base para futuras pesquisas em à melhoria de processos no varejo. A presente pesquisa estuda grandes empresas varejistas brasileiras que possuem área dedicada à melhoria de seus processos, e conseguiu identificar como aquelas organizações definem processos, efetuam seu mapeamento e selecionam aqueles destinados ao aprimoramento. Ademais, este estudo descreve como funciona o planejamento e a organização de atividades para que se efetue melhoria de processos; analisa como aquelas empresas atuam na implementação das melhorias, apontando dificuldades e fatores críticos de sucesso. Por fim, examina-se a maneira pela qual são empregados indicadores que permitam constatar a melhoria dos processos.

A partir de estudo de casos, este trabalho propõe análise qualitativa de três das maiores empresas do varejo brasileiro, no que toca à implementação de melhoria de processos. Foram utilizados métodos de natureza qualitativa na coleta e na análise de dados, a partir de múltiplas fontes de evidência: entrevistas semi-estruturadas com gestores e consultores das áreas concernidas, análise de documentos da empresa além de observação direta e participante da evolução do trabalho ao longo do período estudado.

Dentro de suas limitações, este trabalho revela que, se as grandes empresas de varejo estudadas possuem área dedicada à melhoria contínua de processos, a cultura de processos é, entretanto, recente, seus conceitos sendo aplicados conforme a maturidade da empresa em conhecimentos de qualidade. São processos administrativos e de suporte aqueles geralmente selecionados para melhoria, não estando necessariamente alinhados a objetivos estratégicos da 
empresa, nem ainda relacionados diretamente ao modelo de negócio da organização ou ao cliente final, uma vez que a escolha depende do interesse da área patrocinadora do projeto de melhoria de processos. A área de Processos é reconhecida como responsável por estruturar processos, atuando de forma coordenada e disciplinada, valorizando planejamento antes de execução, sem perder foco no resultado final desejado, promovendo parcerias entre as áreas e sentimento de participação conjunta na implementação do novo processo. As empresas não possuem metodologia comum para melhoria de processos, sendo que cada qual faz adapta metodologias segundo a cultura e a realidade da empresa, somando-se ainda boas práticas de mercado e experiência da equipe. Dentro dos projetos de melhoria, os processos possuem donos formalmente atribuídos, responsáveis por sua execução, podendo ou não ser divulgados para todos os níveis hierárquicos da empresa. Além disso, as empresas vivenciam, cada uma a sua maneira, dificuldades (humanas; tempo e recursos financeiros; técnica, de tecnologia e metodologia; política e gestão) e fatores críticos de sucesso (apoio da alta gestão; alinhamento estratégico; avaliação de desempenho e efeito de demonstração; presença de liderança; uso efetivo de tecnologia de informação; comunicação e transferência de conhecimento; rigor na implementação de melhorias; gestão da mudança em recursos humanos; seleção criteriosa de colaboradores; e concorrência de mercado). Por fim, o uso de indicadores, quando acontece, tem por objetivo criar histórico de dados que permita analisar e avaliar o potencial de melhoria contínua daquele processo, não estando, uma vez mais, formalmente alinhado à perspectiva estratégica da empresa nem o cliente final.

Apesar de relativamente bem encaminhadas, as empresas ainda possuem um caminho a percorrer para atingir maturidade na gestão por processos e buscar melhorar aqueles que agregam valor direto ao cliente final.

Palavras-chave: melhoria de processos; empresas brasileiras; varejo. 
Retail market is said to be highly competitive and dynamic, demanding excellence in the operation in order to obtain good results. Companies from that sector need to adapt the business management to the reality experienced by improving process performance in order to make them more effective, efficient and integrated. As far as the academic production goes, the growing number of published articles related to empirical research of processes management, either continuous or radical improvement, shows an increasing interest in the field research on this subject. The literature provides examples of process improvement in various economic sectors such as manufacturing, services, education, health, finance and government. However, there are few reports on process improvement in Brazilian retail companies using process approach.

In this sense, this paper seeks to contribute to the theory evolution, and it could be a basis for future research related to process improvement and retail. The object of this study are large companies in the Brazilian retail sector that have an area dedicated to the improvement of their processes. This work reached the following objectives: to identify how these companies define processes, how they map their processes and which of these processes are selected to be improved; to describe how they plan and organize activities to make process improvement; to analyze how these companies operate to implement processes improvement, identifying difficulties and critical success factors; in addition, to examine how companies use indicators to put in evidence processes improvement.

From case studies, this paper develops a qualitative analysis of the way three of the largest Brazilian retail companies tackle with process improvement. Qualitative methods to collect and analyze data from multiple sources of evidence were employed: semi-structured interviews with managers and consultants in the concerned areas, analysis of official documents as well as direct and participant observation in the work evolution during the studied period.

Within its limitations, this study reveals that if large retail companies have an area dedicated to processes continuous improvement, the process culture is nonetheless recent and its concepts are applied as maturity of the company in quality.knowledge emerges. It is usually administrative and support processes that are selected for improvement, not necessarily aligned with corporate strategic goals, neither directly related to the business 
model of the organization or the end customer, since the choice depends on the sponsor area interest of that process improvement project. The Process area is recognized as the responsible for structuring processes, acting in a coordinated and disciplined way, highlighting planning before execution, without losing focus on the desired end result, promoting partnerships among other areas and a sense of joint participation in the implementation of new process. The studied companies have no common methodology for improving processes, each of them adapts existing methodologies to the local culture and reality, taking into consideration benchmarking and team experience. Among the improvement projects, processes have formally assigned owners responsible for their implementation, and they may (or not) be disseminated to all hierarchical levels of the company. In addition, companies experience in an idiosincratic way difficulties (human; time and financial resources; technique, technology and methodology; policy and management) and critical success factors (top management support; strategic alignment; performance evaluation and demonstration effect, the presence of leadership; effective use of information technology; communication and knowledge transfer; rigorous on implementation of improvements; change management in human resources; careful selection of employees; and market competition). The use of indicators, if any, aims at creating historical data to analyze and evaluate potential for continuous improvement of that process and they are not, once more, formally aligned neither with the strategic perspective of the company nor related to the final customer.

Although relatively well under way, companies still have some time to reach maturity in process management and to improve processes that add value directly to the final customer.

Palavras-chave: process improvement; Brazilian companies; retail. 


\section{LISTA DE ILUSTRAÇÕES}

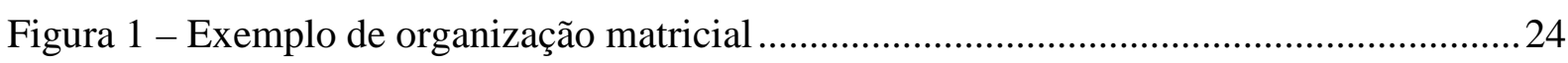

Figura 2 - Operacionalização da pesquisa: condução de estudo de casos .............................. 44

Figura 3 - As etapas para melhoria de processos na empresa A .............................................50

Figura 4 - Os níveis que compõem o estudo de processos na empresa A ...............................50

Figura 5 - Fechamento definitivo de lojas: impacto sobre o negócio e qualidade de

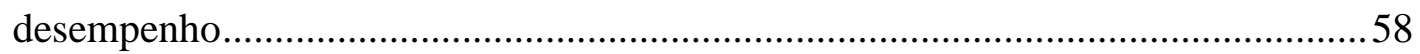

Figura 6 - Fechamento definitivo de lojas: priorização de melhorias......................................59

Figura 7- As etapas do processo de "Distribuição de uniformes" ..........................................73

Figura 8 - As etapas do processo "Solicitação de viagens" .................................................. 77

Figura 9 - As etapas para implantação do sistema na gestão de viagens corporativas ............79

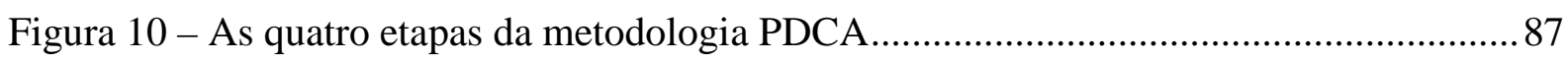

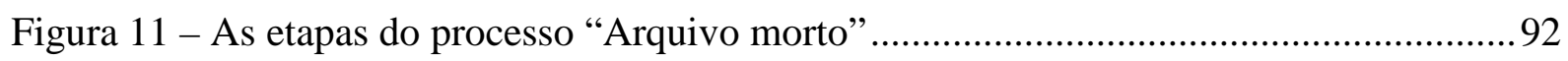

Figura 12 - As etapas do processo "Inventário em loja” .................................................... 97 


\section{LISTA DE TABELAS}

Quadro 1 - As mais populares "melhores práticas" de obter novos desenhos de processos ...33

Quadro 2 - Dificuldades para implementação de melhorias ................................................... 34

Quadro 3 - Fatores críticos de sucesso (FCS) para implementação de melhorias ....................36

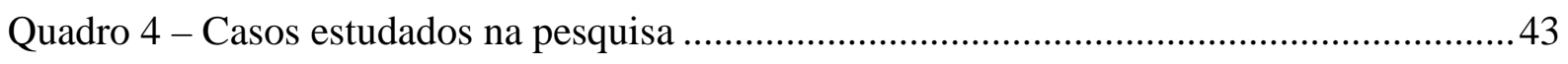

Quadro 5 - Entrevistas realizadas na pesquisa ................................................................. 47

Quadro 6 - Exemplo de projeto de melhoria de processos na empresa A …...........................55

Quadro 7 - Exemplo de melhoria do processo de fechamento definitivo de lojas ..................61

Quadro 8 - Conceitos da literatura e análise do caso A .........................................................62

Quadro 9 - Exemplos de projetos de melhoria de processos na empresa B ...........................69

Quadro 10 - Exemplo de melhoria do processo de distribuição de uniformes .........................75

Quadro 11 - Exemplo de melhoria de processo de gestão de viagens corporativas .................83

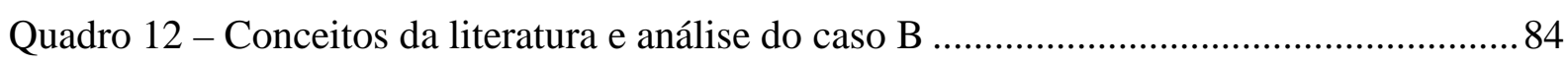

Quadro 13 - Exemplos de projetos de melhoria de processos na empresa C ........................91

Quadro 14 - Exemplo de melhoria de processo de arquivo morto .........................................96

Quadro 15 - Exemplo de melhoria de processo de inventário em loja ................................. 103

Quadro 16 - Conceitos da literatura e análise do caso C .................................................... 104 


\section{SUMÁRIO}

1 INTRODUÇÃO

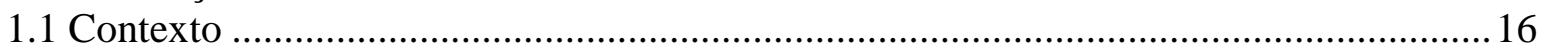

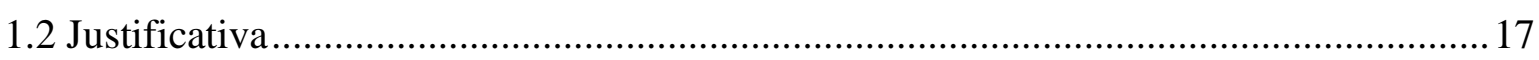

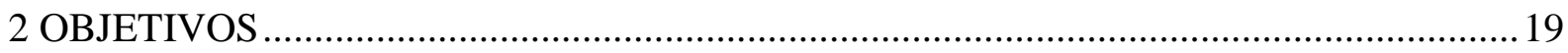

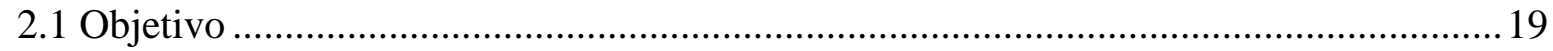

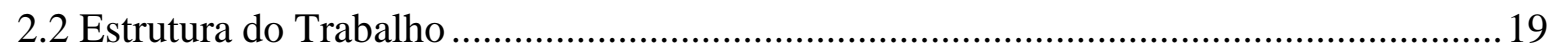

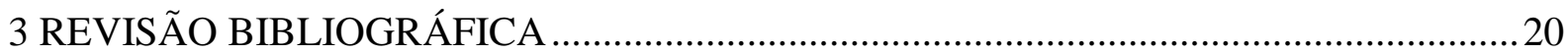

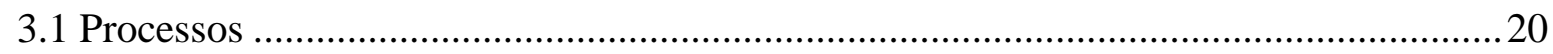

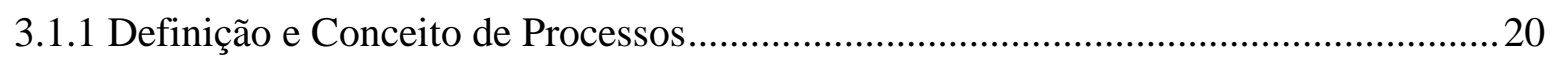

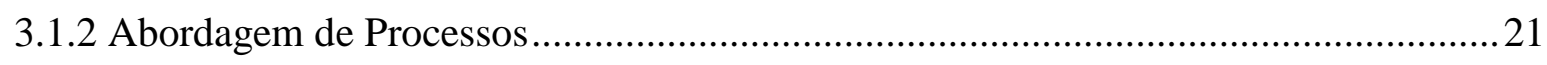

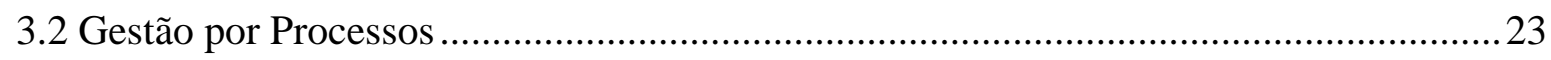

3.2.1 Definiçãa e Conceito de Gestão por Processos ..........................................................23

3.2.2 Gestão por Processos e Organização das Empresas .....................................................24

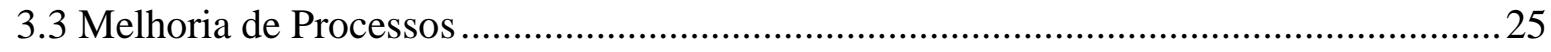

3.3.1 Definição e Conceito de Melhoria de Processos ........................................................25

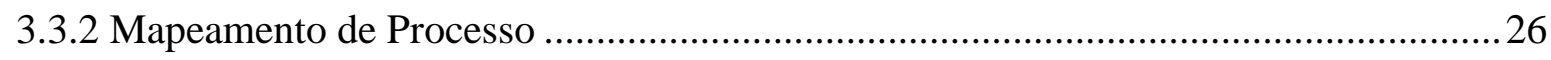

3.3.2.1 Relevância de Mapeamento para Melhoria de Processos........................................26

3.3.2.2 Elaboração de Desenho de Processos ....................................................................2

3.3.2.3 Benefícios e Resultados de Mapeamento de Processos..........................................28

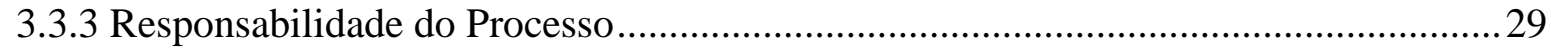

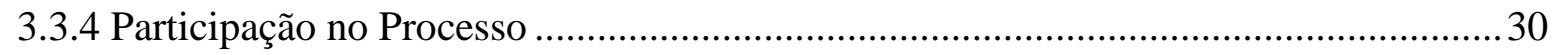

3.4 Implementação de Melhoria de Processos ................................................................. 31

3.4.1 Contexto Organizacional e Metodologia de Melhoria de Processos .......................... 31

3.4.2 Abordagem de Metodologias de Melhoria de Processos............................................33

3.4.3 Dificuldades de Implementação de Melhoria de Processos ........................................34

3.4.5 Fatores Críticos de Sucesso de Implementação de Melhorias de Processos ................35

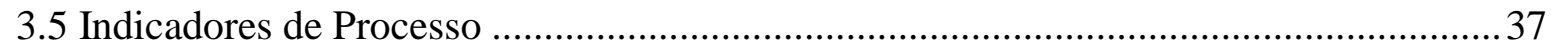

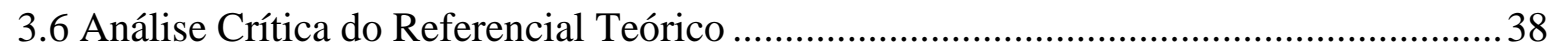

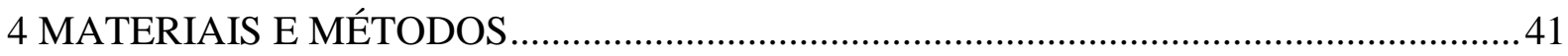

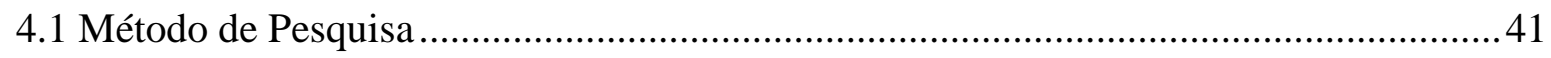

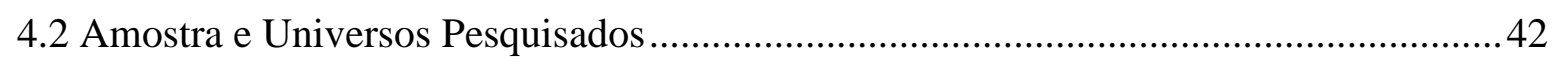

4.3 Planejamento e Operacionalização de Pesquisa .......................................................... 44

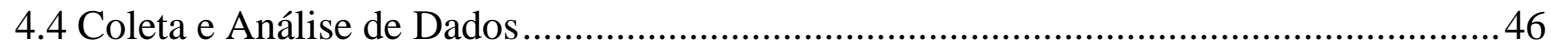




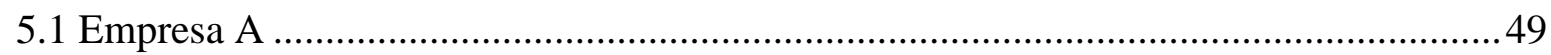

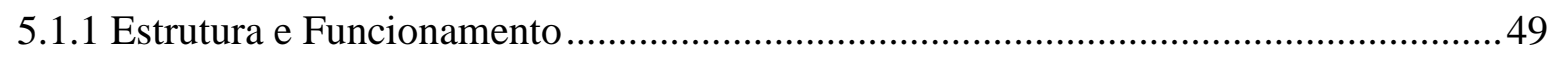

5.1.2 Metodologia para Melhoria de Processos............................................................. 49

5.1.3 Atuação para Abordagem de Processos....................................................................50

5.1.4 Exemplo de Projeto de Melhoria de Processos ..........................................................54

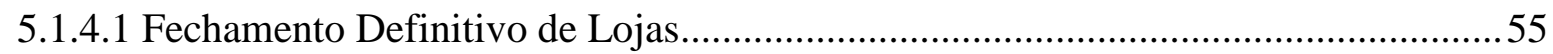

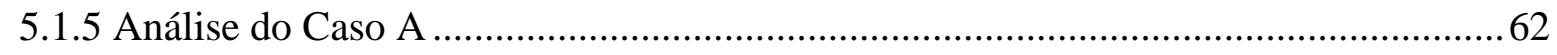

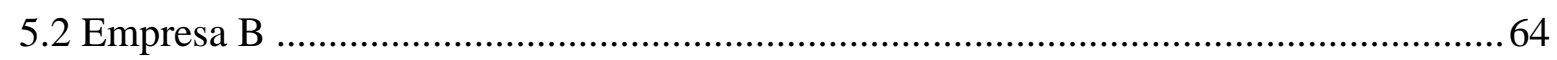

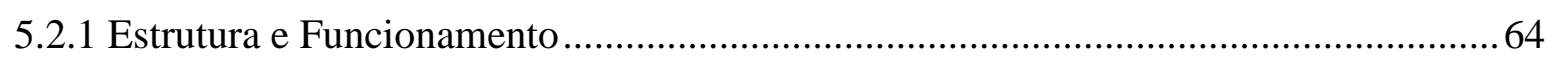

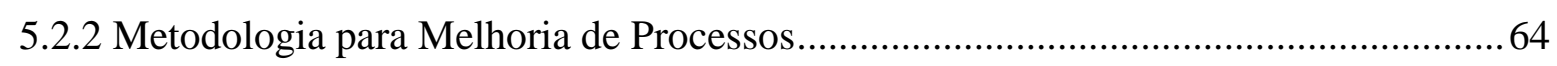

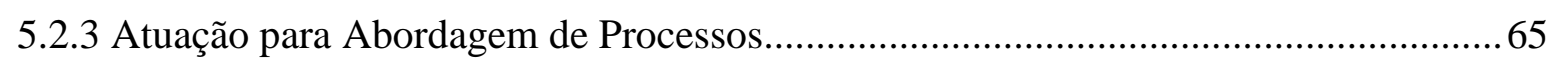

5.2.4 Exemplo de Projeto de Melhoria de Processos ...........................................................68

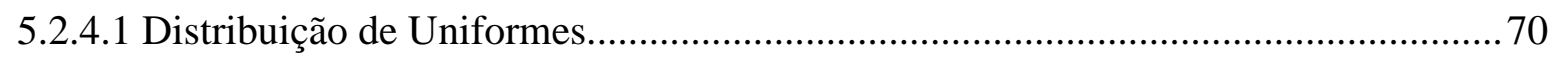

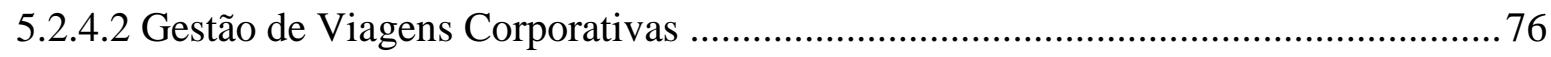

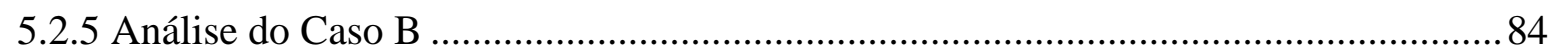

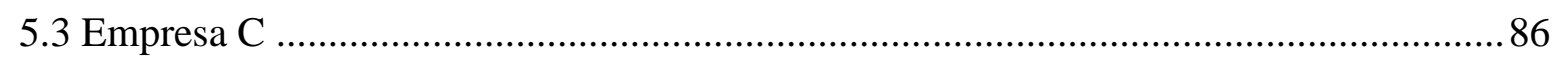

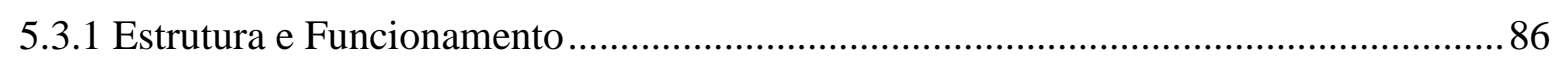

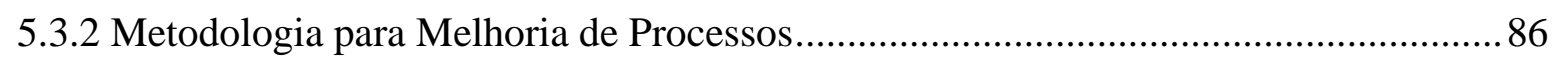

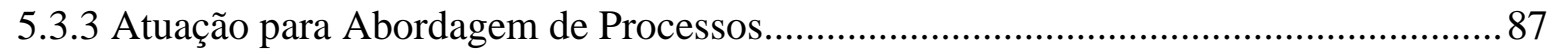

5.3.4 Exemplo de Projeto de Melhoria de Processos .................................................................90

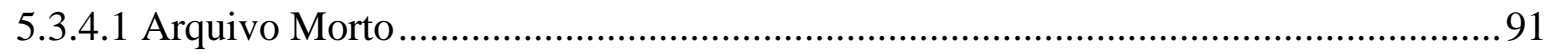

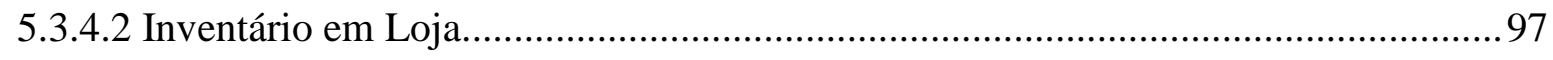

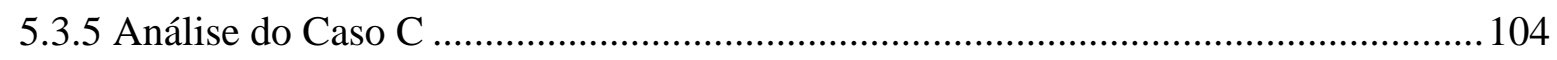

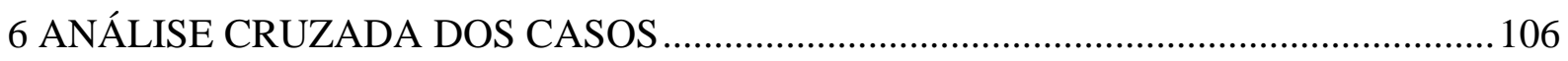

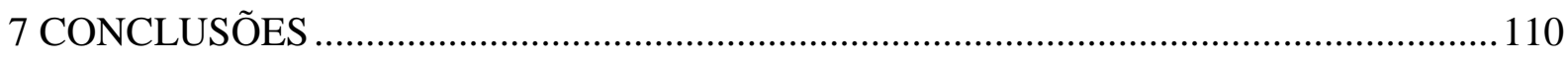

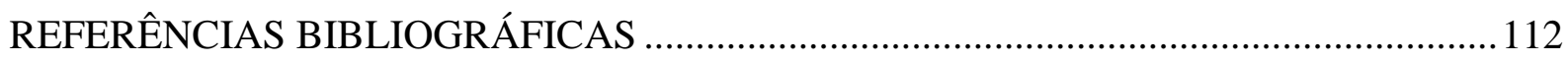

APÊNDICE A - QUESTIONÁRIO DE PESQUISA …................................................... 122

APÊNDICE B - CONSOLIDADO PARA ANÁLISE CRUZADA DOS CASOS ................ 127 


\section{INTRODUÇÃ̃o}

\subsection{Contexto}

O varejo assume cada vez mais papel de destaque na economia do Brasil. Fazendo parte de um mercado extremamente competitivo, as instituições varejistas oferecem diversos produtos e serviços para satisfazer às necessidades dos consumidores.

Segundo Parente (2000), as empresas que operam no Brasil apresentam variedade muito completa de modelos e formatos de lojas: alimentício (bares, padarias, supermercados, hipermercados, clubes atacadistas, etc.), não alimentício (lojas especializadas, lojas de departamento, etc.) e serviços (salões de beleza, clínica médica, academia de ginástica, etc.).

$\mathrm{Na}$ medida em que, para obter bons resultados, as instituições varejistas buscam excelência na operação, necessitam, ao mesmo tempo, adaptar a gestão do negócio à realidade vivenciada. Esta adequação implica no aperfeiçoamento do desempenho de processos, a fim de torná-los mais eficazes, eficientes e integrados. Conforme Sidorova e Isik (2010), essa necessidade obriga a adoção de abordagem de processos por parte das empresas, no que diz respeito ao gerenciamento de suas operações.

De forma geral, o varejo é considerado setor bastante dinâmico que exige resultados em curto prazo, requerendo improvisação e tomada de decisão rápida frente à atuação da concorrência. Por conseguinte, muitas vezes faz-se uso da intuição em detrimento ao planejamento rígido de atividades. O conhecimento e experiência do negócio prevalecem em busca de atingir os objetivos da empresa. O desdobramento desta forma de atuação implica nas empresas daquele setor estarem em fase embrionária de cultura e abordagem estruturada baseada em gestão por processos.

Ao longo dos anos, a gestão por processos, associada ao conceito de qualidade (AHIRE; DREYFUS, 2000), cresceu em importância para a indústria. O mesmo começa a se verificar progressivamente no setor de serviços, sobretudo nas áreas de saúde, finanças, governo e varejo (GEORGE, 2003; HOUY et al.,2010).

$\mathrm{Na}$ literatura de gestão de operações, o conceito de gestão por processos é abordado tanto como melhoria contínua quanto como melhoria por ruptura, caso em que há inserção de processos totalmente novos. Para ambos os casos, a gestão realizada é orientada para 
processos com a finalidade de agregar valor ao cliente (LIN et al.,2002; GOLDKUHL; LIND, 2008; DOOMUN; JUNGUM, 2008; PAIM et al., 2008).

Uma vez compreendidas e gerenciadas as atividades segundo abordagem de processos, é fundamental buscar a melhoria e a otimização dos mesmos. Segundo Rummler e Brache (1992), não melhorar o desempenho do processo implica não melhorar o desempenho da organização; não gerenciar os processos de maneira efetiva significa não gerenciar efetivamente os negócios.

\subsection{Justificativa}

A partir de estudo em amostra de 355 artigos da literatura, Houy et al. (2010) afirmam que há um número crescente de artigos publicados relacionados à pesquisa empírica de gestão por processos o que mostra um aumento no interesse pela pesquisa de campo neste assunto.

Para Neubauer (2009), a gestão por processos está entre os mais importantes tópicos de gerenciamento porque permite às empresas adaptação ágil às mudanças de requisitos do negócio em função da concorrência, pressão de custos, dentre outros fatores. Esta abordagem estruturada (AL-MUDIMIGH, 2007) permite entender, analisar, suportar e melhorar continuamente processos fundamentais da operação de uma empresa.

Neste contexto, Küng e Hagen (2007) mostram em sua pesquisa que através da aplicação da gestão por processos, a qualidade e o desempenho dos processos aumentam substancialmente. Eles destacam como principais efeitos a diminuição do tempo de ciclo, o aumento de produção por colaborador e o aumento da qualidade dos produtos. Além disso, eles afirmam que a gestão por processos permite maior visibilidade da estrutura dos processos para os colaboradores e melhoria da qualidade dos processos tornando mais claro os papéis, deveres e responsabilidades dos participantes.

Orientação voltada a processos é extremamente importante para o sucesso dos esforços de gestão por processos dentro das empresas (REIJERS, 2006). De acordo com Škrinjar et al. (2008), embora a literatura apresente abundante oferta de benefícios da orientação voltada a processos, a sua confirmação empírica é escassa. Recentemente, foram desenvolvidos poucos estudos empíricos relacionando desempenho organizacional com melhoria obtida a partir da adoção de práticas de gestão por processos e orientação voltada a processos, ou ainda, conforme Palmberg (2010), poucos estudos empíricos relacionando questões organizacionais 
ao implementar gestão por processos, por exemplo, como lidar com a relação entre organização funcional e a perspectiva de processo e os papéis dos gestores, equipes e indivíduos.

Diversos autores (KLASSEN; MENOR, 2007; KUMAR et al., 2010; MANSAR, REIJERS, 2007; SENTANIN et al., 2008; PAIM et al. 2008) atentam, em suas recentes pesquisas, para a necessidade de estudos sobre a própria abordagem de processos, assim como sobre a melhoria de processos. Na última década, diversas técnicas e ferramentas têm sido utilizadas para acelerar e melhorar processos (CHAN; SPEDDING, 2003; MACINTOSH, 2003).

Muitos pesquisadores e empresas acreditam que repensar e redesenhar processos são tendências para obter melhorias reais e sustentáveis para o negócio (REVERE, 2004). Na literatura, há exemplos de melhoria de processos em diferentes setores econômicos como o industrial (LEE; CHUAH, 2001), o de serviços (DOOMUN; JUNGUM, 2008), o educacional (AHMAD et al., 2007) e o financeiro (KÜNG; HAGEN, 2007; TERZIOVSKI et al., 2003).

Apesar dos diversos pontos em comum entre também diversas propostas, existe a necessidade de adaptá-las conforme área de atuação da empresa (AL-HUDHAIF, 2009; JULIEN; TJAHJONO, 2009), justificando-se, portanto a importância de se desenvolver metodologia específica para cada setor.

Especificamente para empresas de varejo, Tax e Stuart (1997) incentivam em seu artigo a realização de pesquisas que investiguem os impactos de diferentes formas de novos serviços, dentre eles a reengenharia de processos, ocasionando mudanças que atingem a forma de trabalho das empresas deste setor.

A importância do aperfeiçoamento de processos e da melhoria contínua no varejo é tema de pesquisas (DALE, 1994; KUMAR, 2005), mas não há necessariamente modelos estruturados para práticas como mapeamento de processos, diagnóstico de oportunidades ou implementação de melhorias.

Por fim, Grewal e Levy (2007), a partir de sua revisão da literatura pelo periódico Jounal of Retailing, no período de 2002 a 2007, sugerem uma série de questões de pesquisa que, uma vez respondidas, poderiam aperfeiçoar processos no varejo. A abordagem voltada a processos possibilita maior entendimento dos assuntos apontados pelos referidos autores.

Uma vez que existem poucos relatos na literatura sobre melhoria de processos em empresas de varejo no Brasil usando abordagem de processos, justifica-se o estudo de tais casos a partir do contexto de atuação de tais empresas. 


\section{OBJETIVOS}

\subsection{Objetivo}

Este trabalho tem como objeto de estudo grandes empresas de varejo no Brasil que possuem área dedicada à melhoria de processos. Pretende-se alcançar os seguintes objetivos:

- identificar como estas empresas definem processos, efetuam mapeamento dos mesmos e quais destes são selecionados para serem melhorados;

- descrever como funciona o planejamento e a organização de atividades para efetuar melhoria de processos;

- analisar como estas empresas atuam para implementar melhoria de processos, identificando dificuldades e fatores críticos de sucesso;

- examinar como estas empresas utilizam indicadores para constatar a melhoria dos processos.

\subsection{Estrutura do Trabalho}

Estruturado em sete tópicos, o trabalho apresenta, em seus dois primeiros, introdução com conceitos relacionados ao tema e objetivos da pesquisa. Em seguida, no terceiro capítulo, há levantamento da literatura de processos, gestão por processos, melhoria de processos e utilização de indicadores, destacando também dificuldades e fatores críticos de sucesso para implementação de melhoria de processos. No quarto capítulo explica-se o método de pesquisa e no capítulo seguinte apresentam-se os casos de empresas de varejo de grande porte no Brasil que aplicam conceitos de melhoria de processos. As unidades de análise são as empresas, sendo foco de estudo a metodologia utilizada para melhoria de processos. Finalmente, no sexto capítulo, realiza-se análise cruzada dos casos, identificando pontos em comum e divergências consideradas ao utilizar método estruturado de melhoria de processos naquelas empresas. No último capítulo temos as conclusões do estudo além de limitações e proposta de futuras pesquisas. Os produtos deste trabalho - estudo de casos e conclusões obtidas a partir das análises dos mesmos - são relevantes para futuros trabalhos a serem desenvolvidos relacionados a varejo assim como para consultores de processos de empresas deste setor. 


\section{REVISÃO BIBLIOGRÁFICA}

Para estabelecer base teórica para o trabalho, verificar estado da arte no tema estudado e identificar lacunas de pesquisa, este referencial teórico apresenta conceitos gerais e específicos do tema em questão. Diante disso, o autor destaca o conceito de processos, gestão por processos e melhoria de processos. Enfatiza-se também pontos que influenciam a melhoria de processos como contexto organizacional, a importância de mapeamento, desenho, atribuição de dono e participação dos envolvidos no processo. Além disso, ao invés de apresentar as ferramentas da qualidade, o foco do referencial teórico é discutir a abordagem das metodologias de melhoria de processos. Em seguida, são apresentadas dificuldades, fatores críticos de sucesso para implementação de melhoria de processo e a importância de uso de indicadores para monitoramento de processos. Por fim, realiza-se análise crítica da literatura destacando principais pontos dos conceitos envolvidos e limitações que permitem a formulação de pergunta de pesquisa associada ao objetivo do trabalho.

\subsection{Processos}

\subsubsection{Definição e Conceito de Processos}

Processo é basicamente entendido como sequência organizada de atividades que transforma entradas de fornecedores em saídas para clientes, de maneira que a unidade resultante contenha valor agregado (ROTONDARO,1998). Essas atividades devem apresentar relação dita "lógica" entre si, com a finalidade de atender e, preferencialmente, suplantar necessidades e expectativas de clientes externos e internos da empresa (OLIVEIRA, 2006). Neste sentido, mesmo atendendo clientes externos e internos, o processo deve sempre ter visão do cliente final. Portanto, é para ele que as atividades do processo devem agregar valor direta (através de clientes externos) ou indiretamente (através de clientes internos). Conforme Rotondaro (2006a), podemos, resumir processo como conjunto de atividades do início ao fim, que juntas, criam valor para o cliente final. 
Este trabalho não tem objetivo de esgotar os conceitos e definições de processo. No entanto, são relatadas a seguir as seguintes definições de processos importantes de serem descritas: processos de trabalho, processos de negócio e processos-chave ou críticos.

De acordo com Garvin (2002), processos de trabalho são sequiências de atividades que transformam inputs em outputs contemplando processos operacionais (processos que criam, produzem e fornecem bens ou serviços que os clientes desejam, ou seja, processos relacionados às atividades-fim) e processos administrativos (processos que dão suporte à realização de processos operacionais).

Mais especificamente, processos de negócio são macro processos ligados ao modelo de negócio da organização. De acordo com Hammer (2002) é um grupo organizado de atividades relacionadas que atuam juntas na criação de resultado de valor para os clientes. Este mesmo autor enfatiza os termos organizado e juntas, pois todas as atividades devem trabalhar em conjunto, alinhadas no comum propósito de servir às necessidades de clientes. Por sua vez, Al-Mudimigh (2007) complementa esta definição afirmando que os processos de negócio são simplesmente o modo que o trabalho é feito em qualquer empresa passando por todas suas funções, desde o pedido realizado pelo cliente até a entrega do produto ou serviço.

Finalmente, processos-chave ou críticos é conjunto de processos necessários e suficientes para satisfazer as variáveis críticas de sucesso que permitem à organização perseguir e realizar os objetivos estratégicos de referência (ROTONDARO,2006b). Seus resultados produzem alto impacto para os clientes e são fundamentais para implementação da estratégia da empresa.

\subsubsection{Abordagem de Processos}

Orientação para processos e percepção da organização como cadeia de atividades interligadas por departamentos, trouxeram resposta poderosa para problemas enfrentados por organizações estruturadas por função e orientadas para produtos (GARVIN, 1998).

A orientação voltada para processos busca eficiência organizacional e rapidez, foca em atividades geradoras de valor para clientes e questiona aquelas que não contribuam diretamente neste objetivo (DAVENPORT, 1993). Ela conduz empresa indiretamente a melhores resultados financeiros e torna-se vantajosa desde que tenha influência positiva no desempenho organizacional. Lacerda (2010) afirma que abordagem de processos melhora 
análise de atividades seqüenciais, permitindo entendimento holístico e melhoria da empresa como um todo. Por sua vez, Kohlbacher (2010) faz uma revisão da literatura recente em 26 artigos e mostra como principais efeitos da orientação para processos no desempenho organizacional a melhoria de rapidez na execução do processo, aumento da satisfação dos clientes, melhoria de qualidade, redução de custos e melhoria de desempenho financeiro. Quanto mais a empresa é orientada para processos, melhor seu desempenho tanto em perspectiva global como a partir da perspectiva dos trabalhadores (ŠKRINJAR et al., 2008).

Kumar et al. (2010) por sua vez mostra em seu artigo que orientação para processos reduz significativamente desafios e tem efeito positivo na implementação bem sucedida de sistemas em empresas (por exemplo, chamados sistemas ERP - enterprise resource planning).

Para efetiva compreensão da maneira como é realizado o trabalho, Rotondaro (2006a) reforça que a empresa deve ser orientada para processos, ao invés de tarefas. Quando o foco é o processo, é necessária a união de propósitos na busca de meta comum, o que demanda gerenciamento holístico, ao invés de foco no resultado de departamento específico.

A orientação para processos implica que o procedimento de fazer tarefas em empresas deve ser mais cooperativo e integrado com a finalidade de satisfazer as necessidades dos clientes (KUMAR et al, 2010).

Torna-se evidente que todas as empresas são compostas de processos, mesmo que elas não tenham adotado a gestão por processos. Portanto, a abordagem de processos pode ser aplicada para qualquer empresa e o nível da orientação para processos pode ser determinado em relação ao desempenho do negócio (ŠKRINJAR et al., 2008).

Neste sentido, os processos devem estar direta ou indiretamente relacionados aos objetivos da empresa, e portanto, não há razão de existir processos sem conexão alguma ao planejamento estratégico de negócios, uma vez que são consumidores de recursos e desorganizam outros processos (SENTANIN et al., 2008).

Finalmente, um processo tem um ciclo de vida que é avaliado pela extensão a qual os processos são explicitadamente definidos, gerenciados, medidos e controlados. Uma vez que maiores níveis de maturidade de orientação voltada para processos levam a melhores desempenhos organizacionais, os gestores precisam examinar suas práticas, estruturas, gestão e medição dos processos avaliando seu estado atual (ŠKRINJAR et al., 2008). Destaca-se assim a gestão por processos como ferramenta para executar este papel de administrar, avaliar, medir e melhorar os processos da empresa. 


\subsection{Gestão por Processos}

\subsubsection{Definição e Conceito de Gestão por Processos}

A gestão por processos tem sido utilizada com sucesso como conceito para melhoria organizacional tanto na rede pública (BIAZZI,2007; GULLEDGE; SOMMER,2002; HESSON et al. 2007; PEIXOTO, 2006; SENTANIN et al.,2008) quanto em empresas privadas (CLIMENT et al. 2009; KAMHAWI, 2008; KÜNG; HAGEN,2007; PAPER et al., 2002; SHIN; JEMELLA, 2002). Em geral, gestão de processos tem origem em duas gênesis da literatura: gestão da qualidade e gestão por ruptura. Estes conceitos serão desenvolvidos na seção “3.3.1”.

A gestão por processos suporta os processos usando métodos, técnicas e software para desenhar, controlar e analisar processos operacionais envolvendo pessoas, organizações, documentos e outras fontes de informação (VAN DER AALST, 2004).

Podemos definir gestão por processos como metodologia para avaliação contínua, análise e melhoria do desempenho dos processos que mais impacto exerçam na satisfação de clientes e acionistas (envolvidos em processos-chave), o que possibilita o desenvolvimento e a implementação de mudanças benéficas e sustentáveis para o desempenho do processo (HAMMER, 1994 apud ROTONDARO, 2006a).

Palmberg (2009) indica, a partir de pesquisa em 77 artigos, que não há definições comuns do conceito de gestão por processos, mas existem dois movimentos diferentes a respeito desta definição. Um deles, focado na gestão e melhoria de um único processo, pode ser resumido como abordagem estruturada para analisar e melhorar continuamente o processo, enquanto o outro movimento compartilha visão mais holística da gestão por processos como parte de gestão da empresa como um todo e pode ser definido como maneira mais holística de gerir todos aspectos do negócio sendo perspectiva valiosa a ser adotada ao determinar a eficiência organizacional.

Desta maneira, gestão por processos pode ser encarada como metodologia que viabiliza melhorias em processos, a partir de abordagens estruturadas. Em suma, a gestão por processos possibilita o desenvolvimento e melhoria continua das estratégias corporativas e permite às empresas concentrarem-se nos processos que geram valor (NEUBAUER,2009). 


\subsubsection{Gestão por Processos e Organização das Empresas}

Muitas empresas apresentam estrutura hierárquica departamental verticalizada em que cada área está focada na execução de suas próprias tarefas. Para a organização, isto resulta em objetivos estabelecidos de maneira independente para cada função. Por conseguinte, quando a área busca melhor desempenho de atuação, não necessariamente resulta na otimização da organização como um todo, uma vez que existe relação entre os processos executados pelos departamentos.

Em contra partida a esta visão, segundo Rotondaro (2006a), a gestão por processos possibilita a análise da organização como sistema integrado, em que o trabalho é executado através de seus processos; sua finalidade é fazer com que as atividades sejam vistas não em termos de funções, departamentos ou produtos, mas de processos-chave dentro da empresa.

Assim, a empresa pode ter visão horizontal do negócio, atentando-se para os relacionamentos internos entre cliente e fornecedor, por meio dos quais são produzidos produtos e serviços. Ao conciliar a estrutura departamental verticalizada com a abordagem de processos, o resultado é uma organização matricial em que colaboradores possuem gestores funcionais da área técnica - vertical - e gestores do processo em que participa - horizontal. Isto pode ser representado conforme a figura seguinte:

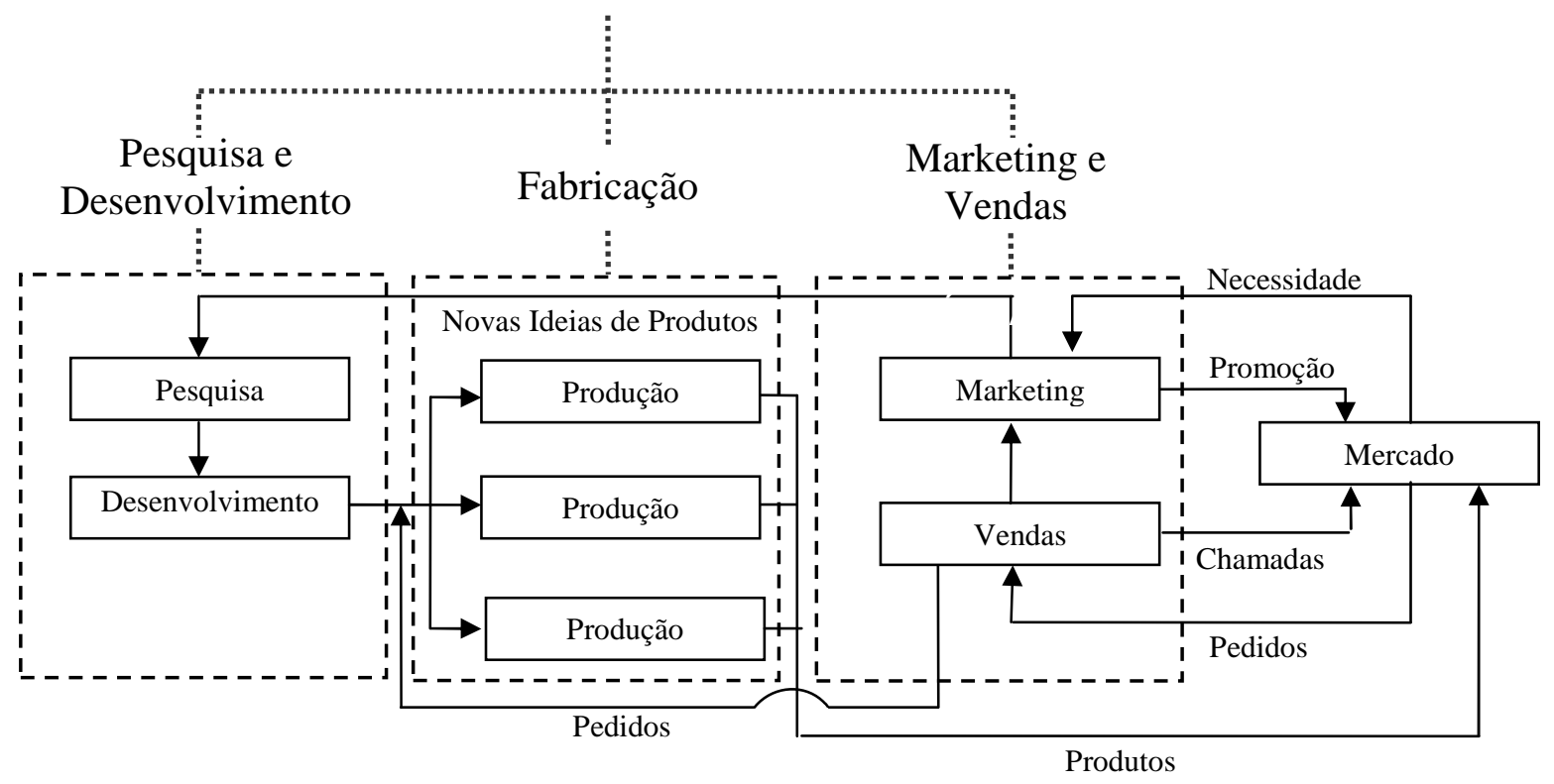

Figura 1 - Exemplo de organização matricial

Fonte: Adaptado de (RUMMLER; BRACHE, 1992) 
Portanto, a gestão por processos bem sucedida necessita equipe organizada com objetivo de analisar, desenhar, implementar e otimizar continuamente processos conforme a estratégia do negócio (NEUBAUER,2009). No entanto, a ligação entre processos fundamentais e a estratégia da empresa geralmente é dificultada porque a gestão por processos necessita de preparação e definição de ações, apoio da alta gestão, competência para mudanças e estratégia para diminuir resistências (GROVER et al., 1995). Desta forma, para se melhorar o desempenho da organização, é fundamental haver estudo de melhoria dos processos, ou seja, gestão efetiva dos processos, o que significa gestão eficaz do negócio como um todo.

\subsection{Melhoria de Processos}

\subsubsection{Definição e Conceito de Melhoria de Processos}

Métodos e técnicas para melhoria de processos são apresentados em obras tradicionais da literatura (DAVENPORT,1993; HAMMER; CHAMPY, 1993; RUMMLER; BRACHE, 1992) assim como são alvo de estudos recentes de pesquisadores (ADESOLA; BAINES, 2005; DAMIJ et al., 2008; KLEIN; PETTI, 2006; MANSAR; REIJERS, 2007).

A melhoria de processos é uma abordagem estruturada para analisar e aperfeiçoar continuamente atividades fundamentais da operação de uma empresa através da simplificação de processos melhorando eficiência, eficácia e adaptabilidade (LEE; CHUAH, 2001) e proporcionando aumento de competitividade (DAMIJ, 2007).

Desde a segunda metade do século 20, as empresas têm sido pressionadas a melhorarem seu desempenho em larga escala e portanto a buscarem melhoria de processos. Em geral, este movimento foi acompanhado por duas gênesis (HECKL et al., 2010). Primeiro, a competição globalizada e os produtos com menores ciclos de vida demandam mudanças bruscas forçando as empresas a desenvolverem novos processos orientados a clientes e redesenhar aqueles existentes (HECKL; MOORMANN, 2007). Um dos métodos mais radicais foi a reengenharia de processos que prometia alcançar melhorias de ruptura em medidas críticas de desempenho, como custo, qualidade e velocidade (HAMMER; CHAMPY, 1993; WU, 2002). A outra gênese seria de abordagens evolutivas - nomeadamente Gestão da Qualidade Total (Total Quality Management - TQM), Lean Production, Kaizen e Six Sigma - focadas na melhoria 
incremental contínua de processos existentes. Este trabalho não tem como objetivo descrever explicitamente cada uma destas abordagens e, portanto apenas as citaremos quando necessário. Vale ressaltar apenas que a metodologia incremental simplifica e elimina atividades que não agregam valor, melhorando a realocação de recursos (VALIRIS; GLYKAS, 1999).

Todavia, existe na literatura certa confusão considerando o uso de termos como reengenharia, redesenho e melhoria contínua de processos (HESSON et al., 2007). Para este autor, reengenharia é sinônimo de mudança radical e melhoria contínua de processos é sinônimo de mudança incremental. Ambas, reengenharia e melhoria contínua de processos estão inclusas na definição de redesenho.

No entanto, a reengenharia de processos é considerada obsoleta e impraticável considerando sua visão radical de redesenho, abordagem hierárquica impositiva de cima para baixo, forte foco em automatização de processos e histórico anterior de falhas e problemas. Outras abordagens como o desenho e redesenho de processo, a melhoria de processo, etc. ainda estão vivas e amplamente utilizadas por vários consultores e profissionais, freqüentemente sob nomes diferentes (SEETHAMRAJU; MARJANOVIC, 2009).

\subsubsection{Mapeamento de Processo}

\subsubsection{Relevância de Mapeamento para Melhoria de Processos}

Antes de um processo ser melhorado, é necessário ter uma imagem detalhada e precisa de como o processo está funcionando atualmente, incluindo suas forças e fraquezas (DONNER et al., 2001). Todas atividades de um processo devem ser direcionadas por desenho que as discrimine, bem como aponte quando e quem deverá executá-las (HAMMER, 2002). É indispensável que empresa esteja empenhada em obtê-los suficientemente documentados.

Algumas empresas possuem procedimentos e processos documentados em "Procedimentos Operacionais Padrões (POP)", enquanto que outras confiam somente na experiência de seus colaboradores. Apesar de isso ser suficiente no passado, atualmente o entendimento de processos na maioria das vezes necessita algo mais: uma representação gráfica através de fluxo (ŽABJEK et al., 2009). De acordo com Aguilar-Saven (2003) fluxos 
são construídos para oferecer uma compreensão melhor do processo, sendo requisito para melhoria de processos.

O mapeamento de processos, também chamado de desenho de processos, baseado em diagrama de fluxo é ferramenta muito bem conhecida para modelar qualquer sistema de negócio (HINER; RICH, 1997) oferecendo ajuda visual para sua melhoria e provendo meios de análise. Tal estrutura apresenta as relações entre atividades, pessoas, dados e objetivos (SIHA et al., 2008) identificando para cada processo, primário ou de suporte, o cliente (interno e/ou externo), a saída, os recursos - inclusive aqueles imateriais - , os aspectos que devam ser objeto de algum tipo de controle, as ligações e as relações que nutre ele com outros processos, e como aquele é afetado por estes (CARMIGNANI, 2008).

De acordo com Julien e Tjahjono (2009), o mapeamento de processos cria entendimento aprofundado das atividades no processo. O resultado é um desenho que pode ser usado como descrição das atividades no processo: um padrão ou procedimento para reduzir variações em operações. Um outro importante resultado é uma lista de áreas para melhoria. O processo de criação do desenho ajuda os colaboradores a questionarem procedimentos normais e torna possível identificar desperdícios em procedimentos atuais.

Além disso, a interação entre os processos e a organização deve ser visualizada e o desempenho de cada processo deve ser medido em relação aos resultados planejados e esperados (TSIM et al., 2002)

Hammer (2002) afirma ainda que, um processo, tendo sido desenhado para o alcance de certo desempenho, não poderá produzir resultados superiores, a despeito de trabalho árduo por parte dos colaboradores. A seu ver, a empresa atinge o sucesso a partir do desempenho efetivo de processos bem documentados.

\subsubsection{Elaboração de Desenho de Processos}

Tam et al. (2001) definem a modelagem de processos como a construção de atividades funcionais de toda ou parte da empresa para obter a situação atual (As Is) ou a situação proposta $(\mathrm{To} \mathrm{Be})$.

Dependendo do nível de abstração, os processos podem ser descritos em diferentes graus de detalhe para analisar a empresa. Assim os modelos de processos podem ser usados para incentivar a aprendizagem, suportar tomada de decisão ou até desenvolver software 
relacionados. O desenvolvimento de modelagem de processos será mais eficaz se uma finalidade específica é considerada. Isto é motivado pela idéia de que os processos ligados a uma empresa definem a maneira em que os objetivos da empresa podem ser alcançados ou como estes objetivos afetarão os subprocessos da companhia (AGUILAR-SAVEN,2003).

Baldwin et al. (2005) reforça que na maioria dos processos, o estágio de mapeamento de um processo é um momento importante a considerar para implementar um novo sistema ou redesenhar um processo. Isto pode envolver dois níveis de representação: um de mais alto nível para representar as principais fases de um processo especifico, e um nível inferior para representar os níveis operacionais da empresa.

Brocke et al. (2010) reforça ainda que o mapeamento de processos deve trazer ainda informações relevantes (prazo, custos e benefícios tangíveis e intangíveis de possíveis mudanças) para tomada de decisões.

Ungson e Walsh (1991) afirmam que as questões "quem, o que, quando, onde, por que e como" provêm maneira útil de caracterizar o escopo de informação que pode ser adquirida sobre um estímulo de decisão e resposta organizacional específicos. Para responder estas questões é imprescindível que o responsável pelo mapeamento acompanhe pessoalmente o processo entrevistando as pessoas que executam as atividades. Para isso, conforme Berente $e t$ al. (2009), ao elaborar o desenho do fluxo, é importante entender o papel da documentação em um processo, e portanto, antes de especificar um exemplo em um processo, os envolvidos devem compreender o uso real da informação, sua relevância, e seu destino.

\subsubsection{Benefícios e Resultados de Mapeamento de Processos}

O mapeamento de processos é poderosa ferramenta para melhoria de eficiência, pois pode revelar gargalos, utilização improdutiva de recursos, etapas redundantes, atividades que não adicionam valor, e oportunidades de melhoria para o negócio (KELLER; JACKA, 1999; KÜNG; HAGEN, 2007; PARADISO, 2003; SAVORY; OLSON, 2001).

Dentre alguns benefícios, de acordo com Julien e Tjahjono (2009), mapeamento de processos aumenta compreensão e expectativas dos clientes internos, criando entendimento de como se ajudar mutuamente e proporcionar melhores serviços. 
O mapeamento de processos representa graficamente as atividades do processo, disciplina o pensamento contribuindo para desenvolvimento de uma linha de raciocínio, e é elemento chave na melhoria de processos (HARMON, 2007).

A modelagem de processos auxilia a descrever os importantes aspectos de uma empresa, envolvendo pessoas, departamentos e suas interações, representando graficamente estas características. (CLIMENT et al., 2009)

Barber et al. (2003) indica que a modelagem de processos facilita o aprendizado dos colaboradores da empresa. Uma vez que o desenho suporta a gestão por processos fornecendo estrutura estática, há contribuição para a melhoria do processo de aprendizado através de uma perspectiva holística (termo do grego holos que significa todo) em relação a como os processos se encaixam.

Carmignani (2008) afirma que o mapeamento deve ter definição pontual de atividades, recursos utilizados, entradas e saídas, e metas a serem atingidas pelos indicadores de desempenho. A conseqüência disso será mapeamento de processos permitindo analisar, visualizar e saber o curso dos processos de uma empresa, identificando a interação entre os diferentes processos, tomando conhecimento de seus objetivos, requisitos e nível de satisfação; e resultado objetivo planejado por meio do desdobramento do objetivo dentro dos processos identificados e por meio de indicadores fixados.

\subsubsection{Responsabilidade do Processo}

Uma vez estabelecido e desenhado o processo, é fundamental designar-lhe um dono. Grande número de pesquisadores mostram que as empresas estão cientes da importância de definir donos do processo. Nos casos em que os donos de processo ainda não foram definidos, as empresas têm a pretensão de fazê-lo no futuro (ZAIRI; SINCLAIR, 1995).

Hammer (2002) destaca como uma das funções deste profissional garantir que as pessoas entendam o processo executado, sejam nele treinadas, disponham das ferramentas necessárias e sigam o mapeamento especificado no processo.

O dono do processo fica responsável por ajustes mínimos, como correções de pequenos imprevistos, e por direcionar questões evidentes que despontem no desenrolar do processo. Ele é um dos responsáveis por monitorar e controlar os principais indicadores envolvidos, cabendo ainda gerenciar eventuais mudanças no momento em que o desempenho verificado 
seja diferente do desempenho esperado. Conforme o caso, pode-se inclusive optar por redesenho completo, lembrando-se de envolver os profissionais competentes para a discussão (HAMMER, 2002).

Os donos de processo devem ser definidos ao passo que as empresas devem dar a eles poder suficiente e incluí-los desde o início em projetos de melhoria de processos (ŽABJEK et al., 2009). O dono do processo é um indivíduo com autoridade e responsabilidade sobre operação dos processos, no entanto, esta pessoa precisa estar bem ciente do processo e ocupar uma posição relativamente alta na empresa, uma vez que ela representa o processo para toda a empresa (BOYLE, 1995).

Por outro lado, a indeterminação ou ausência de donos de processos são fatores que criam barreiras e conduzem ao fracasso iniciativas de melhoria de processos (AL-MASHARI, M.; ZAIRI, M,1999; GROVER et al., 1995). Ou ainda, em casos de mudanças, os donos de processo são os mais ameaçados, sendo sua experiência de valor inestimável para empresa. Por conseguinte, a incorporação de seu conhecimento à empresa os ajuda a contemplar a mudança de um ponto de vista positivo ao invés de pensarem que seus postos de trabalho estão sendo ameaçados. Para isso, os gerentes têm que motivá-los através de recompensas capazes de influenciá-los a obter sucesso no trabalho (ŽABJEK et al., 2009).

\subsubsection{Participação no Processo}

A carência de visão holística dos processos, aliada a uma preocupação das equipes apenas com as próprias áreas, menosprezando-se clientes internos e externos, são alguns dos fatores que criam conjunto desalinhado de esforços, capazes de fazer equipes de "boas intenções" caminharem em direções diferentes (RUMMLER; BRACHE,1992).

$\mathrm{O}$ encadeamento bem-sucedido de tarefas executadas possibilita às diversas atividades interligadas originar produto final adequado para o cliente. Para tanto, é necessário comprometimento por parte dos envolvidos. Numerosos trabalhos deixam de apresentar resultados adequados pelo fato de os envolvidos não se comprometem com seu desenvolvimento e com sua implementação (OLIVEIRA, 2006)

Lok et al. (2005) enfatiza que apoio da alta gerência é ingrediente essencial para sucesso do processo de mudança. No entanto, mesmo se as empresas criarem ambiente favorável, disponibilidade para mudanças e competência tecnológica necessárias, o esforço de 
melhoria de processos não funcionaria se os empregados vitais não tivessem habilidades elegíveis e o conhecimento sobre o novo processo, ou se eles não forem educados corretamente e em tempo para desempenhar suas funções (GROVER et al., 1995).

A melhoria contínua necessita da participação de todos envolvidos uma vez que deve ser construída e consolidada superando desafios na empresa (SENTANIN et al., 2008). Além disso, o envolvimento dos colaboradores para implementar melhorias também aumenta sua satisfação e retenção na empresa (JULIEN; TJAHJONO, 2009).

Finalmente, para se garantir visão geral da organização e se verificar como atuam as diferentes áreas, é necessário haver, para todos os envolvidos, transparência dos processos e entendimento de sua interação. Os participantes do processo, muitas vezes envolvendo diversas áreas, devem conhecê-lo como um todo, compreendendo como as atividades por eles executadas contribuem para o alcance do objetivo final.

\subsection{Implementação de Melhoria de Processos}

\subsubsection{Contexto Organizacional e Metodologia de Melhoria de Processos}

De acordo com Seethamraju e Marjanovic (2009) melhoria de processos é bem reconhecida como necessidade imperativa para empresas, no entanto, a primeira e mais freqüente pergunta realizada por profissionais ao iniciar tal melhoria de processo é "como"?

Em outras palavras, existe interesse em saber quais metodologias seguir e quais ferramentas utilizar. Segundo Coskin et al. (2008), o sucesso de uma metodologia de melhoria de processos está baseado nas ferramentas e técnicas efetivas que a suportam.

Para lidar com o desafio de desenvolver processos melhores, as empresas cada vez tendem a adotar melhores práticas. Pode-se definir "melhores práticas" como um modo bem sucedido de resolver um problema específico que pode necessitar ser ajustado às condições existentes (MANSAR; REIJERS,2007; SEETHAMRAJU; MARJANOVIC, 2009). Na literatura de melhoria de processos, há exemplos de estudos de definição de melhores práticas e como escolher a mais adequada para fazer melhoria de processos (HANAFIZADEH, 2009; MANSAR; REIJERS, 2007; POVEY,1998). 
Por sua vez, uma metodologia deve fornecer um meio de descrever o conhecimento e a experiência e ainda oferecer determinado nível de estrutura genérica de abordagem destinado a profissionais empregarem em suas situações específicas de negócio (SEETHAMRAJU; MARJANOVIC, 2009).

Metodologias de melhoria fazem tipicamente parte do campo de atuação de empresas de consultoria que desenvolvem métodos próprios para melhoria de processos (KETTINGER et al., 1997). Por outro lado, outras metodologias desenvolvidas por pesquisadores são publicadas em revistas do meio acadêmico. Alguns estudos recentes (COSKUN et al., 2008; BIAZZI, 2007; HANAFIZADEH; MOAYER, 2008; SIHA; SAAD, 2008) apresentam metodologias, próprias ou não, sobre a melhoria de processos.

Muitas questões incluindo o estilo de gestão, cultura organizacional, nível de habilidades dos participantes e as características dos processos - complexidade, escopo, significância, etc. - podem impactar na metodologia de melhoria de processos adotada. Além disso, todas metodologias não são rigorosamente testadas e validadas para diferentes situações de negócio e portanto são limitadas em sua aplicabilidade (SEETHAMRAJU; MARJANOVIC, 2009).

Em análise comparativa de várias de uma série de métodos e ferramentas de melhoria de processos, Povey (1998) afirma que nenhuma das metodologias documentadas na literatura é individualmente capaz de fornecer um procedimento completo para esta finalidade, ou seja, nenhuma delas é robusta suficiente para garantir melhorias sustentadas. A partir deste estudo, Adesola e Baines (2005) por sua vez, afirmam que nenhuma das metodologias de melhoria de processos suportam adequadamente os profissionais de processos durante todas etapas na melhoria de processos.

Do mesmo modo, Vakola e Rezgui (2000) afirmam que muitas abordagens e metodologias não são possíveis de serem praticadas devido aos custos de aplicação associados, ao tempo necessário para sua implementação e a falta de conhecimento sobre seus benefícios potenciais. Para estes autores, verificar a efetividade da aplicação de melhoria de processos é uma questão crítica que não tem sido muito investigada.

Conforme Seethamraju e Marjanovic (2009), dado que cada situação de negócio e cada processo têm características únicas, mostra-se difícil desenvolver e adaptar metodologia universal comum aplicável a todos os tipos de situações e contextos de negócio apresentando bons resultados. Enquanto sempre há oportunidade de aprender a partir de abordagens bem sucedidas existentes e de experiências práticas em situações de estudos de caso, a adaptação e reutilização destas em uma situação diferente não podem garantir qualquer grau de sucesso. 


\subsubsection{Abordagem de Metodologias de Melhoria de Processos}

A maior parte das metodologias para melhoria de processos compartilham fases e características comuns, diferindo no modo de abordagem (DOOMUN, R.; JUNGUM, 2008) e ênfase em uma etapa especifica do processo de melhoria conforme metodologia (SEETHAMRAJU; MARJANOVIC, 2009).

Apesar de diferenças significativas, a maioria das metodologias de melhoria de processos de negócio existentes na literatura consiste tipicamente da maioria das seguintes etapas: desenvolvimento de objetivos; definição de problema e escopo; seleção, mapeamento, análise e modelagem de processos; identificação de fatores de mudança, determinação de áreas problemáticas ou que não proporcionam valor agregado; benchmarking e sugestão de novas soluções; redesenho; implementação, avaliação e melhoria contínua (ADESOLA; BAINES, 2005; BATEMAN, 2005; MCKAY; RADNOR, 1998).

Finalmente, especificamente para propor possíveis soluções a atividades de processos, Mansar e Reijers (2007) apresentam como conclusão de pesquisa uma lista (quadro 1) diretamente aplicável com as dez melhores práticas utilizadas por empresas para obter novos desenhos de processos:

Quadro 1 - As mais populares "melhores práticas" de obter novos desenhos de processos

\begin{tabular}{|c|c|}
\hline Melhores Práticas & Definição \\
\hline Eliminação de tarefa & eliminar tarefas desnecessárias de um processo \\
\hline Composição de tarefa & $\begin{array}{l}\text { combinar pequenas tarefas para compor tarefas agrupadas e dividir tarefas } \\
\text { grandes em tarefas menores }\end{array}$ \\
\hline Integração de tecnologia & $\begin{array}{l}\text { tentar superar restrições físicas em um processo através da aplicação de nova } \\
\text { tecnologia }\end{array}$ \\
\hline Delegação & $\begin{array}{l}\text { reduzir gestão intermediária e dar aos colaboradores grande parte da autoridade } \\
\text { para decidir }\end{array}$ \\
\hline Atribuição de ordem & $\begin{array}{l}\text { fazer colaboradores executarem tarefas únicas em tantas etapas quanto forem } \\
\text { possíveis }\end{array}$ \\
\hline Reordenação & realocar tarefas de forma mais apropriada \\
\hline Especialista-generalista & considerar fazer recursos mais especializados ou mais generalistas \\
\hline Integração & considerar a integração com um processo do cliente ou um fornecedor \\
\hline Paralelismo & considerar se tarefas podem ser executadas em paralelo \\
\hline Envolvimento quantitativo & minimizar o número de áreas, grupos e pessoas envolvidas em um processo \\
\hline
\end{tabular}

Fonte: Adaptado de (MANSAR;REIJERS,2007) 


\subsubsection{Dificuldades de Implementação de Melhoria de Processos}

Enquanto metodologias e ferramentas de melhoria de processos têm ajudado alcançar melhorias significativas em áreas operacionais, muitas empresas têm encontrado dificuldades em implementar e mantê-las no longo prazo (BATEMAN, 2005; PALMBERG,2010). Nesse sentido, Niehaves (2010) afirma que a falta ou escassez de recursos (técnicos, financeiros, de tempo e de pessoas) pode causar um impacto negativo e dificultar a implementação de projetos de melhoria de processos. Baseado na afirmação daquele autor e a partir de estudo da literatura, podemos resumir as seguintes principais dificuldades para implementação de melhoria de processos:

Quadro 2 - Dificuldades para implementação de melhorias

\begin{tabular}{|c|c|c|}
\hline Dificuldades & Definição & Fonte \\
\hline Humanas & $\begin{array}{l}\text { - } \text { resistência das pessoas; } \\
\text { - equipes ineficazes da área de processos nas empresas; } \\
\text { - relutância de colaboradores em cessar ou reduzir } \\
\text { algumas de suas responsabilidades de decisão; } \\
\text { - medo de perder emprego e autoridade sobre os } \\
\text { empregados; } \\
\text { - resistência dos usuários para modificações devido a } \\
\text { descrença sobre os resultados do projeto }\end{array}$ & $\begin{array}{l}\text { Ahmad et al. (2007), Stoddard et } \\
\text { al. (1996); Peppard e Fitzgerald } \\
\text { (1997), Abdolvand et al. (2008); } \\
\text { Hesson et al.(2007),Fisher (2005); } \\
\text { Chew et al.(2006) }\end{array}$ \\
\hline $\begin{array}{l}\text { Tempo e } \\
\text { Recursos } \\
\text { Financeiros }\end{array}$ & $\begin{array}{l}\text { - tempo necessário para implementação da } \\
\text { metodologia; } \\
\text { - disponibilidade de recursos financeiros; } \\
\text { - custos de aplicação associados }\end{array}$ & $\begin{array}{l}\text { Ahmad et al. (2007), Abdolvand } \\
\text { et al. (2008); Hesson et al. (2007), } \\
\text { Vakola e Rezgui (2000) }\end{array}$ \\
\hline $\begin{array}{l}\text { Técnica, de } \\
\text { Tecnologia e } \\
\text { Metodologia }\end{array}$ & $\begin{array}{l}\text { - } \text { aspectos técnicos da mudança; } \\
\text { - problemas relacionados a TI; } \\
\text { - dificuldades em modelar aspectos organizacionais } \\
\text { dentro de uma metodologia; } \\
\text { - dificuldades em modelar fatores humanos dentro de } \\
\text { uma metodologia; } \\
\text { - falta de habilidade das empresas para avaliar os efeitos } \\
\text { das melhorias de processos mapeados antes de sua } \\
\text { implementação; } \\
\text { - falta de conhecimento sobre benefícios potenciais da } \\
\text { metodologia; } \\
\text { - processos de definidos de forma inapropriada (muito } \\
\text { ampla ou muito estreita); }\end{array}$ & $\begin{array}{l}\text { Hackman (2007); Ahmad et al. } \\
\text { (2007), Seethamraju e Marjanovic } \\
\text { (2009), Giaglils (2001), Vakola e } \\
\text { Rezgui (2000), Grover et al. } \\
\text { (1995) }\end{array}$ \\
\hline Política e Gestão & $\begin{array}{l}\text { - falta de apoio e comprometimento da alta gestão; } \\
\text { - falta de gestão de projetos; } \\
\text { - falta de gestão na implementação de mudanças; } \\
\text { - falta de habilidade de generalizar questões transversais } \\
\text { a diversas situações de negócio; } \\
\text { - liderança indecisa } \\
\text { - ausência de objetivos mensuráveis; } \\
\text { - problemas de comunicação; } \\
\text { - desconforto com novo ambiente de trabalho; } \\
\text { - redundância de trabalho após a mudança; }\end{array}$ & $\begin{array}{l}\text { Ahmad et al. (2007), Abdolvand } \\
\text { et al. (2008); Hesson et al. (2007), } \\
\text { Neubauer (2009), Seethamraju e } \\
\text { Marjanovic (2009), Stoddard et al. } \\
\text { (1996); Peppard; Fitzgerald } \\
\text { (1997) }\end{array}$ \\
\hline
\end{tabular}

Fonte: Elaborado pelo autor 


\subsubsection{Fatores Críticos de Sucesso de Implementação de Melhorias de Processos}

Para correta implementação de melhoria de processos (AHMAD et al., 2007) é necessário entender a empresa em si, tanto privada ou pública, e seu contexto de atuação, uma vez que os fatores críticos de sucesso podem ser diferentes.

Na implementação de melhorias, a intervenção da gestão é necessária para adequar os recursos do projeto, tomar decisões rápidas e efetivas, resolver conflitos e trazer todos para o mesmo pensamento. Além disso, a alta gestão deve promover a larga aceitação do projeto e construir cooperação entre os diversos grupos da empresa e em alguns casos além de suas fronteiras. Finalmente, a alta gestão precisa monitorar constantemente o progresso do projeto e providenciar direcionamento para os times de implementação (AL-MUDIMIGH, 2007).

Para complementar essa visão, a tabela seguinte resume a partir da literatura os fatores críticos de sucesso para implementação de melhoria de processos: 
Quadro 3 - Fatores críticos de sucesso (FCS) para implementação de melhorias

\begin{tabular}{|c|c|}
\hline FCS & Definição \\
\hline $\begin{array}{l}\text { Apoio da alta } \\
\text { gestão }\end{array}$ & $\begin{array}{l}\text { - envolvimento e comprometimento total, visível e bem } \\
\text { definido da alta administração, sentido por todos; } \\
\text { - valorização do projeto frente à empresa; } \\
\text { - participação nas tomadas de decisões }\end{array}$ \\
\hline $\begin{array}{l}\text { Alinhamento } \\
\text { estratégico }\end{array}$ & $\begin{array}{l}\text { - estabelecimento de planejamento estratégico para projetos de } \\
\text { melhoria de processos } \\
\text { - escolha precisa de processos a serem aperfeiçoados; }\end{array}$ \\
\hline $\begin{array}{l}\text { Avaliação de } \\
\text { desempenho e } \\
\text { efeito de } \\
\text { demonstração }\end{array}$ & $\begin{array}{l}\text { - medir desempenho de processos para investigar as } \\
\text { consequiências de implementação de melhoria na empresa } \\
\text { - aumento de investimento em projetos cujas ações } \\
\text { implementadas mostraram resultados } \\
\text { - necessidade de evidências tangíveis e concretas de melhorias } \\
\text { implementadas }\end{array}$ \\
\hline $\begin{array}{l}\text { Presença de } \\
\text { liderança }\end{array}$ & $\begin{array}{l}\text { - estabelecimento de gestão de projeto para iniciativas de } \\
\text { melhoria de processos; } \\
\text { - liderança igualitária efetiva coordenando a distribuição e } \\
\text { disponibilidade de recursos; } \\
\text { - criação de ambiente de trabalho colaborativo; } \\
\text { - construção de relações melhores com principais interessados } \\
\text { (funcionários, clientes e fornecedores); } \\
\text { - envolver toda empresa buscando participação das partes } \\
\text { envolvidas }\end{array}$ \\
\hline $\begin{array}{l}\text { Uso efetivo de } \\
\text { tecnologia de } \\
\text { informação }\end{array}$ & $\begin{array}{l}\text { - ter capacidade e infra-estrutura de TI; } \\
\text { - utilização de sistemas de informação para obter, comparar e } \\
\text { processar dados }\end{array}$ \\
\hline
\end{tabular}

Comunicação e transferência de

- comunicação para suportar mudanças do processo conhecimento

Rigor na

- ênfase em compartilhamento de conhecimento implementação de melhorias

- monitoramento de etapas de aplicação da metodologia;

- mudança de processos existentes, transformando práticas de negócio e adaptando processo conforme necessidades do negócio;

- ter estrutura para impedir retrocesso a processos antigos

Gestão da mudança em recursos humanos

- treinamento contínuo de equipe para alcançar resultados desejados;

- redefinição de tarefas, eliminação e reconstrução de procedimentos, etc.;

Fonte

Abdolvand et al. (2008), Ahmad et al.(2007), Al-Mudimigh (2007), Bateman(2005), Gupta (2000), Kamhawi(2008), Lasa et al. (2008), Siha e Saad(2008), Sung e Gibson(1998), Terziovski et al. (2003), Wells (2000)

Sung e Gibson (1998),

Terziovski et al. (2003), Wells (2000), Siha e Saad (2008),

Al-Mudimigh (2007), Lok et al. (2005), Yen (2009)

Abdolvand et al. (2008), Ahmad et al. (2007), Gupta (2000), Škrinjar et al. (2008), Smith (2003), Sung e Gibson (1998), Terziovski et al. (2003), Wells (2000)

Abdolvand et al. (2008), AlMudimigh (2007), Lasa et al. (2008), Siha e Saad (2008), Sung e Gibson (1998), Terziovski et al. (2003), Wells (2000)

Siha e Saad (2008), Smith (2003)

Al-Mudimigh (2007), Bateman, (2005), Lasa et al. (2008), Siha e Saad (2008)

Al-Mudimigh (2007), Bateman (2005), Gargeya e Brady (2005), Gupta (2000), Lasa et al. (2008), Sung e Gibson (1998),

- desenvolvimento de novas habilidades necessárias pelos novos Terziovski et al. (2003), Wells processos;

- estabelecimento de sistemas de gestão para cultivar os valores exigidos e atingir objetivos desejados

Seleção criteriosa de

- escolher e motivar os funcionários certos para participarem na implementação do processo;

colaboradores • perfil de pessoas de alto nível de criatividade, educação, habilidade de lidar com riscos e crença em mudança de processos;

- buscar forma adequada de incorporar facilitadores de melhoria de processos

Concorrência de $\bullet$ pressão de mercado competitivo

mercado $\quad$ fatores específicos do setor econômico da empresa

(2000)

Al-Mudimigh (2007), Bateman (2005), Gupta (2000), Kamhawi (2008)

Kamhawi (2008), Sung e Gibson (1998), Terziovski et al. (2003), Wells (2000) 


\subsection{Indicadores de Processo}

Com a pressão de concorrência, a medida de desempenho organizacional tornou-se altamente necessária para a sobrevivência das organizações. A fim de alcançar a excelência do negócio, é necessário, portanto que a empresa desenvolva um sistema de medição de desempenho (ŠKRINJAR et al., 2008). As medições de processos são de grande importância na gestão de processos porque elas ajudam a controlar, estimar e melhorar processos e assim as próprias empresas (GONZÁLEZ et al., 2010).

Desde os anos 90, o tema indicadores vêm sendo discutido entre autores clássicos da literatura. Kaplan e Norton (1997), por exemplo, afirmam que a melhoria de processos deve ser direcionada por indicadores estratégicos. Em suma, aqueles autores propuseram o balanced scorecard para gestão estratégica da empresa abrangendo a medição do desempenho organizacional sobre quatro perspectivas: financeira, cliente, processos internos da empresa e, aprendizado e crescimento. Desta forma a estratégia pode ser traduzida em objetivos e medidas tangíveis que permitem direcionar a empresa a concentrar esforços na melhoria de processos críticos para sucesso estratégico da empresa.

As empresas passam a acreditar que ações corporativas são boas quando mostram resultados e, só assim aumentam as atividades e investimentos neste tipo de projeto (LOK et al., 2005). Portanto, conforme Yen (2009), os gestores precisam de evidências concretas ou tangíveis das implementações de melhorias em processos. Especificamente, eles precisam saber qual é a contribuição do processo e esta deve ser demonstrada por indicadores bem definidos de desempenho de processos. Este autor destaca ainda que ao avaliar a contribuição de qualquer novo processo, um procedimento geral pode incluir duas tarefas críticas:

- decidir o que medir a partir das saídas de um processo;

- uma comparação destas medições entre os velhos processos e os novos

Nesta linha de atuação, Al-Mudimigh (2007) complementa que as empresas devem ser capazes de estabelecer um sistema de medições de desempenho claro e bem definido capaz de avaliar o desenvolvimento e eventuais problemas que ocorram.

No entanto, Yen (2009) mostra que medir um processo pode ser uma proposta muito difícil porque não há uma única abordagem que satisfaz todas as partes interessadas. Sua dificuldade provém de uma variedade de fatores, sendo alguns deles: objetivos, tipo de processos, perspectivas de processos e complexidade do processo. 
Para facilitar a atividade de monitoramento de processos é fundamental que a coleta de dados relevantes de desempenho seja automatizada. A coleta de dados não deve ser uma tarefa manual adicional para os colaboradores uma vez que informação em tempo real dificilmente pode ser registrada (KÜNG; HAGEN, 2007).

Finalmente, segundo Yen (2009), ao desenhar e implementar um novo processo, é importante assegurar-se que os objetivos pré-determinados dos processos serão atingidos. Isto implica que um conjunto razoável das medidas representando os objetivos do processo deve ser identificado e implementado. Para isso, o autor afirma que o ideal seria utilizar um único indicador para cada processo que esteja de acordo com todas as partes interessadas envolvidas.

\subsection{Análise Crítica do Referencial Teórico}

A abordagem de processos faz parte do cotidiano das empresas em busca de eficiência organizacional e melhoria de resultados. A partir da literatura constata-se que o conceito de processos está presente entre as empresas, despertando, portanto interesse em conhecer como empresas de varejo formalmente definem e aplicam na prática este conceito. Nesse sentido, é importante entender quais tipos de processos são trabalhados nestas empresas e qual a visão delas sobre seus processos agregarem valor para o cliente final.

É possível perceber que a orientação para processos proporciona uma série de melhorias na execução dos processos e consequentemente nos resultados de satisfação dos clientes, qualidade, custos e desempenho financeiro da empresa. Por outro lado, fica evidente a importância de haver gerenciamento holístico, ao invés de foco no resultado de departamento específico ou ainda garantir que os processos estejam direta ou indiretamente relacionados aos objetivos da empresa. Frente ao exposto pela literatura, existe curiosidade em verificar como as empresas escolhem processos a serem melhorados conforme objetivos da empresa e como fazem para obter visão generalizada dos mesmos.

A gestão por processos surge como metodologia que viabiliza melhorias em processos, a partir de abordagens estruturadas, permitindo adaptação ágil às mudanças do negócio. Sua finalidade é monitorar, medir, avaliar e melhorar processos conforme as necessidades da empresa. No caso de empresas de varejo, necessita-se entender se elas de fato praticam, conforme a estratégia do negócio, o "planejamento" e a "organização de atividades" de forma 
coordenada para obter sucesso de resultados em projetos para melhoria de processos. Neste aspecto, será interessante constatar a relação da estrutura hierárquica funcional das empresas frente à abordagem de processos.

A partir da literatura, temos em geral, a melhoria de processos com origem em duas gênesis: reengenharia de processos e melhoria contínua. Neste sentido é importante conhecer quais abordagens as empresas de varejo praticam ou praticaram em um passado recente.

Fazendo uso de abordagem estruturada baseada em gestão por processos, a literatura mostra que a empresa pode desenhar, mapear e atribuir responsáveis pelos processos conforme disponibilidade de ferramentas de tecnologia da informação e necessidade de aprofundar detalhamento de atividades. Nesse sentido, o autor propõe verificar como e em que nível de detalhes empresas documentam seus processos, atribuem responsabilidades (dono do processo), entendendo também benefícios e resultados deste mapeamento, o que permitirá assim ter visão generalizada de como elas compreendem e administram processos.

Independente do contexto da empresa, a intervenção da alta gestão e seu papel na tomada de decisões, construção de cooperação entre as áreas e direcionador na implementação de melhorias é fundamental para obter sucesso nos resultados. Por outro lado, a alta gestão não tem disponibilidade plena para conduzir projetos de melhoria de processos, sendo assim, pode ser interessante verificar em estudo como outras áreas são capazes de envolver e garantir comprometimento e participação de todos.

A revisão bibliográfica não teve como objetivo apresentar e discutir as ferramentas da qualidade. Constatou-se, em geral, etapas comuns nas metodologias de melhoria de processos: realização de diagnóstico, modelagem de processos, identificação de pontos de melhoria, implementação de mudanças e avaliação contínua do negócio. No entanto, não há metodologia universal comum aplicável a todos os setores econômicos e que seja capaz de dar suporte a profissionais nas etapas de implementação de melhoria de processos. Apesar das vantagens e desvantagens de cada uma, existe dependência do contexto organizacional e dos tipos de situações de negócio onde são aplicadas. Portanto, verificar essa informação no contexto de mercado de varejo será um incremento que contribuirá para a literatura de processos.

Considerando contexto amplo englobando todos os tipos de melhoria, levantou-se no referencial teórico uma série de fatores internos e externos à empresa necessários para que a melhoria de processos seja implementada de forma eficaz e permaneça trazendo bons resultados mesmo após a finalização do projeto. 
Dentre as dificuldades de implementação de melhoria de processos temos como principais aquelas relacionadas a aspectos: humanos; de tempo e recursos financeiros; técnicos, de tecnologia e metodologia; além de política e gestão.

Além disso, pode-se constatar de forma sucinta como fatores críticos de sucesso: apoio da alta gestão, alinhamento estratégico, avaliação de desempenho e efeito de demonstração, presença de liderança, uso efetivo de tecnologia de informação, comunicação e transferência de conhecimento, rigor na implementação de melhorias, presença de gestão da mudança em recursos humanos, seleção criteriosa de colaboradores e concorrência de mercado.

Após implementar melhorias em processos, evidências de resultados concretos, demonstrada por indicadores bem definidos de desempenho de processos, despertam interesse da empresa para continuar a investir em projetos deste tipo. Por sua vez, a melhoria de processos deve ser direcionada por indicadores estratégicos. Nesse sentido, será interessante examinar como empresas de varejo utilizam indicadores para constatar a melhoria dos processos e se eles estão alinhados com diretrizes estratégicas.

Em suma, a partir da análise da literatura, podem ser levantadas limitações relevantes a respeito da implementação de melhorias de processos:

- a efetividade da aplicação de melhoria de processos através da abordagem de processos é assunto de interesse a ser investigado;

- dado que a abordagem de processos traz melhoria de resultados, autores questionam como exatamente deve ser feita a melhoria de processos, e quais metodologias e ferramentas utilizar;

- muitas empresas têm encontrado dificuldades em sustentar melhorias no longo prazo;

- são necessários estudos acadêmicos que mostrem na prática a melhoria de processos em setores diferentes da indústria, serviços, educação, saúde, finanças e governo;

- existe interesse em entender e verificar na prática fatores chaves de sucessos, motivos de resistência e como superar dificuldades para implementar melhoria de processos;

- dificilmente encontram-se exemplos de aplicação, em empresas de varejo, de modelo de abordagem estruturada por processos na melhoria de processos;

Diante do exposto, ressalta o interesse em entender de forma prática a implementação de melhoria de processos no contexto organizacional de empresas de varejo.

O estudo descritivo em questão deve ressaltar o contexto organizacional vivenciado pelas empresas, assim como as formas encontradas pelos profissionais de processo para superar dificuldades ao implementar esta solução. 


\section{MATERIAIS E MÉTODOS}

\subsection{Método de Pesquisa}

Em vista do referencial teórico exposto, a seguinte questão de pesquisa é estudada neste trabalho: como grandes empresas do setor de varejo brasileiro atuam para implementar melhoria de processos?

Para responder a esta questão, outras perguntas são necessárias para embasar ou ainda complementar este estudo: como estas empresas definem processos, efetuam mapeamento dos mesmos e quais destes são selecionados para serem melhorados? Como estas empresas planejam e organizam atividades para efetuar melhoria de processos? Quais dificuldades e fatores críticos de sucesso para implementação de melhoria de processos? Como as empresas utilizam indicadores para constatar a melhoria dos processos?

O objetivo de pesquisa estabelece a ação (verbo) a ser conduzida e deve, portanto, ser um fator determinante na escolha da abordagem metodológica (MIGUEL, 2007). Para escolha de método de pesquisa, deve-se considerar: (a) tipo de questão de pesquisa proposta, (b) extensão de controle que o pesquisador tem sobre eventos comportamentais atuais e, (c) grau de enfoque em acontecimentos contemporâneos (YIN,2005).

Analisando os objetivos listados em item anterior e a questão de pesquisa em destaque, pretende-se aprofundar a análise do fenômeno de melhoria de processos em empresa de varejo. Trata-se de uma questão de pesquisa do tipo "como", em que o pesquisador não tem controle sobre os eventos comportamentais cujo foco está em acontecimentos contemporâneos. Portanto, será realizado estudo de caso por tratar-se de natureza empírica para investigar determinado fenômeno, geralmente contemporâneo, dentro de um contexto real de vida, quando as fronteiras entre o fenômeno e o contexto em que aquele se insere não são claramente definidas (MIGUEL, 2007).

Considerando o objetivo da pesquisa, optou-se por realizar pesquisa de estudo de casos múltiplos de empresas do mercado de varejo brasileiro que aplicam abordagem de processos para melhoria de seus processos. Desta forma, a finalidade foi alcançar maior grau de generalização dos resultados a despeito da menor profundidade na avaliação de cada um dos casos (YIN, 2005). 
No entanto, a condução de estudo caso traz certos desafios: consome tempo, necessita habilidades por parte dos entrevistadores, requer atenção para generalização de conclusões a partir de um conjunto limitado de casos e para garantir rigor na pesquisa (VOSS et al., 2002). Assim, no item seguinte, descreve-se mais especificamente a amostra estudada.

\subsection{Amostra e Universos Pesquisados}

O autor deste trabalho buscou constatações do fenômeno estudado em três empresas varejistas do Brasil, entre as dez maiores redes em faturamento do último ano, que possuem área dedicada a processos. Estas três empresas representam juntas cerca de $30 \%$ do varejo nacional (SALLOWICZ; ROLLI , 2011). Destaca-se o interesse de utilização destas empresas no estudo de casos por possuírem Núcleo de Processos, constituído por equipe de consultores internos, encarregados sobretudo à utilização de abordagem de processos nas atividades administrativas e operacionais da empresa. Tais profissionais analisam e avaliam processos, elaborando desenhos com foco na melhoria contínua. Conforme ocorrência, este núcleo atua como facilitador entre as áreas envolvidas na implementação de plano de ação e das melhorias apontadas.

Para determinar o quanto longitudinal são os casos (MIGUEL, 2010), levou-se em consideração que os resultados de melhoria de processos não necessariamente ocorrem de imediato, necessitando de tempo e maturidade para serem avaliados. Diante disso, foi feita escolha também por projetos dentro destas empresas que representassem a implantação de melhoria recente - a partir dos últimos três anos -, relativamente consolidada e realizada em processos de complexidade moderada. Neste contexto, para que a análise pudesse ser mais produtiva do ponto de vista acadêmico, optou-se como critério de escolha projetos de melhoria de processos consistentes em relação aos objetivos gerais da empresa, quantidade e importância das áreas envolvidas, dependendo ainda do nível de abrangência, de restrições de custo e prazo para o pesquisador e é claro da disponibilidade de informações. Os projetos de melhoria de processos escolhidos tratam principalmente de processos de trabalho e ainda se mostram úteis porque afetam indiretamente o cliente final.

Os casos escolhidos estão sintetizados na tabela seguinte: 
Quadro 4 - Casos estudados na pesquisa

\begin{tabular}{|c|c|c|}
\hline Caso & Descrição & Projetos de Melhoria de Processos \\
\hline $\mathrm{A}$ & $\begin{array}{l}\text { Empresa nacional, uma das líderes } \\
\text { do setor de varejo brasileiro de } \\
\text { supermercados. } \\
\text { Núcleo de Processos atua em } \\
\text { mapeamento e melhoria contínua } \\
\text { de processos, desenvolve plano de } \\
\text { ação e promove interação entre as } \\
\text { parte interessadas para implantar } \\
\text { sugestões de melhoria. }\end{array}$ & $\begin{array}{l}\text { Fechamento Definitivo de Lojas: processos abrangendo desde } \\
\text { a tomada de decisão para encerramento definitivo das } \\
\text { operações de venda, passando-se pela desmobilização de } \\
\text { equipamentos, finalização de atividades de apoio prestadas } \\
\text { pelas áreas corporativas da empresa (material de marketing, } \\
\text { pagamento de impostos, baixa de documentação junto aos } \\
\text { órgãos públicos etc.) até a reforma e entrega do imóvel ao } \\
\text { proprietário (em caso de locação). }\end{array}$ \\
\hline $\mathrm{B}$ & $\begin{array}{l}\text { Empresa brasileira, uma das líderes } \\
\text { do setor de varejo não-alimentício } \\
\text { brasileiro, é uma organização de } \\
\text { estrutura familiar. } \\
\text { Area de Qualidade e Processos atua } \\
\text { na melhoria de processos, gestão de } \\
\text { projetos e análise de riscos e de } \\
\text { fraudes. }\end{array}$ & $\begin{array}{l}\text { Distribuição de Uniformes: processos de distribuição de } \\
\text { uniformes de uso obrigatório e facultativo para lojas, centrais } \\
\text { de distribuição e setores administrativo da sede, desde pedido } \\
\text { realizado via sistema até entrega ao colaborador e retirada de } \\
\text { material sem condições de uso. } \\
\text { Gestão de Viagens Corporativas: processos de gestão de } \\
\text { viagens corporativas desde a solicitação até a compra de } \\
\text { passagens, reserva de hotéis, locação de veículos e demais } \\
\text { trâmites junto a agência de viagens prestadora de serviços. }\end{array}$ \\
\hline $\mathrm{C}$ & $\begin{array}{l}\text { Empresa multinacional atuando no } \\
\text { Brasil como uma das líderes de } \\
\text { varejo de supermercados. } \\
\text { Área de Processos responsável pela } \\
\text { documentação, mapeamento e } \\
\text { implantação de melhorias de } \\
\text { processos de todas as áreas } \\
\text { operacionais (lojas) e matriz. }\end{array}$ & $\begin{array}{l}\text { Arquivo Morto: O processo de arquivo morto compreende } \\
\text { todas as etapas desde a separação e organização de } \\
\text { documentos fiscais (notas, bobinas, livros, etc.) feita pelos } \\
\text { colaboradores do setor administrativo das lojas, passando pelo } \\
\text { acondicionamento em caixas, identificação com etiquetas e } \\
\text { envio dos mesmos para prestadora de serviço, até a coleta, } \\
\text { conferência, armazenagem, atendimento a solicitações de } \\
\text { reenvio de documentos em caso de eventuais visitas de } \\
\text { fiscais. } \\
\text { Inventário em Loja: O processo de inventário em lojas } \\
\text { compreende a definição de cronograma e preparação de loja, } \\
\text { passando pela inspeção de loja e contagem de produtos, até a } \\
\text { elaboração de relatório e ajustes de estoque. }\end{array}$ \\
\hline
\end{tabular}

Fonte: Elaborado pelo autor 


\subsection{Planejamento e Operacionalização de Pesquisa}

O autor deste trabalho realizou planejamento e operacionalização da pesquisa, definindo-se também métodos e técnicas para coleta e análise de dados. Desta forma a pesquisa teve as seguintes etapas:

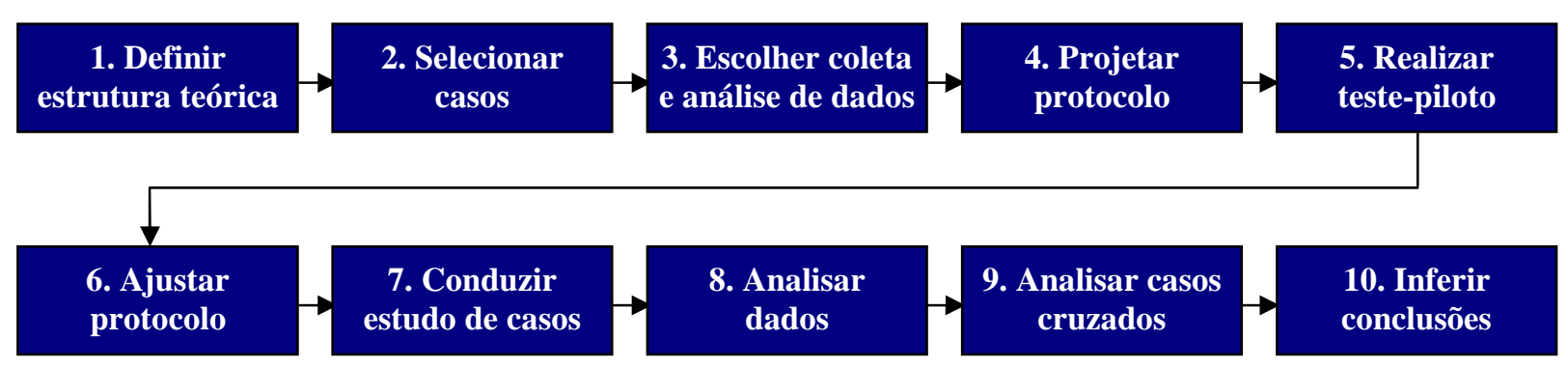

Figura 2 - Operacionalização da pesquisa: condução de estudo de casos

(Fonte: elaborado pelo autor)

1. Definir estrutura teórica: utilização palavras-chave de busca - principalmente process management, process improvement, retail, business process, e business process management - nas bases de dados dos periódicos disponíveis em "ISI Web of Knowledge", "Portal Periódico CAPES", "Scopus" e "USP SibiNet".

Para seleção e descarte de referências utilizaram-se como critérios: coerência, relevância e pertinência ao tema estudado, fator de impacto dos periódicos, indicações de orientador e professores de pós-graduação e preferência para artigos recentes (últimos cinco anos).

A partir do estudo da literatura, foram levantados conceitos associados a gestão por processos utilizados para melhoria de processos, averiguando características de implementação e levantando possíveis lacunas de pesquisa para sua aplicação ao mercado de varejo brasileiro.

2. Selecionar casos: conforme critérios citados em item anterior, foram contatados, através de correio eletrônico e telefone, interlocutores de empresas de varejo com sede no estado de São Paulo, para definir as unidades de análise, empresas a serem estudadas e agendamento de entrevistas. 
3. Escolher coleta e análise de dados: seleção e definição de meios para realizar coleta e análise de dados buscando aumentar confiabilidade e validade da pesquisa.

4. Projetar protocolo: escolhidas as técnicas para coleta e análise de dados, foi elaborado protocolo de pesquisa, incluindo procedimentos para condução do caso, unidades de análise, forma de coleta de dados e fontes de evidência definidos além de esboço de roteiro de entrevista e questionário de pesquisa. Estabeleceu-se também ações a serem tomadas durante a pesquisa com estimativa de prazo de realização.

5. Realizar teste-piloto: apresentação de protocolo para profissional do setor e validação de protocolo pelo orientador. Em seguida, foi realizado teste-piloto na empresa $\mathrm{C}$ pois era aquela que tinha disponibilidade imediata.

6. Ajustar protocolo: a partir da realização do teste-piloto foi possível aprimorar o protocolo de pesquisa adequando-o para reuniões seguintes deste e demais casos - inclusive forma de redação de algumas questões - e verificar a qualidade das informações coletadas relacionando-as com o objetivo da pesquisa.

7. Conduzir estudo de casos: foram realizadas coleta e criação de banco de dados de três casos explorando três empresas varejistas brasileiras de grande porte, tanto em quesito da forma em que está estruturada a organização como em exemplos que estas empresas gerenciam e melhoram processos.

8. Analisar dados: elaboração de relatório detalhado para cada caso estudado executando redução de dados coletados para incluir na análise somente itens associados ao objetivo de pesquisa. A partir disso, o autor preparou para cada caso painel de dados em planilha relacionando itens relevantes da literatura com as fontes de evidência, buscando destacar pontos para responder à pergunta de pesquisa e extrair conclusões válidas a partir desses casos.

9. Analisar casos cruzados: a partir dos diferentes painéis, o autor realizou análise cruzada dos casos buscando relacionar variáveis de pesquisa e verificar padrões e interpretações dos casos. O objetivo foi criar um resumo de evidências para embasar as conclusões, considerando análise de convergência e divergência do cruzamento de informações.

10. Inferir conclusões: elaboração de conclusões sólidas, coerentes com análise estruturada de casos estudados e com as evidências apresentadas. Estas 
conclusões foram comparadas com a teoria de forma a apoiar as evidências e enquadrar os resultados na literatura. De acordo com Miguel (2010) pretende-se verificar se a teoria pode explicar o fenômeno estudado (melhoria de processos utilizando abordagem estruturada baseada em gestão por processos) em contexto diferente (mercado de varejo).

\subsection{Coleta e Análise de Dados}

Estudos de caso normalmente combinam métodos de coleta de dados tais como arquivos, entrevistas, questionários e observações. A evidência pode ser qualitativa (ex.: palavras), quantitativa (ex.: números) ou combinada de ambas. (EISENHARDT, 1989).

Para esta pesquisa foram utilizados métodos de natureza qualitativa na coleta e análise de dados. Conforme sugerido por Yin (2005), a coleta de dados foi realizada a partir de múltiplas fontes de evidência: entrevistas semi-estruturadas com gestores e consultores das áreas concernidas, análise de documentos da empresa - relatórios de sistemas, fluxos, detalhamentos funcionais, normas e procedimentos - além de observação direta e participante da evolução do trabalho ao longo do período estudado.

Para aumentar a confiabilidade da pesquisa de estudo de caso, foi utilizado protocolo (YIN, 2005; VOSS et al., 2002) orientador da coleta de dados, com definição dos devidos procedimentos para condução da pesquisa, indicação de origem das fontes de informação, esboço de relatório e questões do estudo de caso.

Portanto, primeiramente foi realizado contato junto a executivos seniores em condições de autorizar a realização da pesquisa nas empresas e indicar interlocutores adequados para condução de entrevistas.

Em seguida, foram realizadas de uma série de entrevistas ao longo de 2010 para cada um dos casos, sendo uma delas necessariamente com gerente da área e outra com analista ou consultor responsável por executar o projeto de melhoria de processos. Fazendo uso de questionário semi-estruturado, estas entrevistas tiveram duração de duas a duas horas e meia cada uma, e eventuais esclarecimentos de dúvidas foram feitos posteriormente através de contato telefônico. 
Quadro 5 - Entrevistas realizadas na pesquisa

\begin{tabular}{|c|c|c|c|}
\hline Empresa & Entrevistados & $\begin{array}{c}\text { Quantidade de } \\
\text { Entrevistas }\end{array}$ & Temas Abordados nas Entrevistas \\
\hline $\mathrm{A}$ & Gestor de Processos & 02 & $\begin{array}{l}\text { - Responsável pela área de Processos; } \\
\text { - Principal ponto de contato na empresa } \\
\text { - Visão aprofundada do questionário de pesquisa } \\
\text { - Visão geral sobre a empresa e projetos de melhoria } \\
\text { - Entrevistas pessoalmente com duração total de } 4 \mathrm{~h} ;\end{array}$ \\
\hline & Consultor & 02 & $\begin{array}{l}\text { - Responsável por conduzir projeto de melhoria de } \\
\text { fechamento definitivo de lojas sob tutela do Gestor } \\
\text { de Processos; } \\
\text { - Entrevistas pessoalmente com duração total de } 3 \mathrm{~h}\end{array}$ \\
\hline $\mathrm{B}$ & Gerente Sênior & 02 & $\begin{array}{l}\text { - Responsável pela área de Qualidade e Processos; } \\
\text { - Principal ponto de contato na empresa } \\
\text { - Visão aprofundada do questionário de pesquisa } \\
\text { - Visão geral sobre a empresa e projetos de melhoria } \\
\text { - Entrevistas pessoalmente com duração total de } 3 \mathrm{~h} \text {; }\end{array}$ \\
\hline & $\begin{array}{l}\text { Analista de } \\
\text { Processos Pleno }\end{array}$ & 01 & $\begin{array}{l}\text { - Responsável por conduzir projeto de melhoria de } \\
\text { gestão de viagens corporativas sob tutela do Gerente } \\
\text { Sênior; } \\
\text { - Entrevista pessoalmente com duração de } 2 \mathrm{~h}\end{array}$ \\
\hline & $\begin{array}{l}\text { Assistente } \\
\text { Administrativo }\end{array}$ & 01 & $\begin{array}{l}\text { - Responsável por conduzir projeto de melhoria de } \\
\text { distribuição de uniformes sob tutela do Gerente } \\
\text { Sênior; } \\
\text { - Entrevista pessoalmente com duração de } 1 \mathrm{~h}\end{array}$ \\
\hline $\mathrm{C}$ & Gerente Sênior & 02 & $\begin{array}{l}\text { - Responsável pela área de Processos; } \\
\text { - Principal ponto de contato na empresa } \\
\text { - Visão aprofundada do questionário de pesquisa } \\
\text { - Visão geral sobre a empresa e projetos de melhoria } \\
\text { - Visão detalhada sobre o projeto de melhoria de } \\
\text { inventário em loja } \\
\text { - Entrevistas pessoalmente com duração total de } 4 \mathrm{~h} \text {; }\end{array}$ \\
\hline & Especialista & 01 & $\begin{array}{l}\text { - Responsável por conduzir projeto de melhoria do } \\
\text { processo de arquivo morto sob tutela do Gerente } \\
\text { Sênior; } \\
\text { - Entrevista pessoalmente com duração de } 2 \mathrm{~h}\end{array}$ \\
\hline
\end{tabular}

Fonte: Elaborado pelo autor

As entrevistas foram conduzidas fazendo uso de gravador, com autorização dos interlocutores, mantendo ambiente descontraído, agradável e sem inibir respostas ao mesmo tempo em que havia comprometimento e objetividade dos entrevistados. De acordo com Miguel (2010), registros em gravador trazem uma série de vantagens no sentido da melhoria da precisão na análise posterior. 
Logo após as entrevistas ou no dia seguinte, as gravações foram transcritas para relatório de pesquisa e o documento foi enviado via correio eletrônico para revisão e validação dos entrevistados, garantindo validade das informações registradas para a pesquisa. Além disso, durante as entrevistas, a partir de outras fontes de evidência acima citadas, foi realizado registro em papel das principais observações das visitas às empresas para posteriormente serem colocadas em arquivo eletrônico.

Desta forma foi criado banco de dados para cada estudo de caso contendo registro das anotações das entrevistas em relatório de pesquisa juntamente com processos mapeados e documentos explicativos coletados. Isto permitiu manter o encadeamento de evidências, ou seja, houve preocupação com preenchimento dos documentos e coerência das conclusões de entrevistas. O objetivo foi coletar dados de forma a garantir a confiabilidade do caso, e a aumentar a validade do conteúdo, triangulando dados e métodos (MIGUEL,2007; VOSS et al., 2002).

Uma vez que os relatórios de pesquisa estavam validados pelos interlocutores, o autor releu cada um destes documentos para fazer a análise dos casos estudados. Desta maneira, foi realizada codificação de cada caso associando evidências com itens relevantes ligados à questão de pesquisa e à literatura. Em seguida, foi realizada redução dos dados para elaborar relatório detalhado para cada caso estudado incluindo na análise somente itens associados ao objetivo de pesquisa.

A partir disso, o autor preparou painel demonstrativo de dados em planilha MS Excel para cada estudo de caso. O objetivo foi relacionar itens relevantes da literatura com as fontes de evidência, buscando destacar pontos para responder à pergunta de pesquisa e extrair conclusões válidas a partir desses casos.

Tratando-se de estudo de casos múltiplos, para próxima fase da pesquisa, será feita análise cruzada de informações. A finalidade é identificar padrões nos dados e obter convergência e divergência entre as fontes de evidências para embasar as conclusões gerais do estudo de casos. 


\section{ESTUDO DE CASOS}

\subsection{Empresa A}

\subsubsection{Estrutura e Funcionamento}

A empresa A é de origem nacional e uma das líderes do setor de varejo brasileiro de supermercados. Esta empresa possui desde 2007 Núcleo de Processos diretamente atrelado à vice-presidência financeira, atuando em mapeamento e melhoria contínua de processos. Além disso, desenvolve plano de ação e promove interação entre as partes interessadas para coletar e priorizar sugestões de melhoria. Por sua vez, a implementação das ações de melhoria de processos podem ser lideradas pelo Núcleo de Processos, mas na maior parte das vezes é conduzida pela própria área responsável pelo processo ou ainda pelo Escritório de Projetos da empresa.

Quanto à formalização de desenhos de processos, utiliza-se a ferramenta ARIS (Architecture of Integrated Information Systems) para mapeamento de fluxos e registro de detalhamento funcional, sistemas e documentos utilizados nos processos. Quanto à metodologia de desenho utilizada, emprega-se a Cadeia de Processos Dirigida por Eventos (Event-Driven Process Chain - EPC) amplamente utilizada como padrão para modelagem de processos.

\subsubsection{Metodologia para Melhoria de Processos}

A empresa A atua na melhoria contínua de seus processos, não tendo vivenciado em passado recente melhoria de ruptura, somente reestruturações de áreas corporativas baseada em redução de despesas. Da mesma forma, a empresa A não vivenciou iniciativas estruturadas do tipo Lean Production, Kaizen ou Six Sigma. 
Considerando-se as particularidades existentes no varejo, o Núcleo de Processos da empresa A utiliza metodologia própria para melhoria de processos, baseada na cultura organizacional, no benchmarking de serviços prestados por consultorias externas e experiência da equipe, e em conceitos da literatura clássica adaptados à realidade da empresa. Pode-se resumí-la nas seguintes etapas:

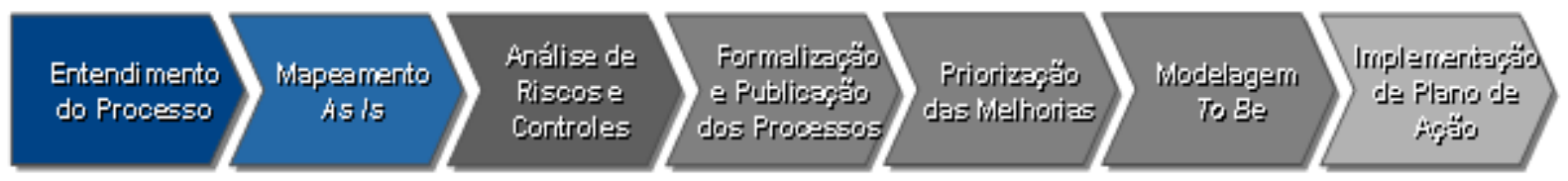

Figura 3 - As etapas para melhoria de processos na empresa A

(Fonte : elaborado pelo autor)

\subsubsection{Atuação para Abordagem de Processos}

A empresa A procura definir claramente as diferentes componentes do estudo de processos. Podem-se verificar níveis de diferenciação de acordo com a figura seguinte:

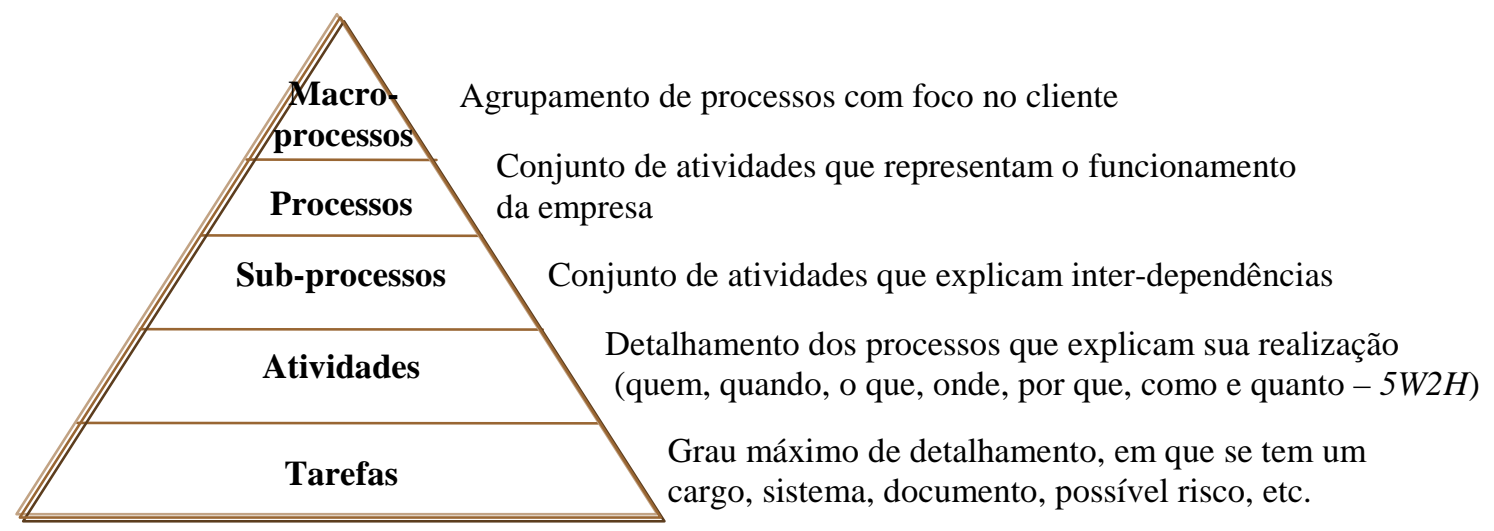

Figura 4 - Os níveis que compõem o estudo de processos na empresa A

(Fonte : documentos da empresa A)

A análise e o mapeamento de processos são vistos pela empresa A como suporte para as atividades desempenhadas pelas áreas corporativas Desta forma, o Núcleo de Processos realiza o mapeamento de processos nos diferentes níveis de detalhamento conforme o objetivo da demanda trabalhada, a qual nominamos neste trabalho projeto de melhoria de processos. 
Todo processo mapeado, por sua vez, é descrito conforme a seguinte estrutura: "Este processo descreve [o que] desde [atividade inicial] até [atividade final] com a finalidade de [para quê]." onde [o que] representa uma breve descrição do processo, [atividade inicial] e [atividade final] representam respectivamente primeira e última atividade do processo, e finalmente [para quê] traz o objetivo do processo, estando implícito em que ele agrega valor para o macro-processo do qual faz parte.

A presença do Núcleo de Processos, formado por consultores especializados na condução de projetos de melhoria de processos, busca difundir a importância de se enxergar o processo como um todo a cada contato com as áreas corporativas. No entanto, as áreas corporativas atuam ainda de forma departamental, ou seja, cada área preocupa-se em executar suas atividades sem necessariamente conhecer a visão do todo no processo em que participa.

A dedicada equipe do Núcleo de Processos busca a visão holística dos processos, destacando os principais pontos de melhoria. Para isso, está focada em cumprir determinadas tarefas durante a fase de mapeamento:

- registro do fluxo do processo: a partir de entrevistas com os executores das atividades, a equipe registra o fluxo do processo, construindo-se seu desenho de forma a ordenadamente encadear as atividades, formalizando-se atribuições e responsabilidades das áreas envolvidas;

- enquadramento do processo: os desenhos definem rigorosamente as atividades de início e fim do processo. Para cada uma das atividades, definem-se claramente entradas, executores, documentos, sistemas, periodicidade e saídas, procurando questionar o executor da atividade com a técnica $5 \mathrm{~W} 2 \mathrm{H}$ (who, when, what, where, why, how e how much, respectivamente quem, quando, o que, onde, por que, como e quanto);

- elaboração de detalhamento funcional: todas as atividades são descritas em documento à parte, identificando-se contexto, sistemas, documentos, periodicidade e condições para execução da atividade. Além disso, são explicitadas deficiências e oportunidades, definindo-se claramente os pontos a serem posteriormente trabalhados;

- apontamento de deficiências e oportunidades: ao longo das entrevistas, registram-se nos desenhos dos processos as principais deficiências e oportunidades de melhorias coletadas com os próprios executores ou sugeridas pelo consultor de processos; 
- validação de fluxo do processo: um único sub-processo pode envolver diversas áreas; no entanto, uma vez finalizado o desenho, todos os responsáveis (coordenadores e/ou gerentes) validam o documento final mediante assinatura. São realizadas quantas reuniões forem necessárias para reproduzir fielmente o processo e obter aprovação formal de todos.

$\mathrm{O}$ fato de apresentar metodologia estruturada para mapeamento de processos (envolvendo questionamento $5 \mathrm{~W} 2 \mathrm{H}$, análise de riscos e implantação de controles e validação dos gestores envolvidos no processo) auxilia a evidenciar a visão do todo, entendendo o encadeamento dos sub-processos para atingir o objetivo final. Além disso, existe constante tentativa de imparcialidade dos consultores frente ao viés de cada entrevistado, buscando-se a melhoria contínua do processo como um todo, não apenas focando-se os objetivos da área entrevistada.

As demandas vindas de áreas corporativas e de lojas da empresa são formalizadas, por documento padronizado, com a indicação de sponsor e de responsável, considerado o ponto focal entre o Núcleo de Processos e demandante. Para ser aprovada, a demanda deve ser devidamente justificada por critérios pré-estabelecidos (diminuição de despesas, aumento de lucro, atendimento a regulamentações legais etc.) bem como estar prevista no orçamento anual da área demandante. Isto não significa que a escolha de projetos de melhoria de processos seja reflexo do desdobramento do planejamento estratégico da empresa, no entanto, essa demandas devem ser programadas e orçadas com antecedência.

Esta forte dependência de financiamento de outras áreas traz consequiências, por exemplo, quando se necessita reduzir despesas e, portanto alguns projetos de melhoria de processos são interrompidos, pois não são encarados como prioridade pelas áreas.

Dessa forma, o Núcleo de Processos não necessariamente atua de forma pró-ativa na proposta de quais projetos de melhoria de processos serão trabalhados. Isto acontece devido toda demanda necessitar indicação de sponsor, ou seja, um patrocinador do projeto, visto que implica em despesas para contratação de recursos (consultores e analistas de processos) para executar demanda sob orientação do gestor e de consultores internos do Núcleo de Processos. Portanto, a atuação em demandas depende do interesse das áreas corporativas em melhorar seus processos, mas não necessariamente estes processos estão diretamente ligados ao cliente final. Isto é retratado no exemplo de projeto de melhoria de processo descrito no item a seguir.

A empresa A utiliza diversos tipos de documentos, conforme a necessidade, para formalizar atividades e comunicar aos envolvidos. Dentre eles, temos: 
- norma: descreve as políticas da empresa que são as diretrizes da alta administração, regula procedimentos, atos, princípios, preceitos, regras, leis, disposição legal;

- procedimento: faz parte da norma e detalha o funcionamento do processo e atividades executadas pelas áreas, trata do modo de fazer, técnica, método, maneira de agir, modo de proceder, de portar-se, conduta, comportamento;

- manual: descreve os procedimentos e regulamentos que prestadores de serviços e fornecedores devem seguir;

- oriente-se: conteúdo relacionado a rotinas e procedimentos de trabalho que demandem uma alteração ou ação concreta;

- formulário: fichas, formulários, lista de verificação e demais documentos em branco;

- guia de ferramenta: procedimentos de sistema, acrescentado de procedimentos administrativos que servem de base para o treinamento, capacitação e orientação de usuários;

- documentos gerais: qualquer documento que não se enquadre em nenhuma das classificações anteriores (ex.: organograma, glossário, etc.);

Por sua vez, dentro de uma demanda, para priorizar processos a serem melhorados, o Núcleo de Processos considera, a partir da análise do negócio, as variáveis que impactam o objetivo principal da demanda em questão (vide exemplo no item "5.1.4” a seguir). Além disso, ocorre também discussão da viabilidade de implantação das melhorias com os colaboradores envolvidos no processo, ponderando-se também neste momento a capacidade e prazo da área de TI atender novas demandas.

Os resultados a serem obtidos após implementação de melhorias são apresentados aos envolvidos em diversas reuniões, mas não necessariamente são demonstradas através de resultados concretamente atingidos. Cabe ao Núcleo de Processos juntamente com a área patrocinadora do projeto de melhoria de processo evidenciar os benefícios das mudanças.

Para isso, a atribuição de um "dono" do processo, estabelecido na formalização da demanda, junto ao apoio de um sponsor da alta diretoria, incentiva a participação e a disponibilidade dos gestores, além de possibilitar o comprometimento para aceitação de mudança de processos.

Outro ponto relevante é a preocupação constante com a elaboração de documentação de qualidade considerável e padronizada, validada por todos os envolvidos, destacando-se o detalhamento funcional dos fluxos e a presença de sistemas e documentos utilizados. Apesar dos sub-processos serem validados por coordenadores ou gerentes das áreas envolvidas, não 
há atribuição de um "dono" para cada um deles, mas cada executor conhece as responsabilidades e resultados de suas atividades.

Com a formalização dos desenhos, os executores das tarefas se percebem inseridos no processo como um todo, compreendendo melhor a importância do comprometimento com o resultado esperado. Isto passa a ter maior evidência quando ocorre a publicação dos processos no portal interno da empresa, garantindo-se a visibilidade holística do processo a partir de sua formalização em documento-padrão.

Desta forma, de um lado busca-se a participação constante dos interlocutores que, por sua vez, apresentam interesse em agilizar a melhoria dos processos, deixando-se em segundo plano interesses específicos para focar na otimização do processo. Por outro lado, às vezes, pode haver dificuldades de gestão na implementação de melhorias devido à problemas (comunicação, mudança de interlocutores, etc.) na transição de líder de projeto do Núcleo de Processos para área demandante ou Escritório de Projetos. Dessa forma, o plano de ação demora a ser colocado em prática e, portanto as áreas deixam de enxergar os resultados do projeto de melhoria optando por executar somente as atividades operacionais do dia a dia.

Além disso, dado o nível inicial de maturidade de conceitos e cultura de processos, a empresa A ainda não trabalha com identificação e definição de indicadores de desempenho de processo, devidamente consistentes com a missão estabelecida para o mesmo. Algumas vezes ocorre apenas a análise histórica de dados que possam refletir a(s) melhoria(s) implantadas. Nesse sentido, não há indicadores claros e consistentes ligando os processos mapeados a objetivos concretos ou estratégicos da empresa.

\subsubsection{Exemplo de Projeto de Melhoria de Processos}

A partir da pesquisa de campo, o autor pode coletar informações a respeito de um projeto (quadro 6) de melhoria de processos na empresa A: fechamento definitivo de lojas (quadro 7). 
Quadro 6 - Exemplo de projeto de melhoria de processos na empresa A

\begin{tabular}{|c|c|c|}
\hline $\begin{array}{c}\text { Projeto de } \\
\text { Melhoria }\end{array}$ & Definição $^{1}$ & Histórico \\
\hline $\begin{array}{c}\text { Fechamento } \\
\text { Definitivo de } \\
\text { Lojas }\end{array}$ & $\begin{array}{l}\text { Processos abrangendo desde a tomada de } \\
\text { decisão para encerramento definitivo das } \\
\text { operações de venda, passando-se pela } \\
\text { desmobilização de equipamentos, } \\
\text { finalização de atividades de apoio } \\
\text { prestadas pelas áreas corporativas da } \\
\text { empresa (material de marketing, } \\
\text { pagamento de impostos, baixa de } \\
\text { documentação junto aos órgãos públicos } \\
\text { etc.) até a reforma e entrega do imóvel } \\
\text { ao proprietário (em caso de locação). }\end{array}$ & $\begin{array}{l}\text { A empresa A analisa constantemente os resultados de } \\
\text { suas lojas, tomando decisão de encerrar as atividades } \\
\text { da loja quando esta tem prejuízos constantes e } \\
\text { permanece sem possibilidade de recuperação. Uma } \\
\text { vez tomada decisão por parte da Diretoria de } \\
\text { Operações, as demais áreas atuam dentro de seus } \\
\text { limites executando atividades necessárias para } \\
\text { garantir o fechamento definitivo da loja. } \\
\text { Nesse sentido, a diretoria de Investimentos e Obras, } \\
\text { responsável pelo centro de custo de lojas fechadas, } \\
\text { solicitou ao Núcleo de Processos mapear todos os } \\
\text { processos ligados ao fechamento definitivo de lojas, } \\
\text { com objetivo de diminuir as despesas decorridas } \\
\text { nestas atividades e conseqüentemente, alocadas } \\
\text { naquele centro de custo. }\end{array}$ \\
\hline
\end{tabular}

Fonte: Elaborado pelo autor

\subsubsection{Fechamento Definitivo de Lojas}

Após ser contratada pela diretoria de Investimentos e Obras, responsável pelo centro de custo de lojas fechadas, o Núcleo de Processos atuou nesta demanda durante os anos de 2008 e de 2009 por meio de um Consultor de Processos supervisionado pela gerência. O objetivo da demanda foi realizar entendimento do processo, mapear processos atuais (As Is), realizar análise de riscos e controles, publicar processos no portal da empresa e priorizar melhorias com foco na redução de despesas de atividades de fechamento definitivo de lojas. A fase de sugestão de novo modelo ( $T o B e$ ) e implementação de plano de ação, neste caso, não foram contempladas neste projeto.

\section{- Entendimento do processo}

A partir de entrevistas com o responsável pela demanda e com profissionais da empresa conhecedores do histórico do processo, formalizaram-se os sub-processos e a inter-relação

\footnotetext{
${ }^{1}$ Conforme já mencionado no quadro 4 do item 4.2
} 
entre as áreas atuantes, desde a tomada de decisão de encerramento definitivo de operações até a entrega do imóvel. Em geral, estabeleceram-se duas fases de fechamento definitivo de loja: pré-fechamento (um único processo, composto pela análise de custos e comunicação de fechamento definitivo aos envolvidos) e pós-fechamento (diversos processos executados pelas áreas para operacionalizar o fechamento definitivo da loja).

\section{- Mapeamento As Is - realidade do processo}

Finalizada a etapa de entendimento geral do processo, foram efetuadas reuniões com os executores das atividades para se mapear os sub-processos envolvidos no fechamento definitivo de lojas. Conforme mencionado no item "5.1.3", nesta fase foi possível formalizar o registro do fluxo do processo, definir pontos importantes das atividades, elaborar detalhamento funcional, apontar deficiências e oportunidades e validação o fluxo do processo mediante assinatura de todos envolvidos. Finalmente, o mapeamento foi encaminhado para a análise de riscos e controles de cada uma de suas atividades.

\section{- Análise de riscos e controles}

A empresa possui área de Controles Internos, especialmente dedicada ao levantamento e à análise de riscos dos processos, além de elaboração e implantação de controles com o objetivo de mitigar eventuais perdas financeiras, erros de processo ou fraudes.

As atividades foram analisadas tanto a partir dos fluxos como das informações levantadas durante as entrevistas de mapeamento, devidamente documentadas nos descritivos, com objetivo de tornar evidentes riscos financeiros para a companhia. Em seguida, foram implantados controles para estas atividades de forma a não burocratizar a fluidez do processo, garantindo-se apenas sua adequação às novas especificidades.

\section{- Formalização e publicação de processos}

Finalizada a etapa anterior, os processos foram publicados no portal interno da empresa e a consulta foi disponibilizada a todos os envolvidos, podendo-se, assim, tomar conhecimento da informação como um todo. O objetivo desta etapa é garantir o comprometimento dos envolvidos, de forma que tomem conhecimento do papel desempenhado e das consequiências de suas respectivas atividades no todo do processo. Além disso, procurou-se divulgar a função do "dono" do processo de fechamento definitivo de lojas, no caso, um dos gerentes da diretoria de Investimentos e Obras, cabendo a ele a responsabilidade de monitorar e acompanhar o desempenho dos sub-processos pertinentes. 


\section{- Priorização de melhorias}

A seleção de processos de melhoria prioritária levou em consideração fatores que impactam o objetivo principal do processo de fechamento de lojas: a redução de despesas. Estes fatores foram obtidos a partir da análise dos componentes do demonstrativo de lucros e perdas da empresa. Dentre eles, destacam-se:

$\rightarrow$ quebra: perda de mercadorias por avaria, violação e degustação, vencimento e maturação de produto, defeitos de equipamentos ou problemas do fornecedor;

$\rightarrow$ logística: transporte de mercadorias ou equipamentos entre lojas ou da central de distribuição até a loja em fechamento;

$\rightarrow$ operações comerciais: compra de mercadorias realizadas pelo departamento comercial da empresa;

$\rightarrow$ tecnologia da informação (TI) e serviços de terceiros: serviços prestados pela área de TI da empresa ou por empresas terceirizadas (Ex: limpeza);

$\rightarrow$ publicidade e marketing: todo o material de propaganda e divulgação (tablóides, guerrilhas, folhetos, stoppers, testeiras de gôndola, etc.);

$\rightarrow$ impostos, taxas e seguros: impostos pagos ao governo, taxas e multas assim como seguros de mercadorias, equipamentos, valores, bem como o próprio imóvel;

$\rightarrow$ despesas corporativas: deslocamento de equipe da sede até a loja em fechamento, levantamento de documentos, honorários jurídicos, etc.;

$\rightarrow$ pessoal: questões envolvendo recursos humanos em geral;

$\rightarrow$ serviços públicos: serviços prestados por órgãos que atingem todo o público, sobretudo o fornecimento de água, luz, gás e telecomunicações;

$\rightarrow$ aluguel: questões relacionadas ao aluguel e ao proprietário do imóvel;

$\rightarrow$ operações de loja: operacionalização das atividades em chão de loja, em contato direto ou não com clientes.

Para cada sub-processo levantado, os consultores internos do Núcleo de Processos realizaram avaliação de duas naturezas:

$\rightarrow$ Avaliação de impacto sobre os negócios, por meio da atribuição de pesos a fatores ligados ao negócio e da avaliação da intensidade da correlação (neste caso os itens "Pessoal”, "Serviços Públicos", Aluguel” e “Operações de Loja” tiveram maior ponderação em relação aos demais fatores devido representarem historicamente os maiores gastos percentuais e/ou serem atividades essenciais para funcionamento da loja); 
$\rightarrow$ Avaliação da qualidade de desempenho, em função do atendimento a expectativas e necessidades, baseado na sensibilidade dos consultores e entrevistados frente ao apontamento de deficiências e oportunidades na fase de mapeamento;

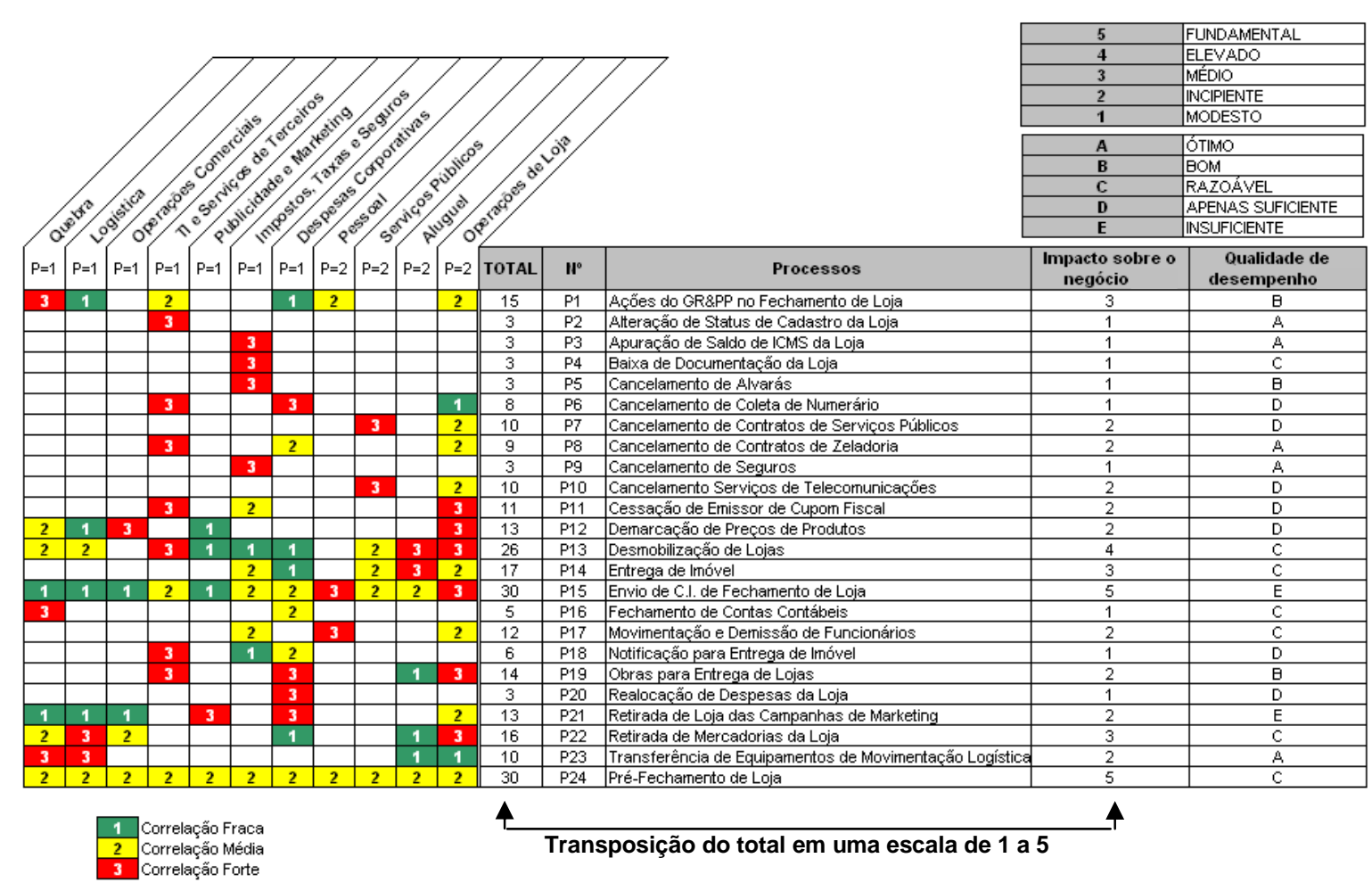

Figura 5 - Fechamento definitivo de lojas: impacto sobre o negócio e qualidade de desempenho

(Fonte : documentos da empresa A)

Na figura 5, em "Notificação para Entrega de Imóvel", por exemplo, fica evidente a forte correlação com "TI e Serviços de Terceiros" dado que as atividades das empresas prestadoras de serviços são diretamente prejudicadas com o fechamento da loja, acarretando "Despesas Corporativas" para notificação (correlação média) influenciando de certa forma o pagamento de multas ("Taxas, Impostos e Seguros") caso a notificação não seja feita em período previsto em contrato.

Finalmente, foi construída matriz com os sub-processos a serem priorizados, segundo os seguintes critérios:

$\rightarrow$ urgência: importância fundamental e desempenho inadequado;

$\rightarrow$ melhorar: importância média e desempenho inadequado;

$\rightarrow$ aprimorar: importância fundamental e desempenho adequado;

$\rightarrow$ adequar: importância discreta e desempenho adequado. 


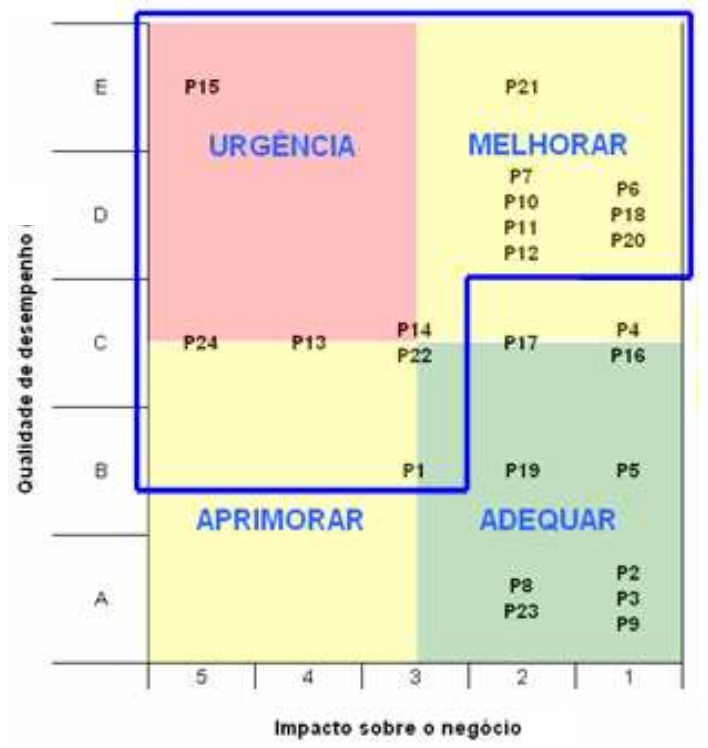

Figura 6 - Fechamento definitivo de lojas: priorização de melhorias

(Fonte : documentos da empresa A)

Até finalização desta fase de "Priorização de Melhorias", foram realizadas discussões sobre o processo de fechamento definitivo de lojas envolvendo mais de cinqüenta interlocutores. Como resultado final, a empresa obteve o mapeamento de um total de vinte e quatro fluxos validados com gestores das áreas, além da criação de detalhamento funcional das atividades. Para cada uma das atividades dos fluxos, conforme o caso, foi realizada análise de oportunidades, gargalos, desperdícios, retrabalhos, fontes de erro, falta de controle, atrasos e deficiências.

Podemos destacar especificamente que a formalização do sub-processo "Pré-fechamento de Lojas" possibilitou envolver indiretamente diversas áreas corporativas no processo de tomada de decisão de fechamento, o que não acontecia anteriormente. As áreas corporativas passaram a fornecer previamente para diretoria de Investimentos e Obras os valores de custos envolvidos para executar fechamento definitivo de uma loja. Estas informações passaram a ser consolidadas em relatório utilizado na tomada de decisão de encerrar atividades daquela loja.

Em geral, a disponibilidade e o comprometimento dos interlocutores se mostraram indispensáveis para a realização do mapeamento dos fluxos. O estabelecimento de um "dono do processo", com envolvimento da alta administração, incentivou a participação dos principais gestores.

Além disso, o fato do Núcleo de Processos da empresa conduzir reuniões, mapear e formalizar sub-processos de fechamento definitivo de lojas, gerou interesse da parte dos 
gestores em discutir o assunto e buscar resolver dificuldades pendentes, esquecidos no dia-adia da organização.

Apesar das fases "Modelagem To Be" e "Implementação de Plano de Ação" não terem sido contempladas neste projeto de melhoria de processos, podemos explicitar a seguir, apenas para conhecimento, as tarefas geralmente executadas nestas fases:

\section{- Modelagem To $\mathrm{Be}$ - delineamento dos processos ideais}

Nesta etapa, ocorrem reuniões com as partes envolvidas, em cada um dos sub-processos, para discutir e validar as oportunidades identificadas. São levadas em consideração viabilidade da mudança, análise de custo e retorno, além de prazo de implementação.

Após validação das oportunidades, criam-se os desenhos do processo ideal e de suas inter-relações, identificando-se papéis e responsabilidades, bem como suas variações por processos. Vale ressaltar que, neste momento, também ocorre, de forma genérica, o mesmo passo-a-passo de formalização dos fluxos da fase de mapeamento As Is.

\section{- Implementação de Plano de Ação}

De acordo com a priorização estabelecida na fase anterior e após modelagem da fase To $B e$, prossegue-se com a implementação do plano de ação. São definidas ações para operacionalizar a implantação do modelo To Be, assim como atividades de melhoria para cada deficiência e oportunidade levantadas, com respectivo responsável e prazo de realização. Conforme citado no item "5.1.1", a implementação do plano de ação, conforme a demanda pode ser liderada pelo Núcleo de Processos, mas na maior parte das vezes é conduzida pela própria área responsável pelo processo ou ainda pelo Escritório de Projetos da empresa. 
Quadro 7 - Exemplo de melhoria do processo de fechamento definitivo de lojas

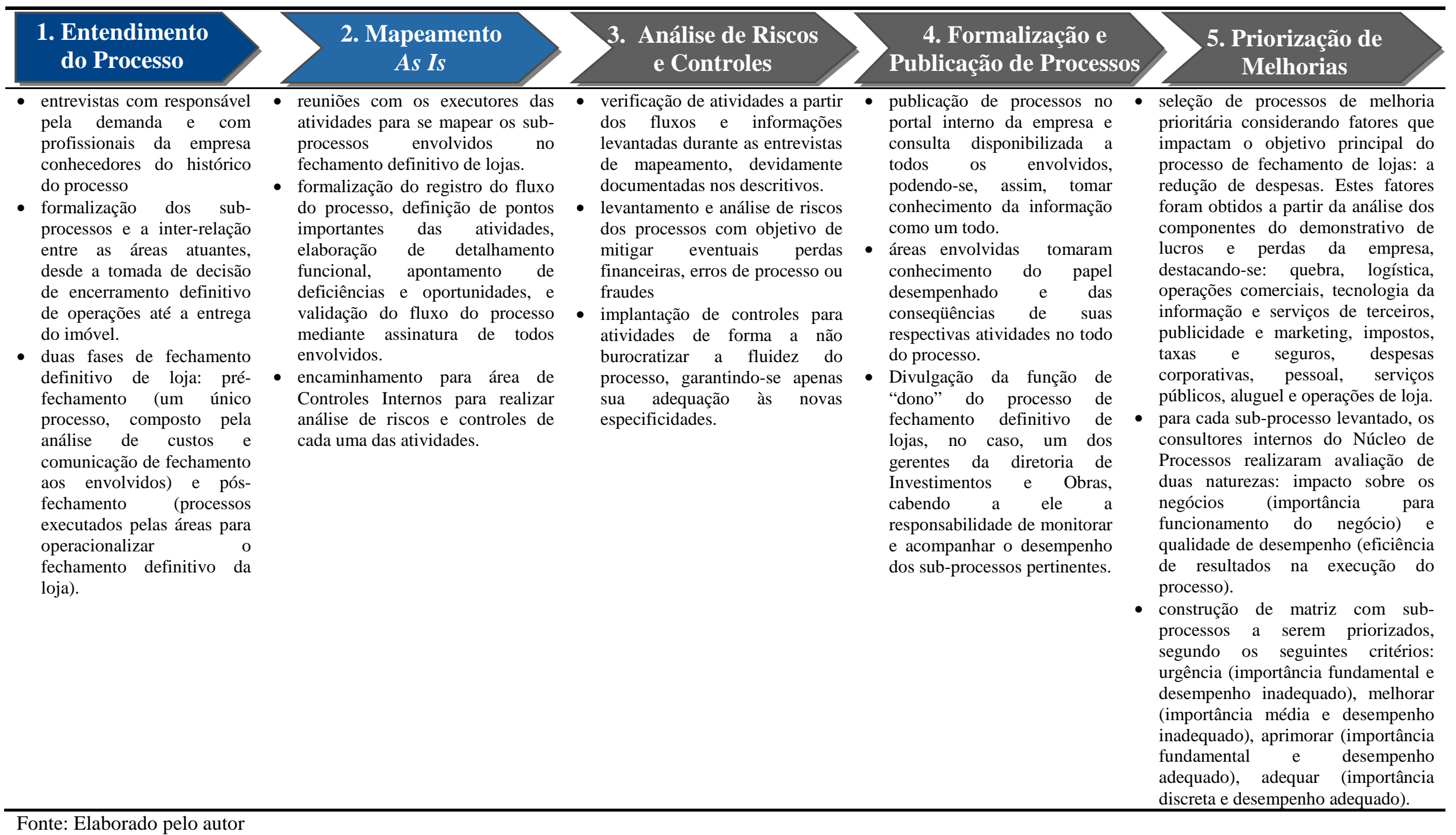




\subsubsection{Análise do Caso A}

A partir das informações coletadas na pesquisa de campo, o autor pode preparar para o caso A painel de dados (quadro 8) relacionando itens relevantes da literatura com as fontes de evidência, buscando destacar pontos para responder à pergunta de pesquisa.

Quadro 8 - Conceitos da literatura e análise do caso A

\begin{tabular}{|c|c|}
\hline $\begin{array}{c}\text { Conceitos da } \\
\text { Literatura }\end{array}$ & Análise do Caso A \\
\hline (3.1) Processos & $\begin{array}{l}\text { - possui definição formal de processos como conjunto de atividades que representam o } \\
\text { - nuncionamento da empresa; } \\
\text { - tóvel inicial de maturidade de conceitos e cultura de processos; } \\
\text { para macro-processo do qual faz parte, não necessariamente para o cliente final; } \\
\text { - projetos de melhoria de processos escolhidos conforme foco da área patrocinadora, não } \\
\text { sendo necessariamente desdobramento do planejamento estratégico da empresa; } \\
\text { - divulgação de processos somente via intranet da empresa; }\end{array}$ \\
\hline $\begin{array}{l}\text { (3.2) Gestão por } \\
\text { processos }\end{array}$ & $\begin{array}{l}\text { - atuação do Núcleo de Processos de forma coordenada, seguindo metodologia própria e } \\
\text { estruturada para melhoria de processos; } \\
\text { - áreas corporativas atuam de forma departamental, ou seja, executam atividades sem } \\
\text { necessariamente conhecer a visão do todo do processo; } \\
\text { - após participação em projetos de melhoria de processos, as áreas corporativas tomam } \\
\text { conhecimento do papel desempenhado e das consequiências de suas respectivas } \\
\text { atividades no todo do processo; }\end{array}$ \\
\hline $\begin{array}{l}\text { (3.3) Melhoria de } \\
\text { processos }\end{array}$ & $\begin{array}{l}\text { - atuação em melhoria contínua de processos, sem ter vivenciado iniciativas estruturadas } \\
\text { do tipo Lean Production, Kaizen, Six Sigma, mas empresa já passou por reestruturação } \\
\text { para redução de despesas; } \\
\text { - registro do fluxo do processo, com elaboração de detalhamento funcional de atividades } \\
\text { - segundo metodologia } 5 W 2 H \text {, apontando deficiências e oportunidades; } \\
\text { - validação de processos, através de assinatura de todos participantes, nos desenhos As Is } \\
\text { e To Be; } \\
\text { - atribuição de "dono" do processo, estabelecido na formalização da demanda, junto ao } \\
\text { apoio de um sponsor da alta diretoria; no entanto não há atribuição de "dono" para cada } \\
\text { - mub-processo do projeto de melhoria de processos; } \\
\text { - tododo, entendendo o encadeamento dos processos para atingir o objetivo final; } \\
\text { - priorização de processos a serem melhorados, a partir da análise de variáveis que } \\
\text { impactam o objetivo principal da demanda em questão; } \\
\text { - discussão da viabilidade de implantação das melhorias com envolvidos no processo. }\end{array}$ \\
\hline $\begin{array}{l}\text { (3.4) Implementação } \\
\text { de melhoria de } \\
\text { processos }\end{array}$ & $\begin{array}{l}\text { - metodologia própria para melhoria de processos, baseada na cultura organizacional, no } \\
\text { benchmarking de serviços prestados por consultorias externas e experiência da equipe, e } \\
\text { em conceitos da literatura clássica adaptados à realidade da empresa; } \\
\text { - fases: entendimento do processo, mapeamento As Is, análise de riscos e controles, } \\
\text { formalização e publicação dos processos, priorização das melhorias, modelagem To Be, } \\
\text { implementação de plano de ação. }\end{array}$ \\
\hline
\end{tabular}




\begin{tabular}{|c|c|}
\hline $\begin{array}{c}\text { Conceitos da } \\
\text { Literatura }\end{array}$ & Análise do Caso $A$ \\
\hline$\checkmark \quad$ Dificuldades & $\begin{array}{l}\text { - } \text { humanas: áreas podem deixar de enxergar os resultados do projeto de melhoria optando } \\
\text { por executar somente as atividades operacionais do dia a dia; } \\
\text { - de tempo e recursos financeiros: quando se necessita reduzir despesas, dependência de } \\
\text { financiamento de outras áreas pode interromper projetos de melhoria de processos pois } \\
\text { estes não são encarados como prioridade; } \\
\text { - técnica, de tecnologia e metodologia: capacidade e prazo da área de TI para atender } \\
\text { novas demandas pode limitar implementação de ações de melhoria; } \\
\text { - política e gestão: dificuldades de gestão na implementação de melhorias devido à } \\
\text { problemas (comunicação, mudança de interlocutores, etc.) na transição do projeto do } \\
\text { Núcleo de Processos para área demandante ou Escritório de Projetos; }\end{array}$ \\
\hline $\begin{array}{l}\checkmark \text { Fatores críticos } \\
\text { de sucesso }\end{array}$ & 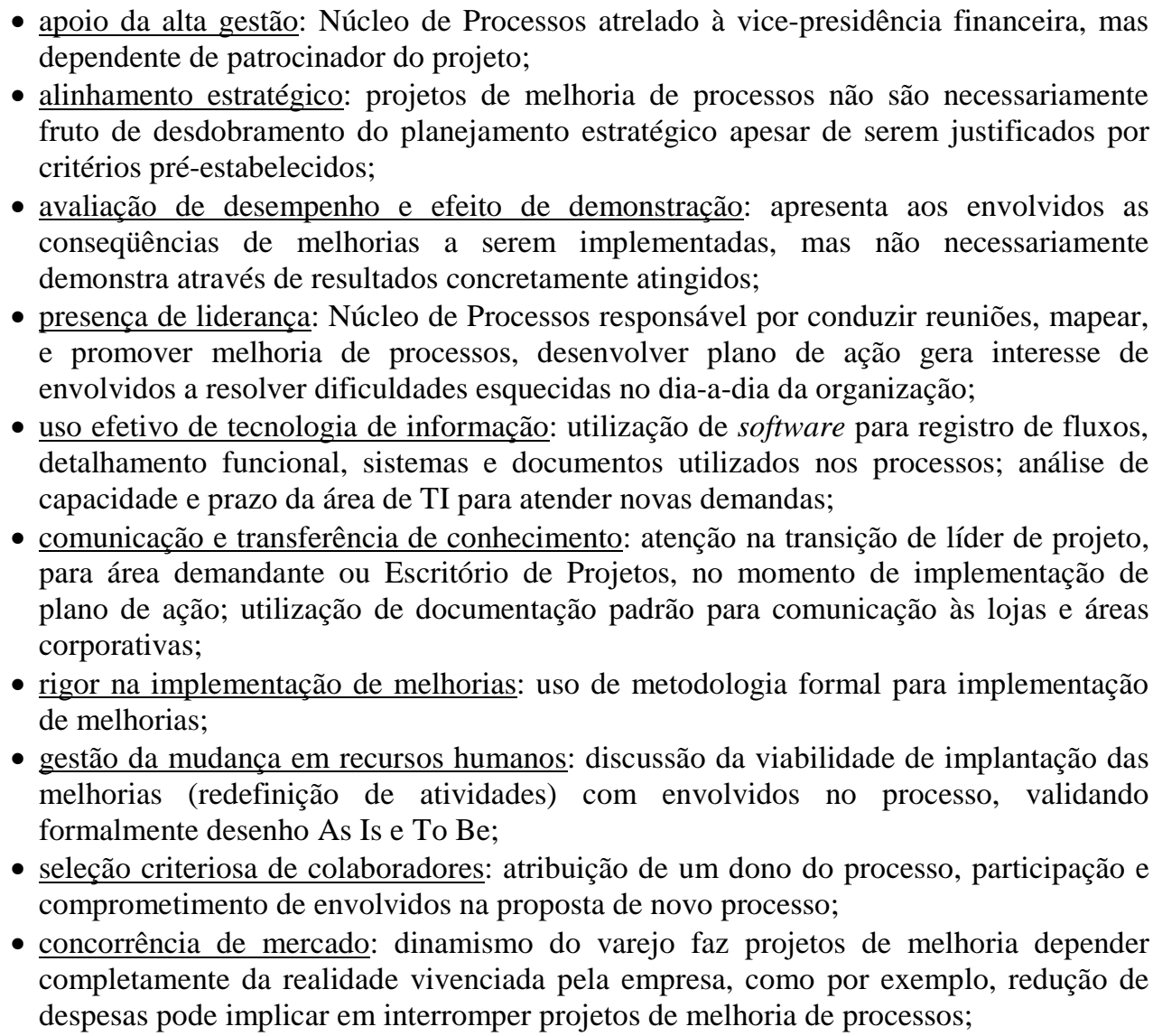 \\
\hline (3.5) Indicadores & $\begin{array}{l}\text { - não trabalha com identificação e definição de indicadores de desempenho de processo, } \\
\text { devidamente consistentes com a missão estabelecida para o mesmo; } \\
\text { - algumas vezes ocorre apenas a análise histórica de dados que possam refletir a(s) } \\
\text { melhoria(s) implantadas; } \\
\text { - não há indicadores claros e consistentes ligando os processos mapeados a objetivos } \\
\text { concretos e ou estratégicos da empresa. }\end{array}$ \\
\hline
\end{tabular}




\subsection{Empresa B}

\subsubsection{Estrutura e Funcionamento}

A empresa B, uma das líderes do setor de varejo não-alimentício brasileiro, é uma organização de estrutura familiar. Ligada diretamente a sua Presidência, a área de Qualidade e Processos existe desde 2005, abrangendo melhoria de processos, gestão de projetos e análise de riscos e de fraudes.

De início formalizados com a ferramenta $M S$ Visio, os processos da empresa B são atualmente documentados através do software ARIS-Toolset em conjunto com demais componentes do MS Office (PowerPoint, Excel e Word). A partir daí, os processos e políticas são divulgados a todos os colaboradores de loja e da sede por meio de correio eletrônico e de portal intranet.

\subsubsection{Metodologia para Melhoria de Processos}

A empresa B posiciona-se de forma contrária a qualquer iniciativa de reengenharia de processos. A melhoria de processos ocorre de forma contínua, porém a empresa B não aplica formalmente iniciativas estruturadas do tipo Lean Production, Kaizen ou Six Sigma, utilizando-se eventualmente de conceitos destas metodologias.

A melhoria de processos tem por referência, de um lado, ferramentas reconhecidamente comuns da Gestão da Qualidade, como fluxogramas, ciclo PDCA - Plan, Do, Check, Act -, desenho As Is e To Be, MIASP - Metodologia de Identificação, Análise e Solução de Problemas, etc e, de outro lado, conhecimentos prévios dos colaboradores da área de Qualidade e Processos com experiências externas à empresa. Assim, a empresa B se serve tanto de apanhado de conceitos e técnicas quanto de boas práticas de mercado, não se fixando metodologia específica. 


\subsubsection{Atuação para Abordagem de Processos}

A empresa $\mathrm{B}$ possui o conceito de processos claro para os colaboradores da área de Qualidade e Processos, assim como para Presidência da empresa, patrocinadora da área, porém não há definição formal. Atualmente, a área vivencia a expansão da abordagem de processos na empresa, principalmente dentro da alta hierarquia; já no caso dos colaboradores da organização como um todo, os conceitos ainda carecem de amadurecimento e de consolidação

A cultura de processos ainda não é amplamente divulgada e reconhecida pelos colaboradores. Nesse sentido, os colaboradores em geral têm conhecimento e valorizam, por exemplo, seguir normas e procedimentos, mas não têm a visão ampla de entendimento sobre a origem da necessidade daquela norma ou procedimento, entendendo somente o dever de cumprir a orientação.

A empresa B possui cadeia de valor estabelecida, porém está desenhada de forma "macro" e muito superficial. De um lado, os processos descritos em maior detalhe são ainda em sua grande maioria focados em atividades internas e administrativas da empresa. Isto se deve ao fato da atuação da área de Qualidade e Processos em toda a empresa ser direcionada a partir da visão da Presidência sobre os processos considerados críticos, custosos e, assim, de melhoria prioritária. Portanto, pressupõe-se uma tendência de atuação em projetos de melhoria de processos ligados a objetivos da empresa (por exemplo, redução de custos, implementação de sistemas de apoio à gestão, etc.), mas não necessariamente ligados ao cliente final ou à operação do negócio. Alguns exemplos de projetos de melhoria de processos é a implementação de sistemas controle de advertência, processo de admissão, solicitação e abertura de chamado de lojas, distribuição de uniformes e gestão de viagens corporativas (esses dois últimos serão descritos em item a seguir).

Por outro lado, para cada macro-processo da cadeia de valor existe um dono de processo atribuído, que na verdade são os grandes gestores das áreas. Esta atribuição é conhecida apenas no alto nível hierárquico da empresa (presidência, vice-presidência e diretoria). $\mathrm{O}$ dono do processo e seu papel ainda não são divulgados maciçamente para todos os níveis da empresa, cabendo à área de Qualidade e Processos massificar o conceito para outras áreas, divulgando-o nas interações de trabalho. Por exemplo, em reuniões do dia a dia junto com outras áreas, quando problemas são levantados, questiona-se aos presentes: "quem é o dono deste processo?" Assim, a empresa B realiza esforço em definir um dono do processo que 
esteja presente no dia a dia de sua atuação. Em princípio a própria área de Qualidade e Processos pode até liderar as alterações e implementações, dada possibilidade de enfraquecer resistências quando o processo é razoavelmente novo e diferente para os usuários. Porém, uma vez atingido certo nível de maturidade, é possível executar a transferência de dono para área responsável por aquele processo, procurando transferir também o conhecimento do negócio, os contatos, determinando os responsáveis para monitorar os indicadores e dar suporte aos usuários, a partir da análise do quadro de funcionários da nova área dona do processo.

Desde o início de atuação da área de Qualidade e Processos, a empresa B procura destacar sua relevância através da implementação de ganhos práticos nos processos. A área utiliza meios práticos e objetivos de coleta de informações, de obtenção de soluções, evitando burocracias ou medidas com alto custo. A coleta de informações a partir dos usuários dos processos (loja, sede, fornecedores, etc.) tem objetivo de extrair subsídios suficientes para estabelecer um fluxo do processo, sem grandes detalhes específicos, apenas para traçar um panorama geral da situação. Desta forma, procura obter, a partir de levantamento de histórico de dados e fatos, insumos para comparar as situações anterior e posterior à implementação de qualquer novo processo a ser implementado.

Nesse sentido, a área de Qualidade e Processos executa paciente trabalho ao obter fatos concretos das irregularidades e números para suportar a mudança do processo, apresentando a visão global do negócio e criando respaldos contra eventuais resistências.

Diante disso, a área de Qualidade e Processos sempre procura contatar usuários dos processos e realiza quantas reuniões sejam necessárias para se conseguirem ações simples, com resultados rápidos e eficazes, evitando-se a criação de resistências nas áreas. Assim, o novo processo procura ser planejado pensando-se no usuário do processo, entendendo suas necessidades e convidando-o a participar das decisões.

Esta preocupação é um dos fatores-chave para a conquista da confiança dos colaboradores para o projeto desenvolvido, assim como para transmitir o sentimento de participação conjunta. A estratégia adotada pela empresa B é definir os principais pontos com os principais usuários e apresentar a proposta pré-estabelecida para obter pequenas contribuições das demais áreas. Além disso, procura-se realizar previamente uma política de bastidores para coletar informações importantes ao processo e convencer as principais áreas sobre as mudanças necessárias. Finalmente, a área de Qualidade e Processos baseia-se também na experiência da equipe como um todo e procede eventualmente à realização de 
benchmarking simplificado em outras empresas - sem visitas in loco, somente contato via correio eletrônico ou telefone.

A empresa B possui de certa forma flexibilidade na aplicação de metodologia para melhoria de processos. Como a dinâmica do varejo exige que os resultados sejam apresentados de forma rápida, a atuação da área de Qualidade e Processos não segue necessariamente rigor metodológico fixo, bastando ser realizada de maneira estruturada e adaptada à necessidade. Em outros termos, a melhoria de processos não carece necessariamente de métodos complexos que mobilizem estatísticas, cálculos ou grandes estruturas. Ao atuar no varejo, são necessárias soluções práticas, de simples implementação, com ganhos rápidos, embasados por estudos históricos da realidade.

Por outro lado, a área de Qualidade e Processos atua com foco em planejar as ações para obter melhoria do processo. Independente das dificuldades encontradas, a equipe mantém o foco no resultado final esperado, procurando não se desviar das atividades previamente estabelecidas.

Além disso, a empresa B procura, sempre que possível, executar trabalho de parceria com fornecedores, sejam eles externos ou internos, para contornar um problema comum a grandes empresas: custo e tempo de espera na fila de pendências de desenvolvimento de sistemas da área de TI.

Pode-se afirmar que a área de Qualidade e Processos atua de forma isenta, no sentido de ter não apenas visão exterior ao processo, mas também liberdade de levantar questionamentos sobre atividades cotidianas entendidas como passíveis de melhoria.

Outro ponto importante é a aplicação de conceitos de processos proporcionalmente à maturidade da empresa no quesito conhecimento de qualidade. Mostra-se evidente que o fato de a área ser relativamente nova e de a empresa não possuir uma cultura de processos não permitem a utilização de conceitos técnicos elaborados, à frente daquilo que vive a empresa.

Vale ressaltar que toda demanda é vista como um processo e, portanto não é estático e fixo, podendo sofrer alterações. Durante o tempo em que atua sobre a demanda, a equipe de Qualidade e Processos procura monitorar a evolução do trabalho, revisando as atividades realizadas pelos usuários e ajustando o processo, quando necessário, para obter a formatação adequada.

Além disso, a empresa B escolhe e atribui indicadores que possibilitem monitorar constantemente o processo. Trata-se principalmente de indicadores que garantam criação de histórico de dados daquele processo de forma que o dono do processo possa realizar supervisão e acompanhamento de resultados conforme metas planejadas. Por outro lado, estes 
indicadores não são formalmente alinhados com a perspectiva estratégica da empresa ou ainda relacionados ao cliente final. Na verdade eles são estritamente para avaliar o desempenho do processo em si, de forma a permitir, se necessário, projetar eventos futuros como aumento de quadro de colaboradores, criação de nova área, aumento de lojas, análises por região, em suma, analisar potencial de melhoria contínua daquele processo.

\subsubsection{Exemplo de Projeto de Melhoria de Processos}

A partir da pesquisa de campo, o autor pode coletar informações a respeito de dois projetos (quadro 9) de melhoria de processos na empresa B: distribuição de uniformes (quadro 10) e gestão de viagens corporativas (quadro 11).

A empresa B não segue necessariamente rigor metodológico fixo, mas planeja e realiza ações de maneira estruturada e adaptada à necessidade. Desta forma não há etapas formalmente nominadas, porém para facilitar o entendimento de atuação, o autor propõe didaticamente as seguintes fases: identificação do problema, estabelecimento de plano de ação, desdobramento de resultados e formalização do processo. 
Quadro 9 - Exemplos de projetos de melhoria de processos na empresa B

\begin{tabular}{|c|c|c|}
\hline $\begin{array}{c}\text { Projeto de } \\
\text { Melhoria }\end{array}$ & Definição $^{2}$ & Histórico \\
\hline $\begin{array}{l}\text { Distribuição } \\
\text { de Uniformes }\end{array}$ & $\begin{array}{l}\text { Processos de distribuição de uniformes } \\
\text { de uso obrigatório e facultativo para } \\
\text { lojas, centrais de distribuição e setores } \\
\text { administrativo da sede, desde pedido } \\
\text { realizado via sistema até entrega ao } \\
\text { colaborador e retirada de material sem } \\
\text { condições de uso. }\end{array}$ & $\begin{array}{l}\text { A empresa B pratica, tradicionalmente, política de } \\
\text { distribuição de uniformes, de uso obrigatório em } \\
\text { certas áreas como vendas em lojas, centrais de } \\
\text { distribuição, e de uso facultativo em outras, } \\
\text { conforme determinação da diretoria, como no caso } \\
\text { do setor administrativo da sede. Conforme a } \\
\text { necessidade de cada loja ou área, que realiza pedido } \\
\text { via sistema, as peças (camisas, camisetas, jaquetas, } \\
\text { cardigãs, blusas, etc.) são distribuídas para todo o } \\
\text { Brasil. } \\
\text { Neste contexto, a diretoria executiva da empresa B } \\
\text { solicitou a área de Qualidade e Processos para que se } \\
\text { sanassem, sobretudo as causas do volumoso estoque } \\
\text { de material, no processo de distribuição de } \\
\text { uniformes. }\end{array}$ \\
\hline $\begin{array}{c}\text { Gestão de } \\
\text { Viagens } \\
\text { Corporativas }\end{array}$ & $\begin{array}{l}\text { Processos de gestão de viagens } \\
\text { corporativas desde a solicitação até a } \\
\text { compra de passagens, reserva de hotéis, } \\
\text { locação de veículos e demais trâmites } \\
\text { junto a agência de viagens prestadora de } \\
\text { serviços. }\end{array}$ & $\begin{array}{l}\text { A empresa B trabalha em parceria com uma agência } \\
\text { de viagens prestadora de serviços de cotação e } \\
\text { compra de passagens, reserva de hotéis, locação de } \\
\text { veículos e demais trâmites. Em geral, os pedidos de } \\
\text { viagens eram feitos à agência por correio eletrônico } \\
\text { ou telefone, de forma não-padronizada, sem controle } \\
\text { gerencial dos pedidos por parte da empresa B. } \\
\text { Assim, não havia área específica da empresa } \\
\text { responsável por fiscalizar e controlar a solicitação e a } \\
\text { execução das viagens como um todo; as informações } \\
\text { eram descentralizadas, cada área atuando à sua } \\
\text { maneira, sem referência a política comum redigida, } \\
\text { publicada, de livre acesso aos departamentos. }\end{array}$ \\
\hline
\end{tabular}

Fonte: Elaborado pelo autor

\footnotetext{
${ }^{2}$ Conforme já mencionado no quadro 4 do item 4.2
} 


\subsubsection{Distribuição de Uniformes}

A atuação da área de Qualidade e Processos se deu durante os anos de 2007 e de 2008. Focada em levantar causas, fazer proposição, modelagem, validação de soluções e implementar melhorias, optou-se, em razão da urgência exigida pela diretoria, não se formalizar fluxo atual (As Is) do processo, mas sim concentrar diretamente esforços na obtenção de informações para sugestão de novo modelo ( $T o \mathrm{Be}$ ). A diretoria executiva, patrocinadora do projeto, conferiu autonomia e autoridade para a área de Qualidade e Processos conduzir os estudos e convidar todas as áreas que julgasse necessárias para a resolução do problema.

\section{- Identificação do Problema}

Para identificar e analisar o problema, mesmo suas causas, a área de Qualidade e Processos optou primeiramente por fazer levantamento junto aos envolvidos, no intuito de entender como vinha ocorrendo a distribuição de uniformes. Tal estudo foi realizado de forma relativamente simples, evitando-se burocracias e custos para obtenção de dados, consultandose as áreas de negócio (Comercial, Operações Lojas e Depósito Almoxarifado) que vivenciavam pedido, distribuição, armazenagem, utilização e descarte dos uniformes. O objetivo principal desta etapa foi o de se verificarem as regiões do país afetadas, os colaboradores que tinham direito a este benefício, a maneira de realização dos pedidos, os números do processo, ou seja, tipo e durabilidade de produto, quantidade de peças recebidas por colaborador, valores, etc.

O resultado desta sondagem destacou o fornecimento de peças em quantidade acima do necessário, dada a durabilidade das mesmas, o que pode ser ilustrado pelo fato de um colaborador receber duas jaquetas ao ano, sendo que cada uma delas apresentava cinco anos de durabilidade, em condições normais de uso; consequentemente, grande volume de material se encontrava armazenado em estoque.

\section{- Estabelecimento de Plano de Ação}

Para se estabelecer plano de ação rápido e eficiente, optou-se por realizar teste piloto em trinta e três (33) lojas da região Sul do país, onde os valores envolvidos eram bastante significativos para, em seguida, estender a atuação e repensar o processo para toda a empresa. 
Conforme a necessidade, foram ainda realizadas reuniões com outras áreas como Marketing Padronização Visual, responsável pelo manual de identidade da marca e da utilização do logotipo da empresa; Jurídico Trabalhista, encarregada de analisar as resoluções legais; Recursos Humanos, incumbida da assistência às questões de departamento pessoal; além dos fornecedores de uniformes. Estabeleceu-se, em seguida, entendimento face à regionalização do país, questionando-se antigos costumes, atividades tradicionais há anos padronizadas, não questionadas pelo fato de serem hábitos (ex.: por que não fornecer apenas uma jaqueta por colaborador ao ano em vez de duas?). Em linhas gerais, tratava-se de valorizar o posicionamento da área de Qualidade e Processos como ponto de vista exterior, não-sujeito aos vícios daqueles que vivenciam a rotina do dia a dia.

A área de Qualidade e Processos propôs, assim, a redução de quantidades de uniformes e de frequiência de pedidos, a partir de análise minuciosa da efetiva necessidade dos colaboradores. Em seguida, os valores foram ajustados e alinhados com as principais áreas envolvidas para finalmente serem validados junto à diretoria executiva. Uma vez aprovada a solução, o sistema de pedido foi parametrizado conforme as novas definições.

O resultado passou a ser evidente nos meses seguintes, tendo-se constatada redução de cerca de $65 \%$ nos custos com uniformes para aquela região. O sucesso dos resultados com a realização deste teste piloto na região Sul incentivou a replicação das ações e o estudo de melhorias para toda a empresa, no quesito utilização de uniformes.

\section{- Desdobramento de Resultados}

No caso das lojas, a área de Qualidade e Processos optou, primeiramente, por entender os tipos de uniformes disponíveis na empresa, tendo contatado o setor de Depósito Almoxarifado, além de ter realizado junto ao setor Comercial Compras levantamento de quantidades necessárias de uniformes, por cargo e por freqüência, para se realizarem pedidos. Além disso, em parceria com a área de Operações Loja e com o fornecedor, chegou-se à quantidade necessária de uniforme, sobretudo de camisas, por colaborador. No caso dos departamentos da corporação, procurou-se questionar a necessidade de utilização de uniformes, de manter-se um padrão, dado que não havia contato direto com cliente.

Além disso, constatou-se que o controle de devolução de uniformes, em casos de desligamento, transferência de área, ou substituição de uniforme impróprio para uso, não era totalmente eficaz, havendo, por exemplo, possibilidade de ex-funcionários permanecerem com seus uniformes, o que representava risco para a imagem da empresa. 
O foco da área de Qualidade e Processos, neste caso, foi a obtenção de resultados rápidos a partir de medidas simples e eficazes. Desta forma, optou-se pela revisão das quantidades de peças por colaborador, parametrizadas no sistema, e pela implantação de procedimento de recepção e devolução de uniformes. Em resumo este último consistia em determinar que todo colaborador preenchesse e assinasse um termo de recebimento de uniforme, de maneira a que se comprometesse a mantê-lo em bom estado e a devolvê-lo nos casos de desligamento, transferência de área, ou substituição por outra peça. Da mesma forma, em caso de devolução, o colaborador deveria registrar estas informações no referido termo, cabendo ao gestor da área fiscalizar, controlar e monitorar o fornecimento e a devolução das peças.

\section{- Formalização do Processo}

Após validação da diretoria executiva, elaborou-se, como complemento, política informativa do procedimento de recebimento e de devolução de uniformes, da necessidade de homogeneização de cores, da realização de pedidos sob a condição de esgotamento do estoque corrente e do estabelecimento da cor branca como padrão para camisas. Desta forma, a empresa ganhou maior poder de negociação em grandes volumes e induziu à redução de estoques.

Durante o processo de elaboração da política de recebimento, utilização e devolução de uniformes, foi também abordado o destino final das peças devolvidas. Como solução, contatou-se a área de Benefícios, responsável por prestar assistência social a entidades locais, para se avaliar a possibilidade de reutilização dos materiais. Após estudo em amostras, constatou-se que o logotipo da empresa poderia ser removido e substituído por outro, bordado, permitindo que as peças fossem direcionadas para doação a comunidades desfavorecidas da região.

O processo finalizado de distribuição de uniformes pode ser representado pela figura a seguir: 


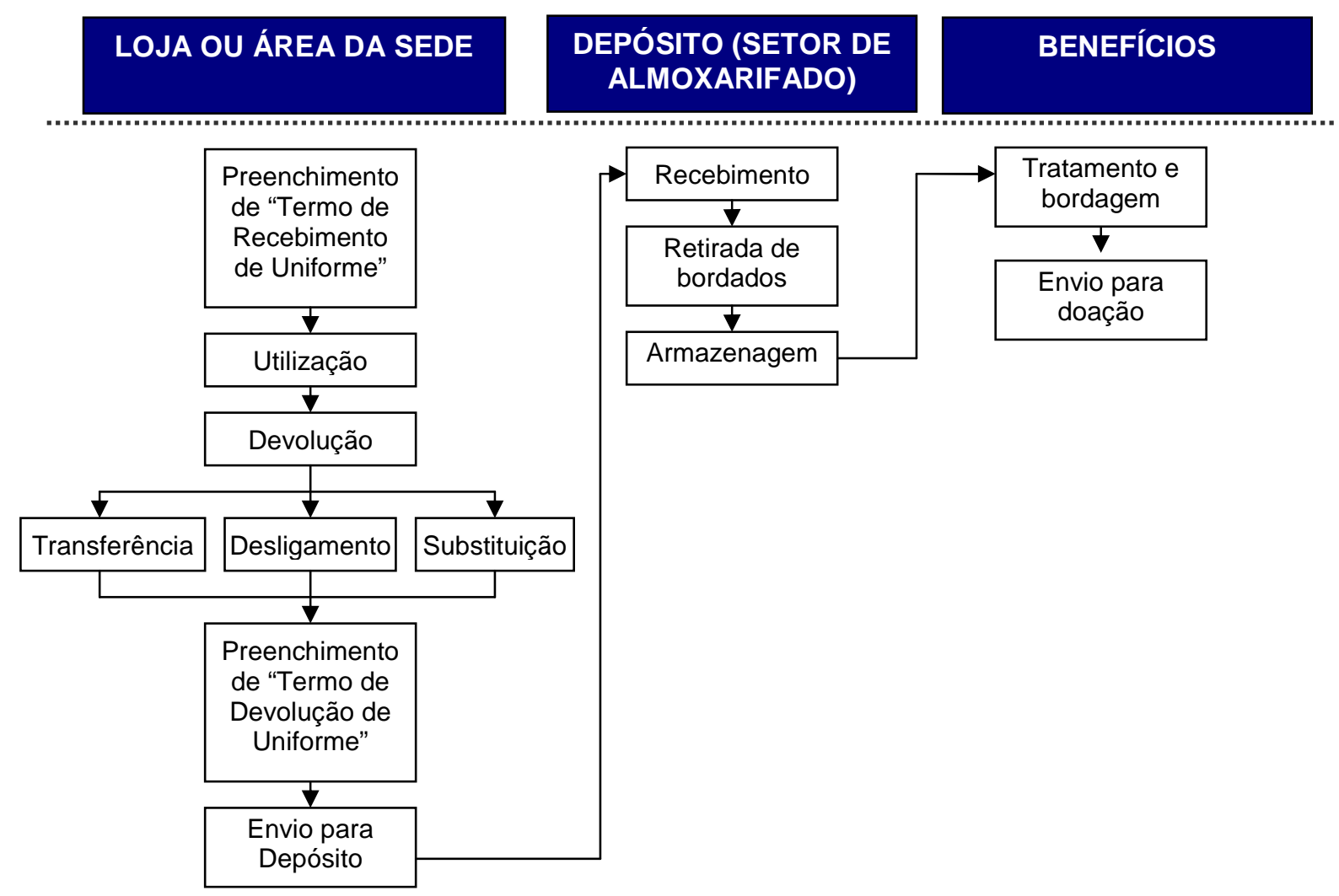

Figura 7- As etapas do processo de "Distribuição de uniformes" (Fonte: elaborado pelo autor)

A área de Qualidade e Processos publicou a política no portal da empresa e informou por correio eletrônico os gestores, incumbindo-os de multiplicar a informação a suas equipes. Alguns meses depois, foi publicado em periódico interno reportagem sobre o assunto, no intuito de relembrar os colaboradores da relevância do processo.

No caso de áreas corporativas, ou seja, fora das lojas, optou-se por implementar a solução de forma a não denegrir a imagem da empresa perante os funcionários, provavelmente inquietos com a perda do benefício do uniforme, talvez desmotivados diante do custo do uniforme, e preocupações semelhantes. Desta forma, houve cuidado para não se criar uma obrigação, mas sim um incentivo indireto não intencional aos colaboradores para que deixassem de utilizar uniforme, limitando-se as quantidades, verificando-se departamentos mais favoráveis à não-utilização, controlando-se parâmetros no sistema de pedido, etc.

De certa maneira, a repercussão junto às áreas e lojas foi positiva, uma vez que houve padronização dos uniformes e redução de custos, com a diminuição de estoques e volume de compras, sem que se criasse prejuízo para os colaboradores no desempenho de suas 
atividades. Além disso, o reaproveitamento de peças de uniforme colaborou para destacar a imagem da empresa e atender às entidades sociais parceiras.

A área de Qualidade e Processos, por sua vez, tornou-se referência no assunto aos olhos da empresa, tendo assumido papel de dona do processo. Com a divulgação do trabalho realizado e dos resultados atingidos na revista interna, Qualidade e Processos publicou suas atividades para demais áreas, tendo destacado sua atuação para a empresa como um todo.

No entanto, o processo de distribuição de uniformes não possui ainda indicadores claros, existindo apenas levantamento dos principais números do processo, monitorados pelas áreas, como o controle de quantidades, realizado periodicamente pelo Comercial Compras. Por outro lado, destaca-se a importância dos pontos de controles estabelecidos "automaticamente" no processo, seja através da parametrização do sistema de pedido, com as informações da política de distribuição de uniformes, seja através do gestor fiscalizador da devolução e da troca de uniformes, além do arquivamento dos termos de recebimento e devolução.

Após transição de dono do processo para área outra que vivencia operacionalmente a distribuição de uniformes, pretende-se criar indicadores e estabelecer outros controles no sistema, para melhor acompanhamento das atividades. Cogita-se, por exemplo, transferir o termo de devolução, atualmente arquivado na pasta do funcionário, para banco de dados, o que permitiria análise e extração de relatórios. Evidentemente, existe foco da área de Qualidade e Processos em executar esta passagem de bastão da maneira mais suave possível, dando atenção para que o novo dono seja treinado e comprometido a buscar a contínua melhoria do processo. 
Quadro 10 - Exemplo de melhoria do processo de distribuição de uniformes

\begin{tabular}{|c|c|c|c|}
\hline $\begin{array}{l}\text { 1. Identificação do } \\
\text { Problema }\end{array}$ & 2. Estabelecimento e & $\begin{array}{l}\text { 3. Desdobramento } \\
\text { de Resultados }\end{array}$ & $\begin{array}{l}\text { 4. Formalização } \\
\text { do Processo }\end{array}$ \\
\hline $\begin{array}{l}\text { - levantamento junto aos envolvidos } \\
\text { (Comercial, Operações Lojas e } \\
\text { Depósito Almoxarifado) que } \\
\text { vivenciavam pedido, distribuição, } \\
\text { armazenagem, utilização e descarte } \\
\text { dos uniformes. } \\
\text { - o resultado desta sondagem } \\
\text { destacou o fornecimento de peças } \\
\text { em quantidade acima do necessário, } \\
\text { dada a durabilidade das mesmas, } \\
\text { consequentemente, grande volume } \\
\text { de material se encontrava } \\
\text { armazenado em estoque. }\end{array}$ & $\begin{array}{l}\text { - teste piloto em trinta e três (33) lojas da região } \\
\text { Sul do país; realização de reuniões com outras } \\
\text { áreas (Marketing Padronização Visual Jurídico } \\
\text { Trabalhista Recursos Humanos), além dos } \\
\text { fornecedores de uniformes; } \\
\text { - questionamento de antigos costumes e } \\
\text { atividades considerados hábitos; } \\
\text { valorização do posicionamento da área de } \\
\text { Qualidade e Processos como facilitador } \\
\text { externo; } \\
\text { proposta alinhada com as principais áreas } \\
\text { envolvidas para reduzir quantidades de } \\
\text { uniformes e frequiência de pedidos, a partir de } \\
\text { análise minuciosa da efetiva necessidade dos } \\
\text { colaboradores; } \\
\text { parametrização de sistema de pedido conforme } \\
\text { novas definições; constatou-se redução de } \\
\text { cerca de } 65 \% \text { nos custos com uniformes para } \\
\text { aquela região. }\end{array}$ & $\begin{array}{l}\text { - replicação de ações para toda } \\
\text { empresa; no caso de Lojas definição } \\
\text { conjunta (Depósito Almoxarifado, } \\
\text { Comercial Compras, Operações Loja } \\
\text { e fornecedor) dos tipos e quantidades } \\
\text { necessárias de uniformes, por cargo e } \\
\text { por freqüência, para se realizarem } \\
\text { pedidos; } \\
\text { - no caso dos departamentos da } \\
\text { corporação, procurou-se questionar a } \\
\text { necessidade de utilização de } \\
\text { uniformes, de manter-se um padrão, } \\
\text { dado que não havia contato direto } \\
\text { com cliente; além disso, implantação } \\
\text { de procedimento de recepção e } \\
\text { devolução de uniformes em casos de } \\
\text { desligamento, transferência de área, } \\
\text { ou substituiçãa de uniforme impróprio } \\
\text { para uso. }\end{array}$ & $\begin{array}{l}\text { - após validação da diretoria executiva, } \\
\text { publicação via portal da empresa, periódico } \\
\text { interno e correio eletrônico de política } \\
\text { informativa do procedimento de recebimento e } \\
\text { de devolução de uniformes, da realização de } \\
\text { pedidos sob a condição de esgotamento do } \\
\text { estoque corrente e do estabelecimento da cor } \\
\text { branca como padrão para camisas. Empresa } \\
\text { ganhou maior poder de negociação em grandes } \\
\text { volumes e induziu à redução de estoques. } \\
\text { - definição de reutilizar peças devolvidas (área de } \\
\text { Benefícios, responsável por prestar assistência } \\
\text { social a comunidades desfavorecidas da região), } \\
\text { direcionando-as para doação. } \\
\text { no caso de áreas corporativas, houve incentivo } \\
\text { indireto não intencional aos colaboradores para } \\
\text { que deixassem de utilizar uniforme, limitando- } \\
\text { se as quantidades, verificando-se departamentos } \\
\text { mais favoráveis à não-utilização, controlando-se } \\
\text { parâmetros no sistema de pedido, etc. } \\
\text { a área de Qualidade e Processos, por sua vez, } \\
\text { tornou-se referência no assunto aos olhos da } \\
\text { empresa, tendo assumido papel de dona do } \\
\text { processo. Após transição de dono do processo } \\
\text { (passagem de bastão permitindo que novo dono } \\
\text { seja treinado e comprometido) para área outra } \\
\text { que vivencia operacionalmente a distribuição de } \\
\text { uniformes, pretende-se criar indicadores (há } \\
\text { apenas levantamento dos principais números } \\
\text { monitorados pelas áreas) e estabelecer outros } \\
\text { controles no sistema, para melhor } \\
\text { acompanhamento das atividades. Cogita-se, por } \\
\text { exemplo, transferir-se o termo de devolução, } \\
\text { atualmente arquivado na pasta do funcionário, } \\
\text { para banco de dados, o que permitiria análise e } \\
\text { extraccão de relatórios. }\end{array}$ \\
\hline
\end{tabular}




\subsubsection{Gestão de Viagens Corporativas}

Em meados de 2007, a área de Qualidade e Processos foi acionada pela diretoria executiva, preocupada em gerir as viagens corporativas.

A área de Qualidade e Processos atuou nesta demanda por meio de um Analista de Processos supervisionado pela gerência, com o objetivo de mapear o processo corrente (As $I s)$, modelar nova solução com melhorias ( $T o B e$ ), além de elaborar e publicar eventuais documentações necessárias.

\section{- Identificação do Problema}

A área de Qualidade e Processos decidiu levantar informações referentes ao processo, tendo composto grupo de trabalho formado pelos principais usuários envolvidos. Assim, foram realizadas reuniões com diretores e gerentes de loja, secretárias e responsáveis pela parte administrativa das áreas da sede, que vivenciavam as atividades em questão em seu dia a dia, a fim de se obterem os principais dados para posterior padronização do processo.

Além da agência de viagens responsável por fornecer números do processo como quantidade de viagens, gastos, frequiência, foram contatadas as áreas de Marketing, patrocinadora do projeto, pelo fato de se tratar de empresa familiar cujo diretor era filho do dono, Jurídico, para dar suporte legal às decisões tomadas, Custos, para fornecer informações cadastrais, RH, para entendimento da base de cargos e de colaboradores envolvidos no processo, e Operações Loja, principal usuária de viagens.

A área de Qualidade e Processos, por sua vez, elaborou fluxos das principais atividades (As Is) como, por exemplo, o processo de solicitação de viagens, representado em etapas conforme a figura seguinte: 


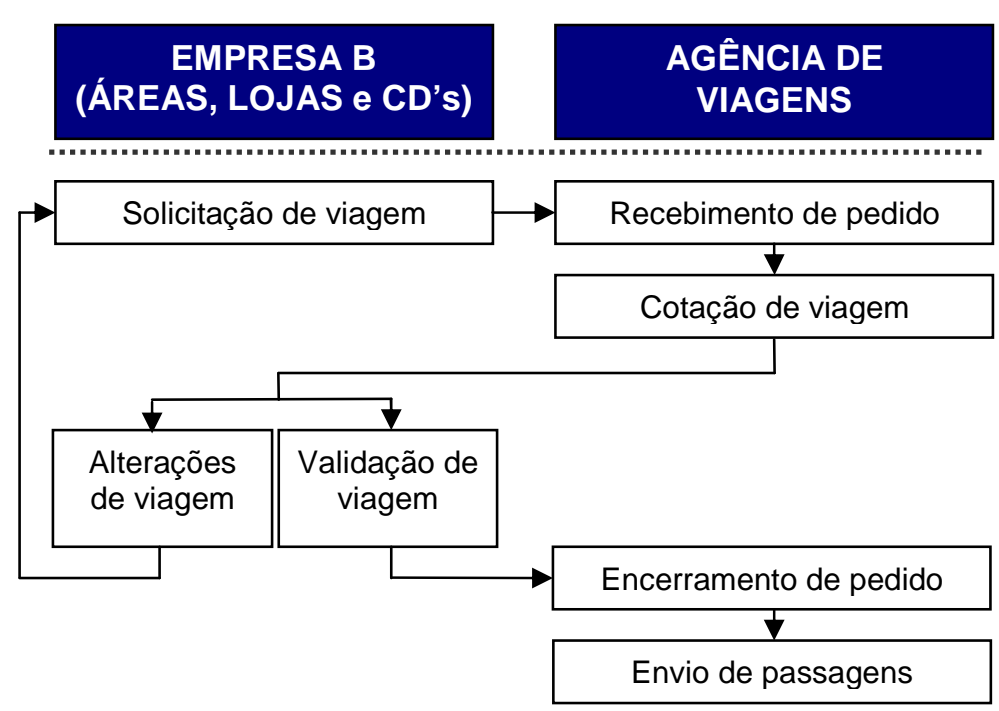

Figura 8 - As etapas do processo "Solicitação de viagens" (Fonte: elaborado pelo autor)

As reuniões de levantamento de informações e os fluxos elaborados permitiram colocar em evidência os seguintes fatos:

- as solicitações de viagens eram realizadas manualmente (correio eletrônico ou telefone) pelas próprias áreas, não havendo procedimentos e nem controles obrigatórios;

- a cotação de viagens era feita pela empresa B e não pela agência de viagens, o que prolongava o tempo de solicitação de passagens, além de provocar retrabalho;

- não havia padrão de acompanhamento de despesas; a carência de visão detalhada e aprofundada dos gastos realizados com viagens gerava, por sua vez, dificuldade de se obterem relatórios customizados e específicos por área;

- os parâmetros para alocação de viajante, como tipos de hotéis, categoria de quartos, tempo de permanência, não estavam pré-definidos, sendo as viagens autorizadas pela própria área, conforme limites negociados diretamente com a presidência;

- os limites de despesas como alimentação, lavanderia etc. não estavam claramente definidos por cargo, nem padronizados para todos departamentos, o que dava margem a excessos;

- os gastos realizados em viagens eram fiscalizados de forma imprópria, não havendo necessariamente um controle direto ligado ao orçamento da área; 
- havia grande volume de solicitações, o que aumentava a dificuldade de se conciliarem valores.

O resultado deste trabalho evidenciou a necessidade de se: (i) adequar as solicitações de acordo com política formalizada de gestão de viagens corporativas disponível a todos usuários e; (ii) elaborar controle padrão e canal único de comunicação para as solicitações de passagens aéreas e rodoviárias, hospedagem e locação de veículos.

Desta forma, seria possível implantar mecanismos para a construção de base de dados confiável, com informações de solicitação (demandante, área, objetivo, justificativa, forma de pedido, urgência), análise (critérios, limites) e autorização (aprovador, nível de alçada, etc.).

\section{- Estabelecimento e Execução de Plano de Ação}

Primeiramente, para se definir a política de gestão de viagens corporativas, a área de Qualidade e Processos elaborou proposta conforme entendimento com as áreas e com a agência de viagens, tendo levado também em consideração o histórico da empresa e benchmarking de práticas de mercado.

Diante disso, constatou-se a necessidade de se estabelecer critério padrão para escolha de classes em vôos e tipo de hospedagens de acordo com nível hierárquico dos colaboradores e com a viagem - distância, duração da missão, etc.

Assim, a área de Qualidade e Processos teve a responsabilidade de elaborar, juntamente com RH, proposta de tabela de classes que apresentava os tipos de acomodações e de vôos disponíveis conforme os cargos dos colaboradores. Foram estabelecidos níveis de alçada de aprovação para cada uma das cinco classes: Diretoria, Gerência, Coordenação, Analistas e demais cargos.

Em seguida, a proposta passou pela avaliação do Jurídico e das diretorias das áreas para propor eventuais ajustes. Vale destacar, neste momento, que para diminuir efeitos de futuras resistências de aceitação, foi solicitada a participação dos diretores mais afetados pela política, com a finalidade de se captarem comentários construtivos e fazê-los se sentirem parte do processo. A ideia era apresentar regras parcialmente definidas, buscando a participação dos usuários do processo, mantendo o foco em suas necessidades, e não necessariamente seus desejos.

Finalmente, a proposta foi validada pela diretoria executiva da empresa, que avaliou os critérios de viagem, hospedagem, locação de veículos e consumo adotados conforme cargo.

Para informar diretores e áreas sobre a nova política, a área de Qualidade e Processos, naquele momento responsável pelo processo, contando com apoio geral da área de 
Comunicação Interna, realizou comunicado oficial para a empresa através de correio eletrônico padronizado, mural de comunicação e publicação no portal da intranet. Assim, o trabalho desenvolvido permitiu a formalização de todas variáveis, implantando-se controles e definindo-se claramente limites de gastos com viagens.

Para se elaborar controle padrão e canal único de comunicação para as solicitações de viagens, optou-se, primeiramente, em manter o foco nos aspectos relevantes buscando melhorias nos casos mais recorrentes e geradores de custos expressivos para empresa B: a solicitação de viagens aéreas e a hospedagem.

Diante do exposto, percebeu-se a necessidade de criação de sistema de controle de solicitações e cotações de hospedagem e passagens aéreas. Em reuniões de alinhamento com a área de Qualidade e Processos, a agência de viagens se ofereceu, com o objetivo de estreitar e fortalecer a parceria entre as empresas, para financiar o desenvolvimento e implementação do sistema, uma vez que a empresa B é sua principal cliente. Além disso, a empresa B tem alta demanda de outras áreas para área de TI, sendo sua prioridade diferente de Qualidade e Processos.

As etapas para implantação do sistema são apresentadas conforme a figura seguinte:

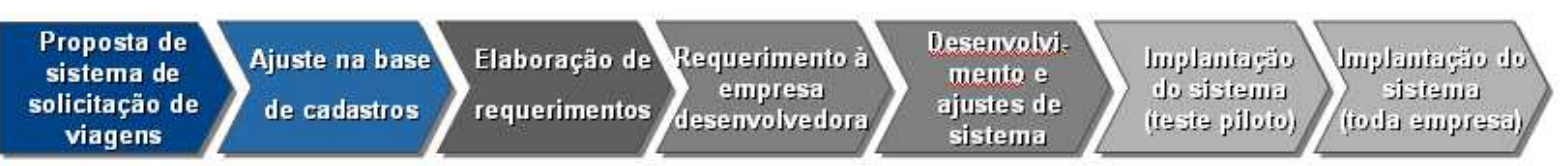

Figura 9 - As etapas para implantação do sistema na gestão de viagens corporativas (Fonte: elaborado pelo autor)

- proposta de sistema de solicitação de viagens: desenho e apresentação de proposta de agência de viagens elaborar, em conjunto com empresa desenvolvedora, sistema para solicitação de viagens;

- ajuste na base de cadastros: atualização de informações de todos colaboradores da empresa, tanto contratados quanto demitidos, para inclusão de dados no sistema;

- elaboração de requerimentos: implica definir requisitos quanto às informações da política de viagens corporativas, parâmetros do sistema e validação junto a áreas envolvidas e à agência de viagens;

- requerimento à empresa desenvolvedora: apresentação dos campos do sistema, de forma a permitir a rastreabilidade das solicitações e a elaboração de relatórios gerenciais para controle e acompanhamento; 
- desenvolvimento e ajustes de sistema: elaboração de sistema conforme os requerimentos anteriores e inclusão de base de dados adequada de funcionários, de filiais da empresa e de motivos de viagens, coletados junto às áreas, além dos níveis de classe do sistema;

- implantação do sistema (teste piloto): realização de teste piloto em ambiente de simulação do sistema junto com as áreas de Qualidade e Processos, Marketing, Telecomunicações, Departamento de Crédito Central, Auditoria e RH;

- implantação do sistema (toda empresa): confecção de planejamento e de cronograma detalhado para implantação do sistema em toda empresa, incluindose treinamento das equipes - convite, apresentações, capacitações, orientações pré e pós-treinamento, testes práticos e simulações - , além de centralização de ocorrências e solução de dúvidas.

\section{- Desdobramento de Resultados}

Os resultados da implantação de sistema e criação de política de gestão de viagens corporativas ganharam destaque, o que permitiu:

- padronizar a forma de realizar solicitação, cotação e validação de viagens para a agência através do portal da empresa;

- aumentar a agilidade em pedidos e reservas, tornando mais eficaz a comunicação;

- estruturar solicitações a cargo da agência de viagens, conforme política definida, evitando privilégios, devido à "pressão" do solicitante;

- reduzir custo com telefonia e desperdício de tempo na realização de pedidos de viagens, como exemplifica a diminuição de 70 dias na preparação de trâmites de viagens em evento anual de vendas, com participação de colaboradores de todo Brasil;

- criar controles e relatórios gerenciais padrões a partir de base de dados confiável, o que permitiu "rastrear" viagens e decisões tomadas;

- acompanhar solicitações de CD's regionais, através do direcionamento de custos para um único $\mathrm{CD}$;

- gerenciar exceções de pedidos realizados com urgência, evitando viagens onerosas para empresa por mera escolha do viajante ou por desconhecimento das melhores oportunidades; 
Além disso, com base no desdobramento da demanda, percebeu-se a possibilidade de se economizar realizando parcerias com companhias aéreas, ou seja, acordo de preferência permitindo desconto em passagens aéreas a partir de gastos mínimos estipulados entre as partes.

Finalmente, houve a divulgação da área de Qualidade e Processos para outras áreas da empresa, através de correio eletrônico, portal e revista institucional, permitindo associar seu foco de atuação com a melhoria de processos.

\section{- Formalização do Processo}

O processo de gestão de viagens corporativas não possuía dono formalmente atribuído, cabendo naturalmente à área de Qualidade e Processos exercer tal função durante a elaboração de proposta e implementação do sistema. Isto implicou no acompanhamento da homologação de sistema e na correção de eventuais erros. As soluções foram propostas gradativamente, sobretudo após implantação do sistema, com a participação de diversas áreas proponentes de eventuais alterações.

Após certo período, a gestão de viagens corporativas adquiriu maturidade para os usuários, o que permitiu à área de Qualidade e Processos encaminhar a transferência de dono do processo. Apesar da simplicidade do processo, sua gestão é complexa devido à série de detalhes e peculiaridades. Preocupado com a condução das responsabilidades pelo novo dono, a área de Qualidade e Processos empenhou esforços para comunicar, treinar e conquistar o comprometimento da equipe de Administração de Serviços Gerais, detentora do papel.

Além disso, apesar da comunicação por correio eletrônico aos gestores sobre a mudança de dono de processo, houve casos de áreas não tomarem conhecimento do fato por falta de repasse da informação para demais colaboradores. Por conseguinte, coube à área de Qualidade e Processos executar política de bastidores e perseverar no paciente trabalho de relembrar as áreas sobre o novo dono do processo.

Vale ressaltar que a implantação do sistema, apesar do apoio da presidência, apresentou certa resistência dos colaboradores a aceitarem mudanças. Este fato era naturalmente esperado, tratando-se da cultura familiar da empresa, em que os funcionários eram habituados a realizar pedidos de certa maneira. Para superar estas dificuldades, foi realizado treinamento intenso e divulgação, via portal e correio eletrônico, do novo sistema aos colaboradores. Além disso, estabeleceu-se parceria com agência de viagens para informar aqueles que não faziam pedidos via sistema. Desta forma, Qualidade e Processos pode executar trabalho pontual junto ao usuário para entender as dificuldades e resolver problemas como ajuste do 
sistema de pedido ao sistema operacional da máquina do usuário, falta de conhecimento para utilizar o sistema, inadequação de parâmetros de visualização, etc. Os ajustes de sistema eram realizados de forma gradativa, necessitando serem testados e homologados, tomando certo tempo aos envolvidos.

Cabe ainda insistir que as decisões tomadas em reuniões eram registradas em ata como deliberações a serem monitoradas pela área de Qualidade e Processos. Desta forma, a área tinha a responsabilidade de realizar o gerenciamento do projeto e contatar as demais áreas para verificar e incentivar a execução das atividades. Destaca-se assim o papel de Qualidade e Processos como facilitadora na promoção das melhorias do processo.

Para formalizar e explicar a utilização da ferramenta de solicitação de viagens, a área de Qualidade e Processos elaborou manual do usuário, contemplando os principais comandos, procedimentos de pedidos e perguntas mais freqüentes.

É importante colocar em evidência a preocupação em implantar indicadores automáticos gerados pelo próprio sistema, possibilitando comparar gastos realizados e orçados pelas áreas. Desta forma, houve a criação de histórico de despesas (a partir de 2007) permitindo melhor previsibilidade e calibragem do processo. Além disso, estes indicadores são de fácil acesso, com identificação visual no próprio sistema, permitindo elaboração de relatórios customizados conforme parâmetros definidos - prazo, área da empresa, período, etc. Estes relatórios do sistema foram validados pela diretoria executiva, baseados nos controles que os usuários eram habituados a fazer, como relatórios mensais, sintético e analítico, controle de área solicitante, custos, motivos, período.

Finalmente, pode-se afirmar que o sucesso de implantação da política de gestão de viagens corporativas ocorreu devido ao envolvimento e ao comprometimento de áreas fundamentais na execução do processo e ao esforço de se pensar previamente em todas variáveis, planejando as possíveis ações. 
Quadro 11 - Exemplo de melhoria de processo de gestão de viagens corporativas

\section{Identificação do Problema}

levantamento junto aos usuários (diretores e gerentes de loja, secretárias e responsáveis pela parte administrativa das áreas da sede, agência de viagens, áreas de Marketing, Jurídico, Custos, RH Operações Loja) e elaboração de fluxos das atividades (As Is).

- Isto evidenciou a necessidade de se:

(i) adequar as solicitações de acordo com política formalizad de gestão de viagens corporativas disponível a todos usuários e;

(ii) elaborar controle padrão e canal único de comunicação para as solicitações de passagens aérea rodoviárias, hospedagem locação de veículos.

- desta forma, seria possível implantar mecanismos para construção de base de dados confiável, com informações de solicitação (demandante, área, objetivo, justificativa, forma de pedido, urgência), análise (critérios, limites) e autorização (aprovador, nível de alçada, etc.). Be) validada por todos, estabelecendo-se critério padrão para escolha de classes em vôos e tipo de hospedagens conforme nível hierárquico dos colaboradores e viagem distância, duração da missão, etc.; além de estabelecer níveis de alçada de aprovação.

- solicitada a participação dos diretores afetados pela política, diminuindo efeitos de futuras resistências de aceitação, obtendo-se comentários construtivos e fazendo-os sentirem-se parte do processo.

- comunicação oficial para empresa através de correio eletrônico padronizado, mural de comunicação e publicação no portal da intranet.

- através de parceria com agência de viagens, foi implementado de forma estruturada sistema de controle de solicitações e cotações de hospedagem e passagens aéreas.

\section{Desdobramento de Resultados}

a implantação de sistema e criação de política de gestão de viagens corporativas:

padronizaram a forma de realizar solicitação, cotação e validação de viagens através do portal da empresa;

aumentaram a agilidade em pedidos e reservas;

reduziram custo com telefonia e desperdício de tempo; criaram controles e relatórios gerenciais padrões;

permitiram gerenciar exceções de pedidos realizados com urgência, evitando viagens onerosas por mera escolha do viajante além de economizar realizando parcerias com companhias aéreas.

- finalmente, houve divulgação da área de Qualidade e Processos, através de correio eletrônico, portal e revista institucional, permitindo associar seu foco de atuação com a melhoria de processos.

\section{Formalização do Processo}

- após o processo adquirir maturidade, Qualidade e Processos encaminhou transferência de dono do processo empenhando esforços para comunicar, treinar e conquistar comprometimento da equipe de Administração de Serviços Gerais, detentora do papel.

- para superar resistência dos colaboradores, foi realizado treinamento e divulgação, via portal e correio eletrônico, do novo sistema aos colaboradores.

as decisões tomadas em reuniões eram registradas em ata como deliberações a serem monitoradas pela área de Qualidade e Processos, destacando seu papel de facilitador entre as áreas.

- para formalizar e explicar a utilização da ferramenta de solicitação de viagens, elaborouse manual do usuário, contemplando procedimentos de pedidos e perguntas mais freqüentes.

- implantaram-se também indicadores de fácil acesso, com identificação visual no próprio sistema, gerados automaticamente, possibilitando comparar gastos realizados e orçados através de relatórios customizados conforme parâmetros definidos - prazo, área da empresa, período, etc.

- pode-se destacar como sucesso para melhoria deste processo o envolvimento e comprometimento de áreas fundamentais em sua execução e o esforço de se pensar previamente em todas variáveis, planejando possíveis ações. 


\subsubsection{Análise do Caso B}

Assim como para o caso anterior, o autor pode preparar para o caso B painel de dados (quadro 12) relacionando itens relevantes da literatura com as fontes de evidência, buscando destacar pontos para responder à pergunta de pesquisa.

Quadro 12 - Conceitos da literatura e análise do caso B

\begin{tabular}{|c|c|}
\hline $\begin{array}{c}\text { Conceitos da } \\
\text { Literatura }\end{array}$ & Análise do Caso B \\
\hline (3.1) Processos & $\begin{array}{l}\text { - não há definição formal de processo } \\
\text { - conceito de processo é claro para Presidência, e para área de Qualidade e Processos } \\
\text { diferente das demais áreas em que carece de amadurecimento e de consolidação; } \\
\text { - processos a serem melhorados são escolhidos conforme orientação da Presidência, } \\
\text { havendo tendência de atuar naqueles ligados a objetivos da empresa (por exemplo, } \\
\text { redução de custos), mas não necessariamente ligados ao cliente final; } \\
\text { - possui cadeia de valor mapeada superficialmente, sendo maior atuação em processos } \\
\text { administrativos, não necessariamente ligados diretamente ao negócio; } \\
\text { - divulgação de processos via email e intranet da empresa; }\end{array}$ \\
\hline $\begin{array}{l}\text { (3.2) Gestão por } \\
\text { processos }\end{array}$ & $\begin{array}{l}\text { - ações de melhoria eficazes a partir de atuação estruturada e planejada da equipe de } \\
\text { Qualidade e Processos, evidenciando para áreas impacto de suas atividades entre si; } \\
\text { - independente das dificuldades encontradas, foco no resultado final esperado, } \\
\text { procurando não se desviar das atividades previamente estabelecidas; } \\
\text { - colaboradores seguem normas e procedimentos estabelecidos, mas não tem a visão } \\
\text { ampla de entendimento sobre a origem da necessidade daquela norma ou procedimento; } \\
\text { - em projetos de melhoria de processos, ocorre definição de melhorias com principais } \\
\text { usuários e apresenta-se a proposta pré-estabelecida para obter pequenas contribuições } \\
\text { das demais áreas, criando sentimento de participação conjunta. }\end{array}$ \\
\hline $\begin{array}{l}\text { (3.3) Melhoria de } \\
\text { processos }\end{array}$ & $\begin{array}{l}\text { - foco em melhoria de processos contínua, sem ter vivenciado iniciativas estruturadas do } \\
\text { tipo Lean Production, Kaizen, Six Sigma ou ainda reengenharia de processos; } \\
\text { - coleta de informações extraindo subsídios suficientes para estabelecer panorama geral } \\
\text { da situação, através de fluxo do processo, sem detalhes específicos; } \\
\text { - levantamento de histórico de dados e fatos como insumos para comparar as situações } \\
\text { anterior e posterior à implementação de qualquer novo processo a ser implementado; } \\
\text { - novo processo planejado para usuário do processo, entendendo suas necessidades e } \\
\text { convidando-o a participar das decisões, evitando-se a criação de resistências nas áreas; } \\
\text { - para cada macro-processo da cadeia de valor existe um único dono de processo, } \\
\text { geralmente gestor da área que esteja presente no dia a dia de sua atuação; } \\
\text { - dono do processo e seu papel ainda não são divulgados maciçamente para todos os } \\
\text { níveis da empresa, apenas alta hierarquia (presidência, vice-presidência e diretoria); } \\
\text { - em caso de novo processo consolidado, realiza-se transferência de dono de processo da } \\
\text { área de Qualidade e Processos para área responsável por aquele processo, transferindo } \\
\text { também conhecimento do negócio, contatos, etc.; }\end{array}$ \\
\hline $\begin{array}{l}\text { (3.4) Implementação } \\
\text { de melhoria de } \\
\text { processos }\end{array}$ & $\begin{array}{l}\text { - utiliza tanto apanhado de conceitos e técnicas acadêmicas quanto de boas práticas de } \\
\text { mercado, não se fixando metodologia específica; } \\
\text { - foco e disciplina em obter soluções práticas, de simples implementação, com ganhos } \\
\text { rápidos, embasados por estudos históricos da realidade; } \\
\text { - não há etapas formalmente nominadas, porém podemos resumir em: identificação do } \\
\text { problema, estabelecimento de plano de ação, desdobramento de resultados e } \\
\text { formalização do processo }\end{array}$ \\
\hline
\end{tabular}




\begin{tabular}{|c|c|}
\hline $\begin{array}{c}\text { Conceitos da } \\
\text { Literatura }\end{array}$ & Análise do Caso B \\
\hline$\checkmark$ Dificuldades & $\begin{array}{l}\text { - humanas: eventuais resistência de colaboradores em aceitar mudanças; para minimizar } \\
\text { efeitos, realização de política de bastidores e participação de diretores na construção de } \\
\text { novo processo (captar comentários construtivos, sentir-se parte do processo); } \\
\text { - de tempo e recursos financeiros: falta de tempo para implantar a solução ótima; } \\
\text { reaproveitamento de recursos disponíveis para se atingir os bons resultados possíveis; } \\
\text { - técnica, de tecnologia e metodologia: alta demanda para área de TI sendo sua prioridade } \\
\text { diferente de Qualidade e Processos; estabelecimento de parcerias (ex.: agência de } \\
\text { viagens) para implantar sistemas e minimizar efeitos; } \\
\text { - política e gestão: poucas vezes há desconforto com novo ambiente de trabalho } \\
\text { suplantado por treinamentos e atuação do gestor; }\end{array}$ \\
\hline $\begin{array}{l}\checkmark \text { Fatores críticos } \\
\text { de sucesso }\end{array}$ & $\begin{array}{l}\text { - apoio da alta gestão: Presidência é principal patrocinadora da área de Qualidade e } \\
\text { - } \text { arocessos atuar como facilitadora para demais áreas buscarem melhoria dos processos; } \\
\text { necessariamente alinhado a objetivos estratégicos; } \\
\text { - avaliação de desempenho e efeito de demonstração: preocupação em mostrar resultados } \\
\text { de forma relativamente rápida balanceando o quão detalhista ser e o quanto de resultado } \\
\text { se pretende atingir; realização de projeto piloto permite ajustar pontos inadequados da } \\
\text { solução proposta e utilizar os resultados obtidos como vitrine do plano de ação em } \\
\text { escala global na empresa; } \\
\text { - presença de liderança: área de Qualidade e Processos conduzindo projetos de melhoria } \\
\text { de processos com autonomia para convidar envolvidos a elaborar novo processo; } \\
\text { - uso efetivo de tecnologia de informação: processos mapeados registrados em sistema; } \\
\text { desenvolvimento de sistema de apoio para melhorar processo (exemplo do processo de } \\
\text { gestão de viagens corporativas); } \\
\text { - comunicação e transferência de conhecimento: comunicação eficiente sobre novo } \\
\text { processo através de correio eletrônico, portal e conversa de bastidores, auxiliando } \\
\text { aceitação e destacando papel dos gestores para orientar funcionários; transição de dono } \\
\text { do processo, com foco em conquistar comprometimento do novo gestor; } \\
\text { - rigor na implementação de melhorias: não segue necessariamente rigor metodológico } \\
\text { fixo, mas planeja e realiza ações de maneira estruturada e adaptada à necessidade; } \\
\text { - gestão da mudança em recursos humanos: Qualidade e Processos como facilitadora e } \\
\text { isenta, foco nas melhorias para a empresa como um todo, trabalho de bastidores junto } \\
\text { aos envolvidos, diminuindo resistências ao novo processo; } \\
\text { - seleção criteriosa de colaboradores: participação de envolvidos para propor novo } \\
\text { processo; definição de dono do processo que esteja presente no dia a dia de sua atuação; } \\
\text { - concorrência de mercado: varejo exige resultados rápidos sem se desviar das atividades } \\
\text { previamente estabelecidas mesmo frente a problemas vivenciados no dia a dia das lojas. }\end{array}$ \\
\hline (3.5) Indicadores & $\begin{array}{l}\text { - atribuição de indicadores que garantam criação de histórico de dados de forma que dono } \\
\text { do processo possa realizar supervisão e acompanhamento de resultados conforme metas } \\
\text { planejadas; } \\
\text { - indicadores não são formalmente alinhados com a perspectiva estratégica da empresa ou } \\
\text { ainda relacionados ao cliente final; } \\
\text { - indicadores avaliam desempenho do processo em si, de forma a permitir, analisar } \\
\text { potencial de melhoria contínua daquele processo. }\end{array}$ \\
\hline
\end{tabular}




\subsection{Empresa C}

\subsubsection{Estrutura e Funcionamento}

A empresa $\mathrm{C}$ é uma multinacional atuando no Brasil como uma das líderes de varejo de supermercados. A partir de 2008, incluiu em sua estratégia desenvolver a cultura de processos, resultando na criação da área de Processos, atrelada à Diretoria Executiva Financeira, dentro da diretoria de TI.

A área de Processos, dedicada exclusivamente a realizar a abordagem estruturada de processos, é responsável pela documentação, mapeamento e implantação de melhorias de processos de todas as áreas operacionais (lojas) e matriz, desenvolvendo ainda de forma inicial a gestão e acompanhamento de indicadores de nível de serviço atrelados a processos.

Para formalização de fluxos, a empresa C utiliza a ferramenta MS Visio para registrar as atividades, suportada por demais componentes do MS Office (PowerPoint, Excel e Word)

Em geral, os processos possuem gestores definidos, são publicados no portal da empresa no formato de leitura disponibilizado pela Adobe Acrobat e comunicados aos envolvidos por correio eletrônico. Vale ressaltar que todos colaboradores possuem acesso ao portal, inclusive aqueles de loja.

\subsubsection{Metodologia para Melhoria de Processos}

A empresa C vivenciou em 2004 uma reestruturação baseada em processos ("reengenharia de processos"), porém muito mais ligada às pessoas que ocupavam os cargos do que aos processos em si da empresa. Essa iniciativa trouxe em sua essência "melhorar a vida na empresa", no entanto acabou caindo no esquecimento ao longo do tempo.

Por outro lado, a empresa $\mathrm{C}$ busca atualmente a melhoria contínua de processos, mesmo sem ter aplicado formalmente iniciativas estruturadas do tipo Lean Production, Kaizen ou Six Sigma. Para isso, foi contratada em 2008 consultoria especializada para capacitar a equipe fixa da área de Processos e implantar como principal ferramenta de melhoria de processo o 
ciclo PDCA - Plan, Do, Check, Act - proposto por Deming na literatura clássica de Gestão da Qualidade. A figura a seguir representa estas etapas:

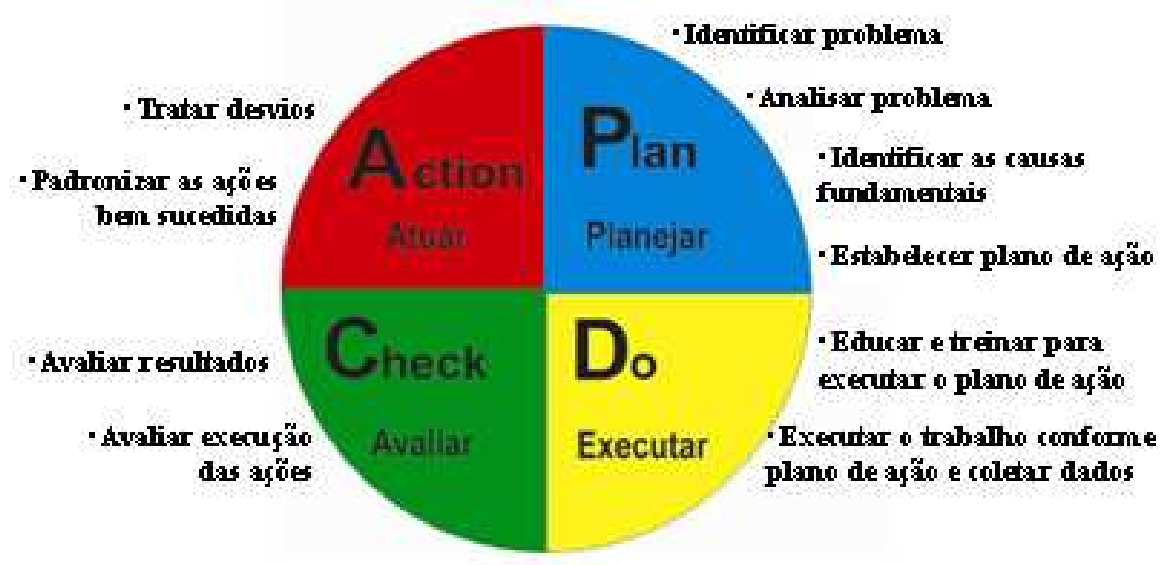

Figura 10 - As quatro etapas da metodologia PDCA

(Fonte : documentos da empresa C)

\subsubsection{Atuação para Abordagem de Processos}

A área de Processos da empresa C não possui definição formal para processo, mas entende de forma genérica o termo processo como encadeamento de atividades com início e fim. Em geral, as áreas da empresa possuem uma visão vertical dos processos focada em seus próprios objetivos. Isto se deve ao fato de que a cultura de processos é relativamente recente e o universo de varejo exige resultados imediatos. No entanto, pouco a pouco, conforme casos de sucesso de implementação de melhorias, a abordagem de processos está sendo assimilada pelas áreas juntamente com a conscientização da necessidade de planejamento com a finalidade de obter resultados importantes e direcionados.

A área de Processos atua de forma clara e definida na melhoria de processos administrativos e de suporte da empresa, permitindo às demais áreas atuar de maneira focada em sua operação principal. Conforme solicitação de áreas demandantes, a equipe de Processos atua em projetos de melhoria de processos com problemas em evidência, mas não necessariamente como desdobramento de objetivos pré-estabelecidos da empresa. Desta forma, a equipe da área de Processos busca satisfação de clientes internos da empresa, mas não necessariamente atua focado em melhorias para o cliente final. 
Por outro lado, destaca-se a figura do Presidente da empresa que incorpora constantemente em seu discurso, em reuniões e apresentações, a importância de "ter disciplina na execução de atividades". Nesse sentido, há valorização em trabalhar a utilização de processos na melhoria de resultados da empresa, o que não significa atuar conforme planejamento estratégico da empresa.

Em seu método de trabalho, para mapear atividades e estabelecer um plano de ação, a equipe de Processos procura entender minuciosamente quem é o público alvo a ser atingido e qual o grau de confidencialidade das informações em questão. Dentre as possibilidades a serem realizadas, pode-se destacar:

- fluxos: apresenta o desenho de funcionamento do processo e folha de rosto com nome dos entrevistados, aprovadores, sumário, objetivo, aplicação, definições e legenda. Utilizado como material de estudo e conscientização, apesar de destinar-se principalmente para cargos hierárquicos não operacionais, quando enviado a cargos operacionais, o documento é acompanhado de texto explicativo.

- procedimentos: apresenta um conjunto de orientações, redigidas conforme público alvo, para realizar com sucesso as atividades de um processo. Também utilizado como material de estudo e conscientização, destina-se para cargos operacionais e não operacionais.

- políticas: normas da empresa que devem ser impreterivelmente cumpridas. Utilizado quando existe necessidade de estabelecer regras a serem cumpridas por toda empresa conforme diretrizes da alta administração (ex.: código de ética, normas de telefonia, despesas com viagens, etc).

- projetos: conjunto de ações concentrando esforços temporários para criar um produto, serviço ou resultado exclusivo. Utilizado para empreendimentos maiores quando a solução é mais complexa de ser implantada.

Os procedimentos sempre são escritos a partir de fluxo previamente desenhado, enquanto que o fluxo, por sua vez, pode ou não ter procedimento escrito em $M S$ Word, dependendo de cada caso e da decisão conjunta da área de Processos e área cliente.

O mapeamento de processos é realizado junto aos executores das atividades, através de entrevista in loco, sem metodologia específica para realizar a entrevista. Em geral realiza-se reunião, entendem-se as etapas e anotam-se informações coletadas junto ao executor. São feitas tantas entrevistas quanto forem necessárias até validação formal dos executores e 
gestores. Esta validação pode ser via email ou assinatura enquanto que o arquivamento das assinaturas ou email não é necessariamente uma exigência da área. $\mathrm{Na}$ verdade, o objetivo em si é simplesmente ter o comprometimento dos envolvidos.

A área de Processos é neutra na empresa, tendo bom relacionamento com áreas da matriz e loja. Desta forma, os departamentos têm espírito colaborativo quando são solicitados a participar da melhoria de processo em que a área de Processos esteja atuando.

Para isso, a as melhorias de processos são propostas de forma conjunta tanto pelo executor do processo (que conhece o dia a dia de trabalho) quanto pela equipe de Processos apresentando um olhar externo às atividades do processo. Neste último caso, o especialista atua de duas formas: conhecendo o processo para aprender com o usuário como executar as atividades e utilizando senso crítico de questionamento para melhorias e ponto de controle, a partir da base adquirida em treinamento de processos.

Por sua vez, o profissional de Processos tem papel fundamental de intermediar as áreas, procurando convencer os envolvidos sobre como implementar melhorias, baseado em argumentos práticos e reais focados em resultados.

No entanto, existem dificuldades no canal de comunicação entre loja e matriz dado que os colaboradores de loja ao executar as orientações não transmitem frequentemente dificuldades e sugestões de melhoria, ora pela ausência de proatividade ora porque desconhecem como fazê-lo.

Dentre as principais dificuldades encontradas, pode-se afirmar que a realização de treinamento no novo processo é o maior desafio para empresa C. Considerando que esta empresa de varejo de grande porte possui lojas em todo Brasil, o nivelamento de conhecimento deve considerar regionalidades, alto índice de rotatividade (turnover) e disponibilidade dos colaboradores de chão de loja para interromper suas atividades para receberem capacitação. Para estes colaboradores é evidente a importância de executar o processo de maneira correta, entendendo de forma holística sua participação e impacto de suas atividades sobre as demais.

Além disso, fica evidente que os processos executados em loja não são feitos de maneira incorreta por livre arbítrio dos colaboradores, mas geralmente porque desconhecem a forma correta de ser executado. Isto ressalta uma das dificuldades de se implantar melhorias de processos em empresas de varejo: a perda de informações ao longo do tempo. Apesar de haver difusão de conhecimento padronizada (portal corporativo, reunião em loja, etc.), possíveis explicações para aquele fato podem ser a alta rotatividade de colaboradores de loja, grande quantidade de lojas e questões culturais conforme região do país onde a loja esteja 
presente. Portanto, existe a necessidade de monitorar periodicamente o resultado das atividades para verificar se os colaboradores cumprem as tarefas conforme foram capacitados.

Nesse sentido, para garantir o cumprimento das atividades de forma adequada, a empresa $\mathrm{C}$ atua em duas frentes: atribuição de dono do processo para monitorar a evolução do processo e definição de indicadores, chamados de pontos de controle.

O dono do processo está ciente de suas responsabilidades sendo claramente apresentado como responsável pelo processo aos envolvidos. Para a empresa, o dono do processo desempenha importante papel na alteração e na revisão de procedimento, inclusão de novas atividades e acompanhamento do processo como um todo. Ele é ainda responsável por tomar providências e monitorar, direta ou indiretamente, o cumprimento de instruções do procedimento. Cabe também ao dono do processo definir as regras, levando em consideração a participação de todos. Para isso, realizam-se reuniões diversas, envolvendo-se áreas de interesse. Conseqüentemente, geram-se laços de parceria entre as áreas, eliminam-se barreiras de resistência na implantação do plano de ação e aumenta o sentimento de participação conjunta nas definições do processo, atingindo-se melhores resultados.

A definição de indicadores, chamados de pontos de controle, tem o objetivo principal de monitorar periodicamente o resultado das atividades para verificar se os colaboradores cumprem as tarefas conforme foram capacitados. No entanto, trata-se puramente de indicadores dos resultados obtidos com a melhoria do processo e não necessariamente indicadores de nível de serviço ou ainda de alinhamento com cliente final em uma perspectiva estratégica da empresa. Portanto, a escolha de indicador é muito mais útil para que o "dono do processo" possa monitorar, por exemplo através de sistema, as atividades realizadas do que a empresa tenha um parâmetro perfeitamente estabelecido alinhado com sua estratégia.

\subsubsection{Exemplo de Projeto de Melhoria de Processos}

A partir da pesquisa de campo, o autor pode coletar informações a respeito de dois projetos (quadro 13) de melhoria de processos na empresa C: arquivo morto (quadro 14) e inventário em loja (quadro 15). 
Quadro 13 - Exemplos de projetos de melhoria de processos na empresa C

\begin{tabular}{|c|c|c|}
\hline $\begin{array}{c}\text { Projeto de } \\
\text { Melhoria }\end{array}$ & Definição ${ }^{3}$ & Histórico \\
\hline $\begin{array}{c}\text { Inventário em } \\
\text { Loja }\end{array}$ & $\begin{array}{l}\text { O processo de arquivo morto } \\
\text { compreende as etapas desde separação e } \\
\text { organização de documentos fiscais } \\
\text { (notas, bobinas, livros, etc.) feita pelos } \\
\text { colaboradores do setor administrativo } \\
\text { das lojas, acondicionamento em caixas, } \\
\text { identificação com etiquetas e envio dos } \\
\text { mesmos para prestadora de serviço, até } \\
\text { coleta, conferência, armazenagem, } \\
\text { atendimento a solicitações de reenvio de } \\
\text { documentos em caso de eventuais visitas } \\
\text { fiscais. } \\
\text { O processo de inventário em lojas } \\
\text { compreende a definição de cronograma e } \\
\text { preparação de loja, passando pela } \\
\text { inspeção de loja e contagem de produtos, } \\
\text { até a elaboração de relatório e ajustes de } \\
\text { estoque. }\end{array}$ & $\begin{array}{l}\text { A partir de 2004, optou-se por terceirizar serviços de } \\
\text { arquivo morto da matriz, lojas e centrais de } \\
\text { distribuição (alimentos e não alimentos) } \\
\text { comunicando os envolvidos sobre nova forma de } \\
\text { trabalho (acondicionamento, frequiência de envio, } \\
\text { etc.). Estas informações perderam-se ao longo do } \\
\text { tempo, provavelmente devido rotatividade de } \\
\text { colaboradores, dificuldade de organização (envio, } \\
\text { acondicionamento e busca de documentos) e falta de } \\
\text { comprometimento dos envolvidos (ex.: loja mantinha } \\
\text { arquivo morto na própria loja), o que em longo prazo } \\
\text { trouxe dificuldades para funcionamento do processo. } \\
\text { Durante ano de } 2008 \text {, área de Processos realizou } \\
\text { série de mapeamentos e melhorias de processos } \\
\text { ligados à área de Contabilidade. Ao final daquele } \\
\text { ano, constatou-se necessidade de compreender } \\
\text { atividades envolvidas no inventário de estoque em } \\
\text { lojas, dada proporção de valores envolvidos podendo } \\
\text { gerar discrepâncias de resultado contábil. } \\
\text { O inventário oficial de lojas é realizado } \\
\text { periodicamente por prestadora de serviço } \\
\text { encarregada de contar produtos presentes na área de } \\
\text { venda assim como no estoque de loja específica e } \\
\text { elaborar relatório com valores apurados. No entanto, } \\
\text { fisicamente presente em lugares diferentes. } \\
\text { dos produtos, colaborando na organização da área de } \\
\text { venda e depósito, agrupando itens similares e }\end{array}$ \\
\hline
\end{tabular}

Fonte: Elaborado pelo autor

\subsubsection{Arquivo Morto}

Para aperfeiçoar o processo, a área de Processos foi acionada pela área Tributária com objetivo de reduzir despesas de eventuais multas e autuações fiscais assim como melhorar a

\footnotetext{
${ }^{3}$ Conforme já mencionado no quadro 4 do item 4.2
} 
organização para o envio e reenvio de documentos para empresa prestadora de serviço. A atuação da área de Processos ocorreu de janeiro a setembro de 2009, englobando levantamento de causas, mapeamento de processo, proposição e implementação de melhorias.

O desenho a seguir apresenta as etapas do processo de Arquivo Morto:

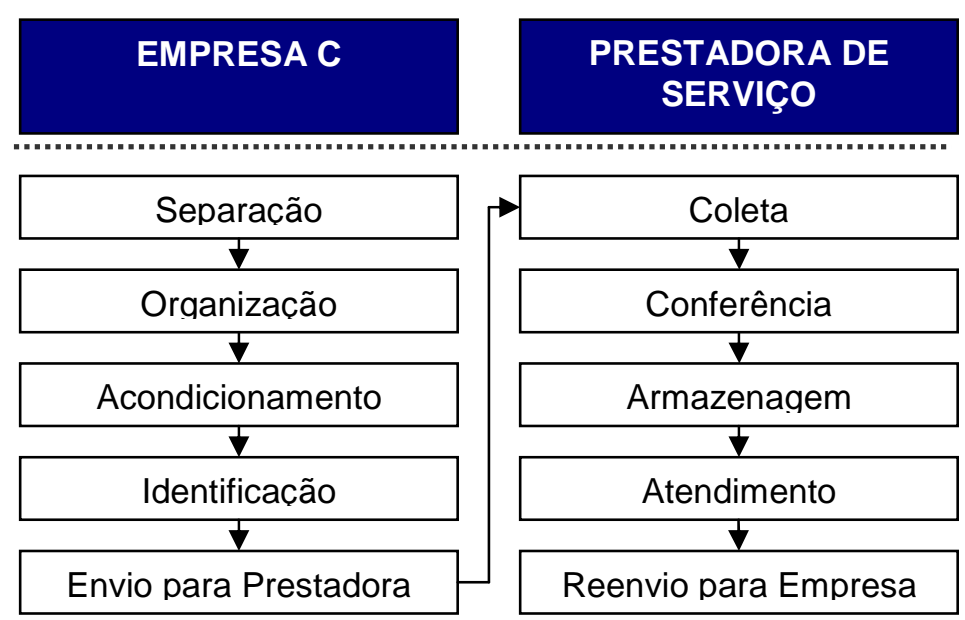

Figura 11 - As etapas do processo "Arquivo morto" (Fonte : elaborado pelo autor)

O especialista de Processos designado para atender demanda teve a responsabilidade de planejar as etapas para melhoria do processo. Para isso, foram realizadas reuniões individuais com os envolvidos no processo: área Tributária, loja e empresa prestadora de serviço.

\section{- Planejar (Plan)}

\section{$\rightarrow$ Identificar Problema}

A partir de entrevistas com diretoria da área Tributária, obteve-se panorama geral do processo, identificando e analisando os problemas existentes para listar as principais possíveis causas fundamentais. A partir daí, foi elaborado um fluxograma geral do processo, validado pelo próprio demandante, sobre como deveria funcionar o processo de Arquivo Morto.

\section{$\rightarrow$ Analisar Problema}

Em seguida, foram realizadas entrevistas junto a colaboradores de loja participantes enquanto executores do processo e da empresa prestadora de serviço procurando entender como na prática aconteciam as atividades do processo, e quais os principais problemas e dificuldades em sua operação. Ficou constatado desta forma que, eventualmente, a loja desconhecia o processo concebido pela matriz ou o executava de maneira incorreta (Ex.: frequência de envio inadequada, diferentes padrões de acondicionamento e etiquetagem, não 
utilização dos serviços de consulta e solicitações via internet propostos pela empresa prestadora de serviço, etc.).

\section{$\rightarrow$ Identificar as Causas Fundamentais}

Estas reuniões colocaram em evidência a visão limitada que cada um dos envolvidos tinha sobre o processo, sem conhecê-lo de forma holística. As partes tinham foco de executar pura e simplesmente suas próprias atividades, não necessariamente da melhor forma possível, o que poderia gerar impactos no desempenho das atividades seguintes. Isto pode ser ilustrado, por exemplo, pelo retrabalho da empresa prestadora de serviço na etapa de organização dos documentos, ocasionado por falhas no momento de separação e acondicionamento dos documentos em caixas realizado pelas lojas.

Foram evidenciados problemas na identificação e etiquetagem de caixas, dificultando a rastreabilidade de documentos além da falta de padronização na execução de atividades, gerando processos diferentes de funcionamento entre as lojas.

Finalmente, constatou-se dificuldades técnicas e operacionais no agendamento de horário para retirada de documentos da loja e desgaste de comunicação entre loja e prestadora de serviço no atendimento a solicitações de reenvio de documentos para atendimento à fiscalização.

\section{$\rightarrow$ Estabelecer Plano de Ação}

Uma vez identificados os problemas e suas causas, procurou-se coletar a partir de entrevistas e documentos desenvolvidos pelos próprios envolvidos, inclusive a área Tributária, informações sobre como deveria ser o funcionamento do processo ideal.

Baseado nas informações coletadas, estabeleceu-se como melhoria para o processo a necessidade de elaborar um procedimento, destinado principalmente aos colaboradores de loja e prestadora de serviço, determinando papéis e responsabilidades das atividades e estabelecendo pontos de controle do processo.

Para iniciar a redação deste procedimento, foi necessário levar em consideração quem eram os clientes do processo assim como demais envolvidos (não necessariamente usuários do procedimento), onde seria aplicado, qual nível técnico de conceitos e linguagem a ser utilizada. As soluções propostas neste procedimento tiveram origem no conhecimento da própria equipe de Processos e do demandante, além é claro das informações coletadas junto com entrevistados ao longo do mapeamento.

Assim, a equipe de Processos realizou reuniões de alinhamento semanais junto à área demandante, utilizando como ponto focal o gerente do Tributário, com objetivo de redigir e validar um procedimento explicativo do processo. Este material foi preparado com foco no 
usuário, destacando os benefícios de se realizar corretamente as atividades do processo, e convencê-lo a realizar as tarefas da forma proposta. Evitaram-se vocabulários técnicos e utilizaram-se expressões de linguagem mais adequadas ao usuário (colaborador de loja).

Em geral, o procedimento final apresenta ilustrações de documentos e formulários utilizados, instruções de como preenchê-los, as responsabilidade sobre os mesmos e explicações detalhadas de como executar o processo. Após aprovação do demandante, o procedimento foi testado por colaborador de Processos que não havia tido contato com o mesmo. O objetivo foi fazer releitura como usuário para verificar linguagem, clareza das informações ali contidas e testar na prática o procedimento. Em seguida, desenhou-se um fluxo detalhado do processo final, a partir do procedimento redigido, verificando inconsistências e falhas assim como pontos não previstos do processo, na tentativa de considerar todas as possibilidades do mesmo.

\section{- Executar (Do)}

\section{$\rightarrow$ Educar e Treinar para Executar Plano de ação}

Após a etapa de planejamento, surgiu a necessidade de definir os responsáveis por colocar em prática o procedimento. Para isso, realizou-se um trabalho de conscientização da importância do processo junto às hierarquias das áreas, envolvendo também áreas da matriz diretamente ligadas à operação da loja. Estas áreas da matriz possuem colaboradores que trabalham em loja, mas não respondem hierarquicamente para o gerente ou diretor da mesma. A atuação e comprometimento dos colaboradores destas áreas foram fundamentais para transmitir, acompanhar e garantir, no dia a dia da loja, a execução das atividades descritas no procedimento.

Uma vez estabelecido o comprometimento das áreas, realizou-se a divulgação formal do procedimento e início previsto de execução, através de comunicado via correio eletrônico destacando o apoio empenhado pelos diretores envolvidos. Informou-se também, neste caso, o gerente Tributário como responsável por monitorar eventuais alterações e comunicar a área de Processos sobre atualizações do procedimento. Esta área, por sua vez, permanece responsável pela metodologia, animação de debates, apoio e execução da elaboração do procedimento.

\section{$\rightarrow$ Executar Trabalho Conforme Plano de ação e Coletar Dados}

Para os colaboradores de loja, a hierarquia máxima é o gerente ou diretor de loja, portanto, toda orientação da matriz deve ser enfatizada por ele para que seja cumprida. Para garantir a realização do plano de ação, atribuiu-se a responsabilidades de execução do 
processo ao gerente ou diretor de loja, cabendo a ele designar um colaborador da área administrativa para executar as atividades conforme descritas no procedimento.

O cumprimento das tarefas citadas no procedimento teve como objetivo trazer as seguintes melhorias: (i) implantação de cronograma fixo de coleta de documentos eliminando as dificuldades de conciliar o agendamento via correio eletrônico e telefone com a operação do dia a dia da loja; (ii) explicação detalhada de acondicionamento (tipo de caixa, segregação e identificação de conteúdo); (iii) conferência dos documentos acondicionados nas caixas a partir de lista de verificação extraída de sistema do portal interno da empresa disponibilizado pela área tributária; (iv) criação de pontos de controles para garantir expedição, retorno e tratamento de inconsistências de documentos (protocolo de emissão, devolução e divergência de documentos) assim como confidencialidade de acesso a documentos (ex.: diretor de loja recebe aviso via correio eletrônico quando colaborador solicita documento para prestadora de serviço); (v) agilidade no reenvio de documentos com solicitação via website a fim de evitar autuações fiscais.

\section{- Avaliar (Check)}

\section{$\rightarrow$ Avaliar Execução das Ações e Resultados}

Ao realizar acompanhamento de resultados da implantação do procedimento, constatouse diminuição de custos, maior agilidade no (re)envio de documentos, melhor organização na execução das atividades, e amenização na relação entre prestadora de serviço e loja.

Neste caso foram implantados indicadores dos resultados obtidos com a melhoria do processo e não necessariamente indicadores de nível de serviço. A partir do alinhamento de expectativas de resultados entre a área de Processos e a área demandante, foi possível comparar, em relação ao ano anterior, indicadores internos de nível macro que possibilitaram constatar: (i) redução de custos com autuações fiscais; (ii) redução de autuações fiscais; (iii) redução de custo com organização feita pela prestadora de serviço.

\section{- Atuar (Action)}

\section{$\rightarrow$ Padronizar Ações Bem Sucedidas e Tratar Desvios}

A área Tributária foi designada para acompanhar o bom funcionamento do processo e detectar no longo prazo eventuais desvios em sua execução. Neste caso, a área de Processos poderá ser acionada para verificar as ações realizadas e intermediar na resolução destes problemas. Além disso, um colaborador da área Tributária foi especialmente designado para esclarecer dúvidas das lojas na execução das atividades descritas no procedimento. 
Quadro 14 - Exemplo de melhoria de processo de arquivo morto

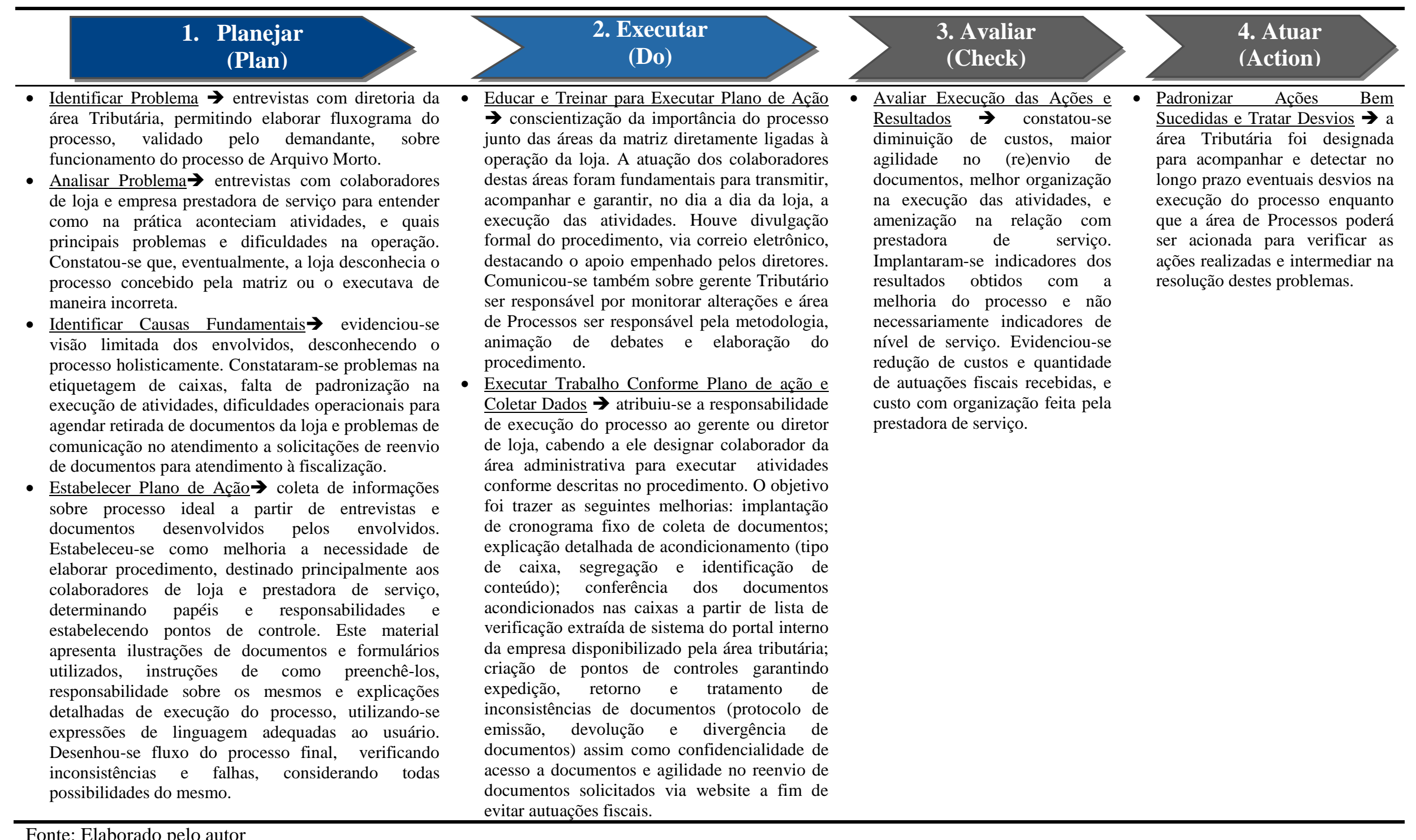

\footnotetext{
Fonte: Elaborado pelo autor
} 


\subsubsection{Inventário em Loja}

A área de Processos passou a atuar ativamente a partir de fevereiro 2009 até agosto daquele mesmo ano como facilitadora para formalizar e padronizar o processo de realização de inventário, estabelecendo-se regras de como realizar cada uma das etapas e determinandose papéis e responsabilidades da loja e da empresa prestadora de serviço. Além disso, entendeu-se como necessário, determinar freqüência de inventários a serem realizados de acordo com tipo e capacidade da loja.

O desenho a seguir apresenta as etapas deste processo:

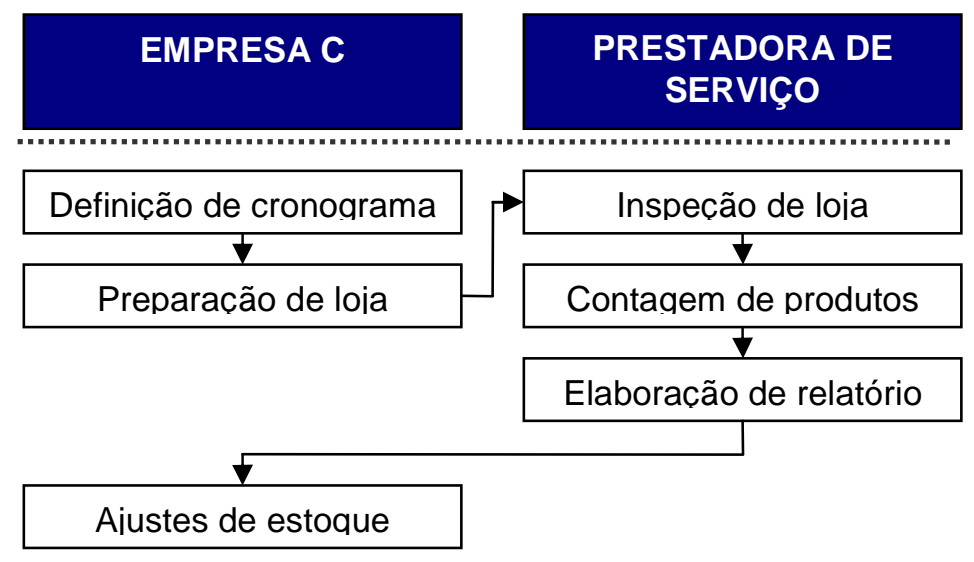

Figura 12 - As etapas do processo "Inventário em loja"

(Fonte : elaborado pelo autor)

- Definição de cronograma: as lojas possuem um cronograma de datas fixo ao longo do ano para realização de inventário;

- Preparação de loja: colaboradores de loja organizam depósito e área de venda para facilitar a contagem de produtos;

- Inspeção de loja: empresa prestadora de serviço averigua as condições de preparação da loja para realização de inventário. Caso a arrumação não esteja de acordo, empresa prestadora de serviço realiza a organização cobrando taxa suplementar pelo trabalho;

- Contagem: empresa prestadora de serviço realiza a contagem de produtos da área de venda e depósito de loja;

- Elaboração de relatório: empresa prestadora de serviço elabora relatório, a ser enviado para empresa $\mathrm{C}$, com dados de estoque e histórico de realização da contagem; 
- Ajustes de estoque: entrada (acerto) de diferenças de estoque no sistema da empresa.

Para aplicar ao caso a metodologia utilizada pela empresa $\mathrm{C}$, foi designado um especialista de Processos com a função de estruturar as etapas para melhoria do processo. Primeiramente, decidiu-se formar um comitê com representantes das áreas de Contabilidade, Processos, Prevenção de Perdas e Operações de Loja realizando reuniões periódicas para identificação do problema e suas principais causas.

\section{- Planejar (Plan)}

\section{$\rightarrow$ Identificar problema}

O problema com inventário de loja tornou-se evidente a partir das freqüentes retratações (ajustes) de estoque feitas pela loja e comunicadas à Contabilidade. Isto impactava diretamente em retrabalho para a área uma vez que utilizava dados de estoque incorretos para realização de cálculos contábeis.

Com a realização das reuniões do comitê, identificou-se como problema a contagem equivocada feita no inventário rotativo (feita pelos próprios colaboradores de loja) e a discrepância de estoque em relação ao sistema após realização do inventário oficial (feita pela empresa prestadora de serviço).

\section{$\rightarrow$ Analisar problema}

Para analisar o problema mais afundo, a área de Processos percebeu a necessidade de realizar reuniões de entendimento com os executores do processo, dentre eles a empresa prestadora de serviço e os próprios colaboradores de chão de loja.

\section{$\rightarrow$ Identificar as Causas Fundamentais}

Uma vez estabelecidas as macro etapas do processo de inventário, a partir das reuniões realizadas, definiu-se a contagem como o processo crítico de inventário. Ficaram constatadas como causas fundamentais do problema a contagem do inventário (ex.: falta de atenção na quantidade de itens por caixa, forma de cada colaborador contar era diferente, etc.) e a preparação e organização dos itens do depósito e da área de venda da loja.Verificou-se, portanto, a necessidade de padronizar a organização dos itens e o modo de como fazer detalhadamente a contagem de produtos.

\section{$\rightarrow$ Estabelecer Plano de Ação}

Com a definição do problema e suas causas evidentes para os envolvidos, a equipe de Processos, juntamente com as demais áreas, optou como plano de ação criar um procedimento. Vale ressaltar que a escolha por este documento levou em consideração o 
público alvo a ser atingido (colaboradores de loja) e o grau de confidencialidade das informações em questão.

O procedimento teve como objetivo principal descrever as principais etapas do processo de inventário como um todo, desde a definição do cronograma, preparação da loja e contagem até a retratação de estoque no sistema e envio de relatórios.

A definição de regras para cada uma das etapas deveria considerar quem eram as áreas afetadas pela realização do inventário. Portanto, atribuiu-se um dono do processo, no caso diretor de Contabilidade, principal área responsável pelo produto do processo, com a responsabilidade de envolver a área de Operações de loja e empresa prestadora de serviço nas discussões sobre o assunto para definir regras para cada etapa.

Desta forma, o estabelecimento de regras ocorreu em uma série de reuniões, com a participação da área de Processos atuando como facilitadora entre as demais. Ao final, o especialista daquela área elaborou um macro fluxo com as principais definições e etapas.

A partir daí, o especialista de Processos reuniu-se periodicamente com o diretor e colaboradores da Contabilidade, para redigir o procedimento contendo boas práticas, regras, pontos de controle e indicadores baseado nas informações coletadas em conversas com as outras áreas, além das necessidades, experiências e documentos anteriores (desenhos, apresentações, correio eletrônico, etc.) da área de Contabilidade.

Dentre algumas resoluções adotadas no procedimento, podemos destacar como exemplo: (i) a loja não tem permissão de receber mercadoria do Centro de Distribuição (CD) na véspera, durante e um dia após a realização de inventário. Portanto, a loja deve ser abastecida com antecedência; (ii) definição de cronograma anual por loja para realização de inventário; (iii) padronização na forma de contar produtos, começando pela área de venda e posteriormente o depósito, tendo um colaborador responsável por controlar o fluxo de entrada e saída do depósito; (iv) estabelecimento de pontos de controle padrão para todas lojas de como fazer inventário (recebimento de mercadorias, ordem de realização de inventário, etc.).

Após a validação do procedimento com o dono do processo, o documento foi exposto às demais áreas envolvidas sofrendo alguns "ajustes finos" de prazos (ex.: a loja tem sete dias para arrumar estoque antes do inventário) e datas (ex.: após o inventário oficial, a loja tem até o segundo dia do mês para retratar estoque).

Desta forma, o procedimento foi validado por todos envolvidos estabelecendo padrão de processo de inventário para todos os formatos de loja. 


\section{- Executar (Do)}

\section{$\rightarrow$ Educar e Treinar para Executar Plano de Ação}

A elaboração de procedimento teve a preocupação de envolver e atender todas as áreas que participam e são afetadas pelo processo de inventário. Em seguida, o procedimento foi divulgado no portal da empresa $\mathrm{C}$, buscando obter o comprometimento de todos. O desafio foi replicar as informações ali descritas para garantir que os executores seguiriam as instruções de forma a não prejudicar a qualidade de dados levantados ao longo de um inventário.

Desta forma, a equipe de Prevenção de Perdas foi acionada como responsável pelo treinamento de todos colaboradores de loja do Brasil, dada sua proximidade de contato diário em chão de loja.

Foram realizadas capacitações em massa ao longo de dois meses, reunindo responsáveis de loja, líderes de seção e operadores de supermercado com objetivo de nivelar o conhecimento sobre como realizar inventário de loja, explicando os devidos pontos de controles criados.

Ao longo do treinamento, evidenciou-se a falta de padrão existente entre as lojas na forma de execução de inventário de loja. Para algumas delas, houve mudanças radicais na maneira de organizar o depósito, realizar contagem e envolvimento dos colaboradores, enquanto que para outras o treinamento teve o papel de reforçar atividades já realizadas normalmente. Em suma, a capacitação atingiu o objetivo de padronizar a execução de inventário em todas lojas do Brasil.

\section{$\rightarrow$ Executar Trabalho Conforme Plano de Ação e Coletar Dados}

A realização do inventário é um trabalho operacional que depende da atenção e concentração dos colaboradores envolvidos. O bom resultado pode ser atingido a partir das instruções do procedimento, mas não há garantia de que, mesmo com treinamentos, os colaboradores executarão as etapas do processo conforme regras definidas.

Portanto, existe a necessidade de criar mecanismos e indicadores para monitorar o desempenho das atividades deste processo. No caso estudado, a empresa C adotou os seguintes pontos de controle: (i) utilização de lista de checagem para conferir arrumação na etapa de inspeção de loja pré- contagem; (ii) quantidade de retratações (ajustes) de estoque mensais realizadas por loja, em caso de erro de contagem, conforme registro em sistema da empresa.

A lista de checagem preenchida pela empresa prestadora de serviço é enviada para Contabilidade com comentários e recomendações sobre a possibilidade ou não de realização de inventário. Caso a loja não esteja em condições de organização adequada (ex.: estoque 
sobrecarregado) ou por motivos sazonais (ex.: troca de coleção, teatralização de mercadorias, ação de marketing, etc.) o inventário pode ser adiado. Assim, consequentemente, criou-se um mecanismo de acompanhamento das principais dificuldades de preparação de loja e de formalização caso seja necessário adiamento de inventário.

Vale ressaltar que a escolha do indicador "quantidade de retratações de estoque mensais por loja" não foi ao acaso. A retratação de estoque impacta na execução das atividades da Contabilidade, aumentando retrabalhos e prejudicando o tempo de execução das tarefas. Assim, o monitoramento do processo passou a ser feito por esta área ("dona do processo") que nas atividades do dia a dia poderia acompanhar automaticamente, via sistema, as alterações de estoque realizadas. Com os dados obtidos, criou-se um ranking de lojas com maiores problemas e constataram-se quais lojas cometiam mais erros de contagem podendo assim entender junto delas os devidos motivos.

A Contabilidade, tendo seu diretor como dono do processo, teve a responsabilidade de cobrar devidas atitudes para evolução de resultados. Tratando-se de um processo, as melhorias são gradativas, e portanto, as lojas empenharam-se ao longo do tempo para organizar melhor o depósito e realizar inventário rotativo sem muitos erros. Com amadurecimento dos conceitos descritos no procedimento (ex.: melhoria da qualidade da preparação de estoque, realização correta de inventário rotativo, etc.) as lojas em geral, diminuíram a quantidade de 15 a 20 para apenas 3 a 5 retratações por mês por loja.

A atribuição de dono do processo e utilização de indicador para monitoramento foram de extrema importância para verificar melhorias. Apesar das retratações de estoque acontecerem em chão de loja, e portanto, diretamente ligado a área de Operações, na visão da empresa a área de Contabilidade teve de monitorar e acompanhar o indicador uma vez que ela é a "dona do processo" e tem maior facilidade de acesso para registro e obtenção de valores.

\section{- Avaliar (Check)}

\section{$\rightarrow$ Avaliar Execução das Ações e Resultados}

$\mathrm{A}$ empresa $\mathrm{C}$ designou à equipe de Prevenção de Perdas a responsabilidade de realizar "Diagnóstico de Trabalho Operacional (DTO)" para verificar na prática se colaboradores de loja estavam cumprindo corretamente trabalho proposto, conforme instruções do procedimento do processo de inventário. Neste diagnóstico concluiu-se que a contagem de produtos não estava sendo realizada da forma correta (ex.: não verificar se caixa estava aberta ou fechada, falta de atenção com quantidade de itens por caixa, etc.). Apesar do procedimento 
conter informações genéricas sobre modo de realizar contagem, estas instruções não eram claras para conscientizar colaboradores da importância deste processo operacional.

Decidiu-se, portanto, somente para processo crítico de contagem, elaborar "Procedimento Operacional Padrão (POP)" com explicação passo a passo de como fazer contagem. Este é um documento com figuras, fotos ilustrativas e explicações com linguagem didática de como executar cada uma das tarefas de contagem (ex.: verificar para todas as caixas a quantidade de itens, presença ou não de lacre, etc.). Além disso, definiu-se e comunicou-se claramente padrão de loja preparada para realizar inventário, ensinando-se aos colaboradores de loja forma de utilizar lista de checagem para conferir arrumação. Finalmente, aplicou-se novo treinamento para lojas, tendo como assunto o "POP" de contagem e comunicação da importância de sua execução.

\section{- Atuar (Action)}

\section{$\rightarrow$ Padronizar Ações Bem Sucedidas e Tratar Desvios}

Até a data de finalização desta pesquisa, o "POP" teve sucesso, ressaltando importância de realizar contagem com qualidade de dados e esclarecendo dúvidas operacionais dos colaboradores. A Prevenção de Perdas continua encarregada de verificar em loja execução das atividades enquanto Contabilidade monitora resultados do processo como um todo.

A empresa $\mathrm{C}$ periodicamente revisa os procedimentos publicados. No caso do procedimento de inventário, desenvolve-se para nova versão, ênfase nas ações bem sucedidas de organização dos depósitos na etapa de preparação e forma de realizar contagem de produtos descritas no "POP". Além disso, reforça o papel da Contabilidade como "dona do processo" para acionar os envolvidos em eventuais situações novas não descritas no procedimento existente. Para futuras capacitações de reciclagem de equipe, pretende-se também utilizar material de treinamento mais lúdico, didático e visual, adaptando linguagem para público alvo. 
Quadro 15 - Exemplo de melhoria de processo de inventário em loja

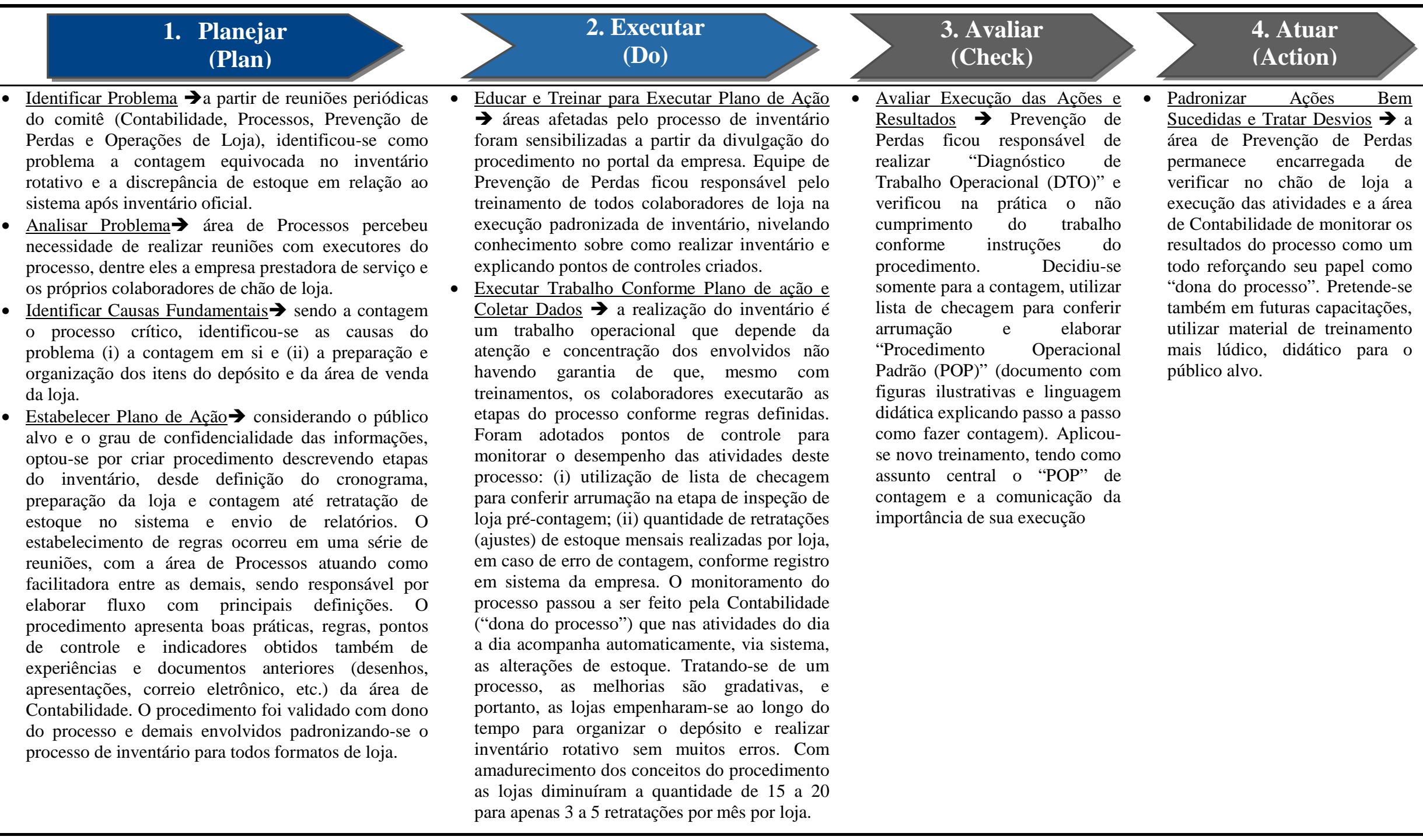

Fonte: Elaborado pelo autor 


\subsubsection{Análise do Caso C}

Assim como nos casos anteriores, o autor pode preparar para o caso $\mathrm{C}$ painel de dados (quadro 16) relacionando itens relevantes da literatura com as fontes de evidência, buscando destacar pontos para responder à pergunta de pesquisa.

Quadro 16 - Conceitos da literatura e análise do caso C

\begin{tabular}{|c|c|}
\hline $\begin{array}{c}\text { Conceitos da } \\
\text { Literatura }\end{array}$ & Análise do Caso C \\
\hline (3.1) Processos & $\begin{array}{l}\text { - não possui definição formal para processo, mas entende termo como encadeamento de } \\
\text { atividades com início e fim; } \\
\text { - cultura de processos é relativamente recente; } \\
\text { - melhoria de processos administrativos e de suporte da empresa; } \\
\text { - atuação em projetos de melhoria de processos conforme demanda das áreas, não } \\
\text { necessariamente como desdobramento de objetivos pré-estabelecidos da empresa; } \\
\text { - busca satisfação de clientes internos da empresa, mas não necessariamente atua focado } \\
\text { em melhorias para o cliente final; } \\
\text { - divulgação de processos via email e em intranet da empresa; }\end{array}$ \\
\hline $\begin{array}{l}\text { (3.2) Gestão por } \\
\text { processos }\end{array}$ & $\begin{array}{l}\text { - atuação da área de Processos de forma estruturada e disciplinada para cumprimento de } \\
\text { etapas da metodologia, valorizando principalmente planejamento antes da execução; } \\
\text { - conforme há sucesso de implementação de melhorias, há conscientização das áreas de } \\
\text { que para obter resultados concretos e direcionados é necessário planejamento; } \\
\text { - áreas da empresa possuem uma visão vertical dos processos focada em seus próprios } \\
\text { objetivos; }\end{array}$ \\
\hline $\begin{array}{l}\text { (3.3) Melhoria de } \\
\text { processos }\end{array}$ & $\begin{array}{l}\text { - vivenciou "reengenharia de processos", porém muito mais ligada às pessoas que } \\
\text { ocupavam os cargos do que aos processos em si da empresa; } \\
\text { - pratica melhoria contínua de processos, sem ter aplicado formalmente iniciativas } \\
\text { estruturadas do tipo Lean Production, Kaizen ou Six Sigma, somente ciclo PDCA; } \\
\text { - mapeamento de processo realizado junto aos executores das atividades, através de } \\
\text { entrevista in loco, sem metodologia específica para realizar a entrevista; } \\
\text { - validação formal via email ou assinatura (sem obrigatoriedade de arquivamento da } \\
\text { mesma) com objetivo de obter comprometimento dos envolvidos; } \\
\text { - mapeamento evidencia para envolvidos sua participação e impacto de suas atividades } \\
\text { sobre as demais; } \\
\text { - processos detalhados em fluxos, procedimentos e políticas, dependendo do projeto de } \\
\text { melhoria que área de Processos está atuando, público alvo a ser atingido e grau de } \\
\text { confidencialidade das informações em questão; } \\
\text { - dono do processo claramente apresentado como responsável pelo processo, atuando na } \\
\text { alteração e revisão de procedimento, inclusão de novas atividades, acompanhamento do } \\
\text { processo como um todo e envolvimento das áreas participantes; }\end{array}$ \\
\hline $\begin{array}{l}\text { (3.4) Implementação } \\
\text { de melhoria de } \\
\text { processos }\end{array}$ & $\begin{array}{l}\text { - utiliza metodologia específica do ciclo PDCA adaptada para realidade da empresa; } \\
\text { - foco no público alvo a ser atingido pelo novo processo; } \\
\text { - etapas: planejar (identificar problema, analisar problema, identificar causas } \\
\text { fundamentais, estabelecer plano de ação); executar (educar e treinar para executar plano } \\
\text { de ação, executar trabalho conforme plano de ação e coletar dados); avaliar (avaliar } \\
\text { execução de ações e avaliar resultados); atuar (padronizar ações bem sucedidas, tratar } \\
\text { desvios) }\end{array}$ \\
\hline
\end{tabular}




\begin{tabular}{|c|c|}
\hline $\begin{array}{c}\text { Conceitos da } \\
\text { Literatura }\end{array}$ & Análise do Caso C \\
\hline$\checkmark$ Dificuldades & $\begin{array}{l}\text { - humanas: resistência em aceitar novo processo evitada com trabalho prévio envolvendo } \\
\text { pessoas durante proposta de novo processo; } \\
\text { - de tempo e recursos financeiros: equipe enxuta, traz bons resultados, mas demanda é } \\
\text { maior do que a equipe pode atender, sendo necessários recursos financeiros para } \\
\text { contratar mais gente capacitada para atender demandas; } \\
\text { - técnica, de tecnologia e metodologia: dificuldades técnicas para realização de } \\
\text { treinamento no novo processo (lojas em todo Brasil, regionalidades, alto índice de } \\
\text { rotatividade e disponibilidade dos colaboradores de chão de loja); } \\
\text { - política e gestão: dificuldades no canal de comunicação entre loja e matriz; perda de } \\
\text { informações ao longo do tempo (alta rotatividade de colaboradores de loja, grande } \\
\text { quantidade de lojas e questões culturais conforme região do país onde a loja esteja } \\
\text { presente); dificuldade em garantir que executores sigam procedimento estabelecido; }\end{array}$ \\
\hline $\begin{array}{l}\checkmark \text { Fatores críticos } \\
\text { de sucesso }\end{array}$ & 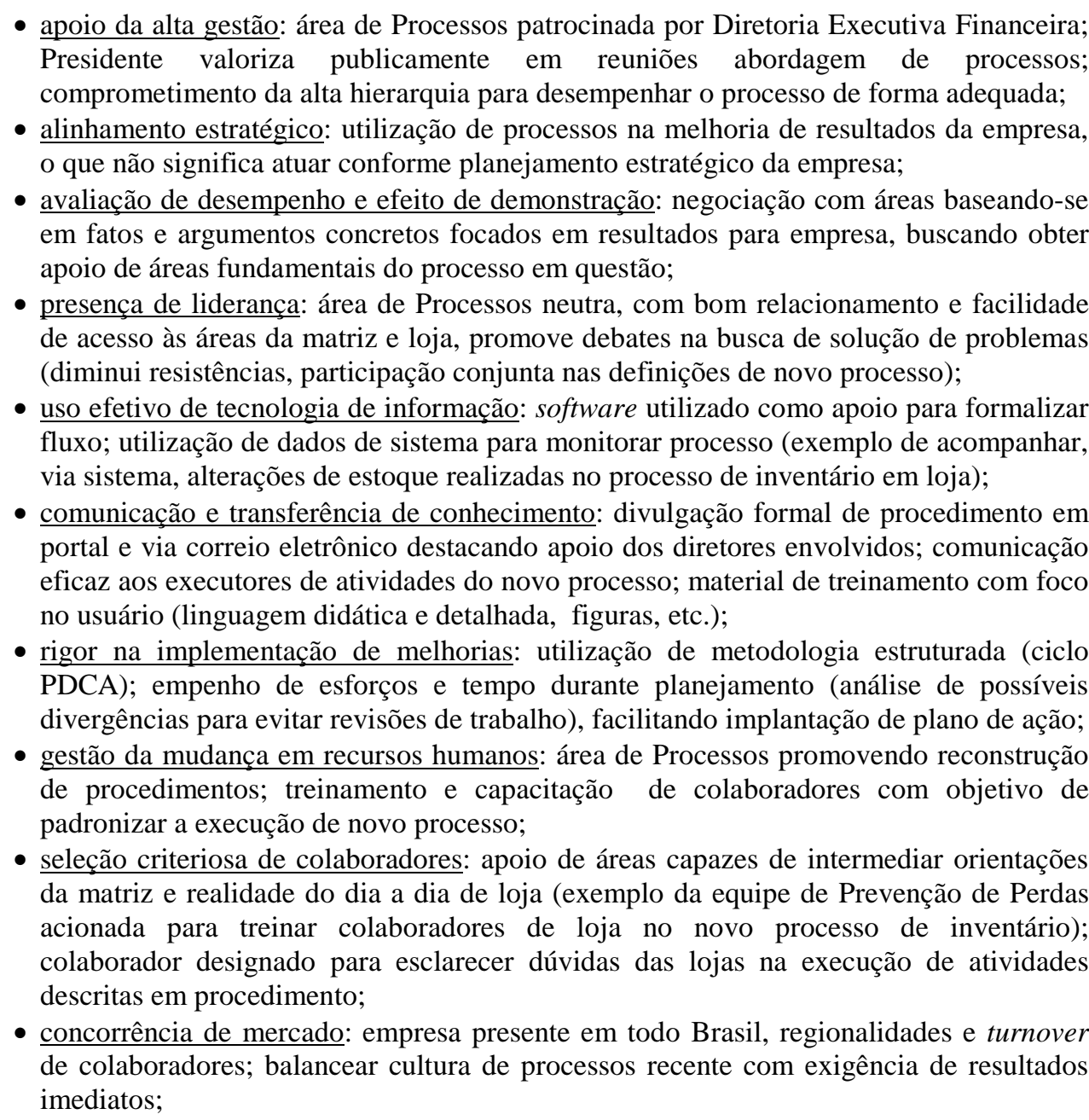 \\
\hline (3.5) Indicadores & $\begin{array}{l}\text { - definição de indicadores, chamados pontos de controle, para monitorar periodicamente } \\
\text { atividades realizadas e verificar se colaboradores cumprem tarefas conforme foram } \\
\text { capacitados; } \\
\text { - indicadores de resultados obtidos com a melhoria do processo e não necessariamente } \\
\text { indicadores de nível de serviço ou ainda de alinhamento com cliente final em uma } \\
\text { perspectiva estratégica da empresa. }\end{array}$ \\
\hline
\end{tabular}




\section{ANÁLISE CRUZADA DOS CASOS}

Os diferentes painéis (quadros 8, 12 e 16) elaborados para cada caso estudado, permite construir consolidado de informações (Apêndice B) a partir do qual é possível realizar análise cruzada dos casos relacionando variáveis de pesquisa, e verificar padrões e interpretações dos casos. O objetivo foi criar um resumo de evidências para embasar as conclusões, considerando análise de convergência e divergência do cruzamento de informações.

\section{- Processos}

De forma geral, as grandes empresas de varejo estudadas possuem cultura de processos recente e nível inicial de conceitos de processos aplicados conforme maturidade da empresa frente a conhecimentos de qualidade. Isto implica que elas podem ou não ter definição formal de processos, porém seu conceito é claro para área de Processos e diretoria a qual está atrelada. Por outro lado, estas empresas se esforçam para amadurecer o conceito de processos principalmente para as outras áreas. Nesse sentido, os processos são divulgados no portal da empresa ou via email para todos participantes dos projetos de melhoria de processos.

As áreas de Processos das empresas atuam de forma passiva na proposta de quais projetos de melhoria de processos serão trabalhados. A escolha de processos a serem melhorados acontece conforme interesse da área patrocinadora do projeto. A maior parte dos casos são processos administrativos e de suporte da empresa, não necessariamente relacionadas diretamente ao modelo de negócio da organização ou ainda ao cliente final. Além disso, esses projetos de melhoria podem ter conexão com objetivos "genéricos" (ex. redução de custos), mas não são desdobramento do planejamento estratégico da empresa.

\section{- Gestão por processos}

A área de Processos das empresas atua de forma coordenada, estruturada e disciplinada na melhoria de processos, valorizando planejamento antes da execução, sem perder foco no resultado final desejado. Conforme Oliveira (2006), são necessários planejamento, organização, direção e avaliação das atividades, minimizando-se conflitos interpessoais em prol de necessidades e expectativas de clientes externos e internos à empresa.

Por sua vez, as áreas corporativas possuem visão verticalizada, focada em seus próprios objetivos, executando atividades sem necessariamente conhecer a visão completa do processo. 
No entanto, após participarem de projetos de melhoria de processos, essas áreas corporativas têm sentimento de participação conjunta na proposta do novo processo, conhecendo melhor seu papel e conseqüências de suas respectivas atividades no todo do processo.

\section{- Melhoria de processos}

Em geral, as grandes empresas de varejo atuam em melhoria contínua de processos, sem ter vivenciado iniciativas estruturadas do tipo Lean Production, Kaizen ou Six Sigma. Por sua vez, as empresas que tentaram implementar qualquer iniciativa ligada a reengenharia de processos não teve o sucesso esperado e, portanto, definitivamente esta não é uma prática aplicada. Conforme destacado na literatura, a reengenharia de processos é considerada obsoleta e impraticável dada sua visão radical e histórico anterior de falhas e problemas (SEETHAMRAJU; MARJANOVIC, 2009).

Quanto à coleta de informações, todas empresas buscam entrevistar diretamente os usuários dos processos, sem intermediários. Por outro lado, não há consenso entre as empresas sobre metodologia específica para realizar entrevista. A empresa A, por exemplo, utiliza a metodologia $5 \mathrm{~W} 2 \mathrm{H}$, similar ao exposto por Ungson e Walsh (1991), sendo bastante detalhista à respeito das atividades enquanto que a empresa $\mathrm{B}$ e $\mathrm{C}$, cada uma a sua maneira, procuram obter as informações suficientes conforme respectiva metodologia de melhoria de processos. Finalmente, diversos trabalham destacam a importância da participação de envolvidos na proposta de novo processo (OLIVEIRA, 2006; SENTANIN et al., 2008; JULIEN; TJAHJONO, 2009). Nos casos estudados, todas empresas valorizam participação dos envolvidos principalmente para coletar e analisar viabilidade de possíveis oportunidades de melhoria além de conseguir comprometimento na implementação do novo processo.

Dentro dos projetos de melhoria, os processos possuem donos formalmente atribuídos, podendo ou não ser divulgados para todos os níveis hierárquicos. Este dono do processo é responsável pelo acompanhamento das atividades daquele processo e participa ativamente de todo projeto de melhoria de processo. Conforme Hammer (2002), ele é um dos responsáveis por monitorar e controlar os principais indicadores, além de gerenciar correções de pequenos imprevistos, e por direcionar questões evidentes que despontem no desenrolar do processo.

\section{- Implementação de melhoria de processos}

Constata-se nos casos estudados que empresas não possuem consenso quanto à metodologia para melhoria de processos. Cada uma delas adaptou metodologias existentes à cultura e realidade da empresa, somando ainda boas práticas de mercado e experiência da 
equipe. Conforme Seethamraju e Marjanovic (2009), cada metodologia tem suas vantagens e desvantagens, e nenhum modelo único é o melhor para todas as situações de negócio uma vez que as metodologias sempre dependem do contexto onde são aplicadas. Alguns autores (ADESOLA; BAINES, 2005; BATEMAN, 2005; DOOMUN; JUNGUM, 2008; MCKAY ; RADNOR, 1998) comentam sobre diferentes fases de metodologia de melhoria de processos. Em geral, a empresa A e C possuem etapas definidas na metodologia de melhoria de processo, diferente da empresa B que não possui etapas formalmente nominadas, mas tem bastante foco e disciplina em obter soluções práticas, de simples implementação, com ganhos rápidos, embasados por estudos históricos da realidade.

Cada uma das grandes empresas de varejo vivenciam em maior ou menor grau as dificuldades de implementação de melhorias de processos levantadas no referencial teórico. Assim, podemos resumir as principais observações realizadas:

$\rightarrow$ humanas: há pouca resistência de colaboradores visto que áreas envolvidas participam desde o início na proposta de novo processo;

$\rightarrow$ de tempo e recursos financeiros: devido à falta de tempo, pode-se preferir implantar "solução boa" em detrimento da "solução ótima", além disso área de Processos são dependentes de financiamento para desenvolver projetos de melhoria;

$\rightarrow$ técnicas, de tecnologia e metodologia: dependência da capacidade e prazo da área de TI para atender novas demandas além das dificuldades técnicas para realização de treinamento no novo processo (lojas em todo Brasil, regionalidades, alto índice de rotatividade e disponibilidade dos colaboradores de chão de loja);

$\rightarrow$ política e gestão: dificuldades de comunicação (loja e matriz, transição de liderança de projeto) e perda de informação ao longo do tempo (alta rotatividade de colaboradores de loja, grande quantidade de lojas a serem treinadas e questões culturais conforme região do país onde a loja esteja presente);

Da mesma forma, cada uma das grandes empresas de varejo destacam fatores críticos de sucesso na implementação de melhorias de processos, conforme referencial teórico. Podemos resumir as principais observações realizadas:

$\rightarrow$ apoio da alta gestão: para todas as empresas, a área de Processos está atrelada e tem apoio de alta hierarquia;

$\rightarrow$ alinhamento estratégico: projetos de melhoria de processos para melhorar resultados da empresa mas não necessariamente alinhado a objetivos estratégicos;

$\rightarrow$ avaliação de desempenho e efeito de demonstração: todas empresas percebem a importância de demonstrar rapidamente os resultados da melhoria para a empresa, 
no entanto, somente empresas B e C consideram fundamental utilizar dados concretamente atingidos para efeito de demonstração;

$\rightarrow$ presença de liderança: para todos casos área de Processos, responsável pela metodologia, é neutra, animando debates e mediando as partes envolvidas, associando seu papel como facilitadora na promoção das melhorias de processo;

$\rightarrow$ uso efetivo de tecnologia de informação: utilização de softwares para registrar processos mapeados ou ainda como apoio para melhorar ou monitorar processo;

$\rightarrow$ comunicação e transferência de conhecimento: preocupação em elaborar documentação padrão para comunicação às lojas e áreas corporativas com foco no usuário, divulgando processos principalmente através de intranet da empresa; atenção para transição de dono do processo, ou ainda de líder de projeto de melhoria de processo, para garantir comprometimento do novo gestor;

$\rightarrow$ rigor na implementação de melhorias: todas empresas valorizam planejamento e estruturação de etapas de atuação adaptados à necessidade de cada caso, porém somente as empresas A e C possuem metodologia formal para melhoria de processos, ou seja, é importante ter disciplina para implementar melhorias mas não necessariamente pautada por metodologia fixa;

$\rightarrow$ gestão da mudança em recursos humanos: destaque para trabalho de bastidores da área de Processos diminuindo resistências ao novo processo convidando envolvidos a redefinir atividades e reconstruir procedimentos;

$\rightarrow$ seleção criteriosa de colaboradores: todos casos valorizam participação de envolvidos na definição de novo processo e atribuição de dono de processo presente no dia a dia de sua atuação; destaca-se empresa $\mathrm{C}$ buscando apoio de áreas capazes de intermediar orientações da matriz e realidade do dia a dia de loja;

$\rightarrow$ concorrência de mercado: universo de varejo tem cultura de dinamismo e exige resultados em curto prazo, além disso projetos de melhoria de processos dependem da realidade vivenciada pela empresa (como por exemplo quantidade de lojas em todo Brasil, regionalidades do território nacional e turnover de colaboradores);

\section{- Indicadores}

Em geral, nos casos em que há definição formal de indicadores, estes são escolhidos apenas para criar histórico de dados permitindo analisar e avaliar potencial de melhoria contínua daquele processo. Os casos mostram que os indicadores não são formalmente alinhados com a perspectiva estratégica da empresa ou ainda relacionados ao cliente final. 


\section{CONCLUSÕES}

Este trabalho de pesquisa busca responder a seguinte questão de pesquisa: como grandes empresas do setor de varejo brasileiro atuam para implementar melhoria de processos?

Outras questões relacionadas foram propostas para embasar ou ainda complementar o estudo: como estas empresas definem processos, efetuam mapeamento dos mesmos e quais destes são selecionados para serem melhorados? Como estas empresas planejam e organizam atividades para efetuar melhoria de processos? Quais dificuldades e fatores críticos de sucesso para implementação de melhoria de processos? Como as empresas utilizam indicadores para constatar a melhoria dos processos?

Visando desenvolver estas perguntas realizou-se estudo de caso de três grandes empresas do varejo brasileiro que praticam melhoria de processos. A partir da análise cruzadas dos casos e relacionando-os com a literatura (vide Apêndice B) alguns fatos importantes são evidentes em face da atuação das empresas para implementarem melhoria de processos.

É importante destacar que de forma geral, as grandes empresas de varejo estudadas possuem cultura de processos recente e nível inicial de conceitos de processos aplicados conforme maturidade da empresa frente a conhecimentos de qualidade. Estas empresas possuem área de Processos dedicada à melhoria contínua de processos, sendo esta área a principal detentora dos conceitos de processo. Ficou evidente no estudo que primeiramente as empresas escolhem os processos a serem melhorados - geralmente processos administrativos e de suporte da empresa, não necessariamente relacionadas diretamente ao modelo de negócio da organização ou ainda ao cliente final - para em seguida realizar mapeamento dos mesmos. No entanto estes processos escolhidos não estão necessariamente alinhados com objetivos estratégicos da empresa, pois na verdade, a escolha depende simplesmente do interesse da área patrocinadora daquele projeto de melhoria de processos.

A atuação da área de Processos acontece de forma coordenada e disciplinada na melhoria de processos, valorizando planejamento antes da execução, sem perder foco no resultado final desejado. Destaca-se seu importante papel como órgão que estrutura processos, promovendo parcerias entre as áreas e sentimento de participação conjunta para coletar e analisar viabilidade de possíveis oportunidades de melhoria, além de conseguir comprometimento dos envolvidos na implementação do novo processo. 
Vale ressaltar que não há consenso quanto à metodologia específica para melhoria de processos, mas sim adaptação de metodologias existentes à cultura e realidade da empresa, somando ainda boas práticas de mercado e experiência da equipe. Dentro dos projetos de melhoria, os processos possuem donos formalmente atribuídos, responsáveis por sua execução, podendo ou não ser divulgados para todos os níveis hierárquicos da empresa.

Ao implementar melhoria de processos, constatou-se também que as empresas vivenciam, cada uma a sua maneira, as dificuldades (humanas; tempo e recursos financeiros; técnica, de tecnologia e metodologia; política e gestão) e fatores críticos de sucessos (apoio da alta gestão; alinhamento estratégico; avaliação de desempenho e efeito de demonstração; presença de liderança; uso efetivo de tecnologia de informação; comunicação e transferência de conhecimento; rigor na implementação de melhorias; gestão da mudança em recursos humanos; seleção criteriosa de colaboradores; e concorrência de mercado) levantados no referencial teórico.

Por sua vez, nos casos em que há definição de indicadores, estes não são formalmente alinhados com a perspectiva estratégica da empresa ou ainda relacionados ao cliente final, sendo escolhidos apenas para criar histórico de dados permitindo analisar e avaliar potencial de melhoria contínua daquele processo.

Apesar de relativamente bem encaminhadas, as empresas ainda possuem um caminho a percorrer para atingir maturidade na gestão por processos e buscar melhorar processos que agregam valor direto ao cliente final.

Finalmente, dentro dos limites deste estudo, o autor considera os objetivos da pesquisa atingidos dado que a avaliação de referencial teórico, juntamente com o método de pesquisa adotado e os resultados obtidos, permitem responder adequadamente à pergunta de pesquisa. Pode-se afirmar que futuros estudo de casos que analisem como outras empresas varejistas brasileiras ou estrangeiras atuam na melhoria de processos contribuirão para a generalização das conclusões. 


\section{REFERÊNCIAS BIBLIOGRÁFICAS}

ABDOLVAND,N.; ALBADVI, A.; FERDOWSI, Z. Assessing readiness for business process reengineering. Business Process Management Journal, n. 4, v. 14, p. 497-511, 2008.

ADESOLA, S.; BAINES, T. Developing and evaluating a methodology for business process improvement. Business Process Management Journal. n. 1, v. 11, p. 37-46, 2005.

AGUILAR-SAVEN, R. Business process modelling: review and framework. International Journal of Production Economics, n.2, v. 90, p. 129-149, 2003.

AHIRE, S.L.; DREYFUS, P. The impact of design management and process management on quality: an empirical investigation. Journal of Operations Management, v.18, p..549-575, 2000 .

AHMAD, H.; FRANCIS, A.; ZAIRI, M. Business process reengineering: critical success factors in higher education. Business Process Management Journal, n. 3, v. 13, p. 451-469, 2007.

AL-HUDHAIF, S. A. Process redesign: reengineering core process at computer department a case of SWCC. Business Process Management Journal. n. 2, v. 15, p. 184-200, 2009.

AL-MASHARI, M.; ZAIRI, M. BPR implementation process: an analysis of key success and failure factors. Business Process Management Journal, n. 1, v. 5, p. 87-112. 1999.

AL-MASHARI, M.; ZAIRI, M. Revisiting BPR: a holistic review of practice and development. Business Process Management Journal, n. 1, v. 6, p. 10-42, 2000.

AL-MUDIMIGH, A. S. The role and impact of business process management in enterprise systems implementation. Business Process Management Journal, n. 6, v. 13,p. 866-874, 2007.

BALDWIN, L.P., TILLAL, E.; RAY, J.P. Business process design: flexible modelling with multiple levels of detail. Business Process Management Journal, n. 1, v. 11, p. 22-36, 2005.

BARBER, K.D., DEWHURST, F.W., BURNS, R.L.D.H. and ROGERS, J.B.B. Businessprocess modelling and simulation for manufacturing management: a practical way forward. Business Process Management Journal, n. 4, v. 9, p. 527-542, 2003. 
BATEMAN, N. Sustainability: the elusive element of process improvement. International Journal of Operations \& Production Management, v. 25, n. 3, p. 261-276. 2005.

BERENTE,N.; VANDENBOSCH,B.; AUBERT, B. Information flows and business process integration. Business Process Management Journal, n. 1, v. 15, p. 119-141, 2009.

BIAZZI, M. R. Instituições públicas de ensino superior: estudo de casos de aperfeiçoamento de processos administrativos. 2007. 177p. Dissertação (Mestrado) - Escola Politécnica, Universidade de São Paulo, São Paulo, 2007.

BOYLE, R.D. Avoiding common pitfalls of reengineering. Management Accounting, n. 4, v. 77, p. 24-33, 1995

BROCKE, J.; RECKER, J.; MENDLING, J. Value-oriented process modeling: integrating financial perspectives into business process re-design. Business Process Management Journal, n.2, v.16, p. 333-356, 2010.

CARMIGNANI, G. Process-based management: a structured approach to provide the best answers to the ISO 9001 requirements. Business Process Management Journal. n.6, v.14, p. 803-812, 2008

CHAN, K.K.; SPEDDING, T.A. An integrated multidimensional process improvement methodology for manufacturing systems. Computers \& Industrial Engineering, v. 44, p. 673693, 2003.

CHEW, M.; CHENG, J.; PETROVIC-LAZAREVIC, S. Managers role in implementing organisational change: case of the restaurant industry in Melbourne. Journal of Global Business and Technology, n. 1, v. 2, p. 58-67, 2006.

CLIMENT, C.; MULA, J.; HERNÁNDEZ, J. E. Improving the business processes of a bank. Business Process Management Journal. n. 2, v. 15, p. 201-224, 2009.

COSKUN, S.; BASLIGIL H.; BARACLI, H. A weakness determination and analysis model for business process improvement. Business Process Management Journal, n. 2, v. 14, p. 243261,2008

DALE, B.G. A framework for the introduction of a process of quality improvement in retail organizations. International Journal of Retail \& Distribution Management, n.8, v. 22, p.25-32, 1994. 
DAMIJ, N. Business process modelling using diagrammatic and tabular techniques. Business Process Management Journal, n. 1, v. 13, p. 70-90, 2007.

DAMIJ, N. ; DAMIJ,T.; GRAD, J.; JELENC, F. A methodology for business process improvement and IS development. Information and Software Technology, v.50, p.1127-1141, 2008.

DONNER, M., ELLIS, T. and SWIFT, K. A technique for revealing and agreeing an agenda for process improvement. Journal of Materials Processing Technology, v. 118, p. 216-218, 2001.

DOOMUN, R.; JUNGUM, N.V.; Business process modelling, simulation and reengineering: call centres. Business Process Management Journal, n.6, v. 14 p. 838-848, 2008

DAVENPORT, T.H. Process Innovation. Boston: Harvard Business School Press, 1993. $337 \mathrm{p}$.

EISENHARDT, K.M. Building theories from case study research. The Academy of Management Review, n.4, v.14, p.532-550, 1989.

FISHER, J.M. A time for change? Human Resource Development International, n. 2, v. 8, p. 257-263, 2005.

GARGEYA, V.B.; BRADY, C. Success and failure factors of adopting SAP in ERP system Implementation. Business Process Management Journal, n. 5, v. 11, p. 501-516, 2005.

GARVIN, D.A. The process of organization and management. Sloan Management Review, n.4, v. 39, p. 33-50, 1998

General Management: processes and action. Boston: McGraw Hill, 2002. 630 p.

GEORGE, M. Lean six sigma for service: how to use lean speed and six sigma quality to improve services and transactions. New York: McGraw-Hill, 2003.

GREWAL, D.; LEVY, M. Retailing research: Past, present, and future. Journal of Retailing, n.4, v.83, p. 447-464, 2007 
GIAGLILS, G.M. A taxonomy of business process modelling and information system modelling techniques. International Journal of Flexible Manufacturing Systems, n. 2, v. 13, p. 209-228, 2001.

GOLDKUHL, G.; LIND, M. Coordination and transformation in business processes: towards an integrated view. Business Process Management Journal, n. 6, v.14, p. 761-777, 2008

GONZÁLEZ, L. S.; RUBIO, F. G.; GONZÁLEZ, F. R.; VELTHUIS, M. P. Measurement in business processes: a systematic review. Business Process Management Journal, n.1, v.16, p. 114-134, 2010.

GROVER, V., JEONG, S.R., KETTINGER, W.J.; TENG, J.T.C. The implementation of business process reengineering. Journal of Management Information Systems, n. 1, v. 12, p. 109-144. 1995.

GULLEDGE, J.R.; SOMMER, R.A. Business process management: public sector implications. Business Process Management Journal, n.4, v. 8, p. 364-376, 2002.

GUPTA, A. Enterprise resource planning: the emerging organizational value systems. Industrial Management \& Data Systems, n. 3, v.100, p. 114-118, 2000.

HACKMAN, K. Beyond administration: redefining the challenge of regulatory change. Strategic Change, n. 1, v. 16, p. 1-9. 2007.

HAMMER, M. Process management and the future of six sigma. Sloan Management Review, Massachusetts, n. 2, v. 43, p. 26-32., 2002.

HAMMER, M.; CHAMPY,J. Reengineering the corporation: a manifesto for business revolution. New York: Harper Business, 1993. 223p.

HANAFIZADEH,P.; MOAYER, S. A methodology to define strategic processes in organizations: an exploration study in managerial holding companies. Business Process Management Journal, n. 2, v. 14, p. 219-227, 2008.

HANAFIZADEH, P.; MOOSAKHANI,M.; BAKHSHI, J. Selecting the best strategic practices for business process redesign. Business Process Management Journal, n.4, v.15, p. 609-627, 2009.

HECKL, D.; MOORMANN, J. How to design customer-centric processes in the banking industry. Journal of Financial Transformation, v. 21, p. 67-76, 2007 
HECKL, D.; MOORMANN, J.. ROSEMANN, M. Surveying the critical success factors of BPM-systems implementation. Business Process Management Journal, n.3, v.16, p. 436-472, 2010.

HESSON, M.; AL-AMEED, H.; SAMAKA, M. Business process reengineering in UAE public sector: a town planning case study. Business Process Management Journal, n. 3, v. 13, p. 348-378, 2007

HINER, P.; RICH, N. The seven value stream mapping tools. International Journal of Operations \& Production Management, v. 17, p. 146-164, 1997.

HOUY, C.; FETTKE, P.; LOOS, P. Empirical research in business process management analysis of an emerging field of research. Business Process Management Journal, n.4, v.16, p. 619-661, 2010.

JULIEN, D. M.; TJAHJONO, B. Lean thinking implementation at a safari park. Business Process Management Journal, n. 3, v. 15, p. 321-335, 2009.

KAMHAWI , E. M. Determinants of Bahraini managers' acceptance of business process reengineering. Business Process Management Journal, n. 2, v. 14, p. 166-187, 2008.

KELLER, P.J.; JACKA, J.M. Process mapping. Internal Auditor, v. 56, n. 5, p. 60-64, 1999.

KETTINGER, W.J.; TENGE, J.T.C.; GUHA, S. Business process change: a study of methodologies, techniques and tools. MIS Quarterly, n. 1,v. 21, p. 55-80,1997.

KLASSEN, R.D.; MENOR, L.J. The process management triangle: an empirical investigation of process trade-offs. Journal of Operations Management, n.25, p. 1015-1034, 2007.

KLEIN, M.; PETTI, C. A handbook-based methodology for redesigning business processes. Knowledge and Process Management, n. 2, v. 13, p. 108-119, 2006.

KOHLBACHER, M. The effects of process orientation: a literature review. Business Process Management Journal, n.1, v.16, p. 135-152, 2010.

KUMAR, P. The competitive impact of service process improvement: Examining customers' waiting experiences in retail markets. Journal of Retailing, n.3, v. 81, p. 171-180, 2005. 
KUMAR,V.; MOVAHEDI, B.; LAVASSANI, K. M.; KUMAR,U. Unleashing process orientation A comparative study of enterprise system implementation in Canadian and US firms. Business Process Management Journal, n.2, v.16, p. 315-332, 2010.

KÜNG, P.; HAGEN, C. The fruits of Business Process Management: an experience report from a Swiss bank. Business Process Management Journal, n. 4, v. 13, p. 477-487, 2007

LACERDA, D. P.; CASSEL, R. A.; RODRIGUES, L.H. Service process analysis using process engineering and the theory of constraints thinking process. Business Process Management Journal, n.2, v.16, p. 264-281, 2010.

LASA, I. S.; LABURU C. O.; VILA, R. C. An evaluation of the value stream mapping tool. Business Process Management Journal. n. 1, v. 14, p. 39-52, 2008.

LEE, K.T. ; CHUAH, K.B. A super methodology for business process improvement: an industrial case study in Hong Kong (China). International Journal of Operations \& Production Management, n. 5/6, v. 21, p. 687-706, 2001

LIN, F.R.; YANG, M.C.; PAI, Y.H. A generic structure for business process modelling. Business Process Management Journal, n. 1, v. 8, p. 19-41, 2002.

LOK, P., HUNG, R.Y., WALSH, P., WANG, P. and CRAWFORD, J. An integrative framework for measuring the extent to which organizational variables influence the success of process improvement programmes. The Journal of Management Studies, n. 7, v. 42, p. 1357$1381,2005$.

MANSAR, S. L.; REIJERS, H.A. Best practices in business process redesign: use and impact. Business Process Management Journal, n. 2, v. 13,p. 193-213, 2007.

MACDONALD, J. Together TQM and BPR are winners. The TQM Magazine, n. 3, v. 7, p. 21-25, 1995.

MACINTOSH, R. BPR: alive and well in the public sector. International Journal of Operations \& Production Management, n. 3, v. 23, p. 327-344, 2003.

MCKAY, A.; RADNOR, Z. A characterization of a business process. International Journal of Product Management, n. 910, v. 18, p. 924-936, 1998.

MIGUEL, P.A.C. Estudo de caso na engenharia de produção: estruturação e recomendações para sua condução. Produção, n. 1, v. 17, p. 216-229, Jan./Abr. 2007. 
MIGUEL, P. A.C. Adoção do estudo de caso na engenharia de produção. In: MIGUEL, P.A.C. (coord.). Metodologia de pesquisa em engenharia de produção e gestão de operações. Rio de Janeiro: Elsevier, 2010.

NEUBAUER, T. An empirical study about the status of business process management. Business Process Management Journal, n.2, v.15, p. 166-183, 2009.

NIEHAVES, B. Open process innovation: the impact of personnel resource scarcity on the involvement of customers and consultants in public sector BPM. Business Process Management Journal, n.3, v.16, p. 377-393, 2010.

OLIVEIRA, D.P.R. Administração de processos. São Paulo: Atlas, 2006. 291p.

PAPER, D.. RODGER, J.; PENDHARKAR, P. A BPR case study at Honeywell. Business Process Management Journal, n. 2, v. 7, p. 85-99, 2002.

PAIM, R.; CAULLIRAUX, H. M.; CARDOSO, R.Process management tasks: a conceptual and practical view. Business Process Management Journal, n. 5, v. 14, p. 694-723, 2008.

PALMBERG,K. Exploring process management: are there any widespread models and definitions?. The TQM Journal, n. 2, v. 21, p. 203-215, 2009.

Experiences of implementing process management: a multiple-case study. Business Process Management Journal, n.1, v.16, p. 93-113, 2010.

PARADISO, J. The essential process; Industrial Engineer, v. 35, n. 4, p. 46-48, 2003.

PARENTE,J. Varejo no Brasil: gestão e estratégia. São Paulo: Atlas, 2000. 388p.

PEIXOTO, L.J.S. Implementação de modelo de gestão por processos utilizando equipes autogeridas em uma agência da previdência social: estudo de caso. 2006. 103p. Dissertação (Mestrado) - Faculdade de Economia, Administração e Contabilidade, Universidade de São Paulo, São Paulo, 2006.

PEPPARD, J.; FITZGERALD, D. The transfer of culturally-grounded management techniques: the case of business process reengineering in Germany. European Management Journal, n. 4, v. 15, p. 446-460, 1997. 
POVEY, B. The development of a best practice business process improvement methodology. Benchmarking for Quality Management \& Technology, n. 1, v. 5,p. 27-44, 1998.

REIJERS, H.A. Implementing BPM systems: the role of process orientation", Business Process Management Journal, n. 4, v. 12, p. 389-409, 2006.

REVERE, L. Re-engineering proves effective for reducing courier costs. Business Process Management Journal, n.4, v. 10, p. 400-414, 2004.

ROTONDARO, R. G.; CARVALHO, M.M (coord.).;PALADINI,E.P.(coord.) et al. Gestão da qualidade: teoria e casos. São Paulo: Campus/Elsevier, 2006a. 355p.

ROTONDARO, R. G. Identificação, análise e melhoria dos processos críticos. In: LAURINDO, F.J.B. (coord.); ROTONDARO, R. G.(coord.) et al. Gestão integrada de processos e da tecnologia da informação. São Paulo: Atlas, 2006b. 218p.

ROTONDARO, R. G. Gerenciamento por processos. In: CONTADOR J.C.(coord.). Gestão de operações. 2. ed. São Paulo: Blücher, 1998. 593p.

RUMMLER, G. A.; BRACHE, A. P. Melhores desempenhos das empresas - ferramentas para a melhoria da qualidade e da competitividade. São Paulo: Makron Books, 1992.

SALLOWICZ, M.; ROLLI, C. Concentração de supermercados sobe e chega a $46 \%$ no país. Folha de São Paulo, 01 jul. 2011. Mercado. Disponível em: http://www1.folha.uol.com.br/mercado/937299-concentracao-de-supermercados-sobe-echega-a-46-no-pais.shtml Acesso em: 01 jul. 2011

SAVORY, P.; OLSON, J. Guidelines for using process mapping to aid improvement efforts. Hospital Material Management Quarterly, v. 22, n.3, p. 10-16, 2001.

SENTANIN,O.F.; SANTOS, F.C.A.; JABBOUR, C.J.C. Business process management in a brazilian public research centre . Business Process Management Journal, n.4, v.14, p. 483496, 2008.

SEETHAMRAJU, R.; MARJANOVIC, O. Role of process knowledge in business process improvement methodology: a case study. Business Process Management Journal, n. 6, v. 15, p. 920-936, 2009. 
SHIN, N.; JEMELLA, D.F. Business process reengineering and performance improvement: the case of Chase Manhattan Bank. Business Process Management Journal, n. 4, v. 8, p. 35163, 2002.

SIDOROVA, A.; ISIK, O. Business process research: a cross-disciplinary review. Business Process Management Journal, n.4, v.16, p. 566-597, 2010.

SIHA, S. M.; SAAD, G. H. Business process improvement: empirical assessment and extensions. Business Process Management Journal, n. 6, v. 14, p. 778-802, 2008.

ŠKRINJAR, R.; BOSILJ -VUKŠIĆ, V.; INDIHAR-ŠTEMBERGER, M. The impact of business process orientation on financial and non-financial performance. Business Process Management Journal, n. 5, v. 14, p. 738-754, 2008

SMITH, M. Business process design: correlates of success and failure. The Quality Management Journal, n. 2, v. 10, p. 38-49, 2003.

STODDARD, D.B., JARVENPAA, S.L.; LITTLEJOHN, M., The reality of business reengineering: Pacific Bell's Centrex provisioning process. California Management Review, n. 3, v. 38, p. 57-76, 1996

SUNG, T.K.; GIBSON, D.V. Critical success factors for business reengineering and corporate performance: the case of Korean corporations. Technological Forecasting and Social Change, n. 2, v. 58, p. 297-311, 1998.

TAM, A.S.M., CHU, L.K. and SCULLI, D. Business process modelling in small- to mediumsized enterprises. Industrial Management \& Data Systems, v. 101, p. 144-152, 2001

TAX, S.S.; STUART, I. Designing and implementing new services: the challenges of integrating service systems. Journal of Retailing, n.1, v.73, p.105-134, 1997.

TERZIOVSKI, M., FITZPATRICK, P.; O'NEILL, P, Successful predictors of business process reengineering (BPR) in financial services. International. Journal of Production Economics, n. 1, v. 84, p. 35-50, 2003.

TSIM, Y.C.. YEUNG, V.W.S.. LEUNG, E.T.C. An adaptation to ISO 9001:2000 for certified organizations. Managerial Auditing Journal, n.5, v.17, p. 245-250, 2002.

UNGSON, G. R.; WALSH, J. P. Organisation memory. Academy of Management Review, n.1, v.16, p.57-91, 1991. 
VAKOLA, M.; REZGUI, Y. Critique of existing business process re-engineering methodologies - the development and implementation of a new methodology. Business Process Management Journal, n. 3, v. 6, p. 238-250, 2000.

VALIRIS, G., GLYKAS, M. Critical review of existing BPR methodologies the need for a holistic approach. Business Process Management Journal, n. 1, v. 5, p. 65-86, 1999.

VAN DER AALST, W.M.P. Business process management - a personal view. Business Process Management Journal, n. 2, v. 10, p. 135-9, 2004.

VOSS, C. et al. Case Research in Operations Management. International Journal of Operations and Production Management, n. 2, v.22, p. 195-219, 2002.

WELLS, M.G. Business process re-engineering implementations using internet technology. Business Process Management Journal, n. 2, v. 6, p. 164-184, 2000.

WU, I.L. A model for implementing BPR based on strategic perspective: an empirical study. Information and Management, v. 39, p. 313-324, 2002.

YEN, V. C. An integrated model for business process measurement. Business Process Management Journal, n.6, v.15, p. 865-875, 2009

YIN, R.K. Estudo de caso: planejamento e métodos. 3 ed. Porto Alegre: Bookman, 2005.

ŽABJEK,D.; KOVAČIČ,A.; ŠTEMBERGER, M.I. The influence of business process management and some other CSFs on successful ERP implementation. Business Process Management Journal, n. 4, v. 15, p. 588-608, 2009.

ZAIRI, M.; SINCLAIR, D. Business process re-engineering and process management: a survey of current practice and future trends in integrated management", Management Decision, n. 3, v. 33, p. 3-16, 1995. 


\section{APÊNDICE A - QUESTIONÁRIO DE PESQUISA}

\section{Questionário de Pesquisa de Mestrado \\ “MELHORIA DE PROCESSOS EM EMPRESAS DO SETOR DE VAREJO NO BRASIL: ESTUDO DE CASOS"}

Empresa:

Entrevistado:

Cargo:

(Diretor, Gerente Sênior, Média Gerência, Coordenador, Consultor, Analista)

\section{$\underline{\text { I-Entendimento Geral }}$}

1. Existe área dedicada para melhoria de processos? Desde quando? Dedica-se exclusivamente a isso? (Descrever mais informações se julgar necessário)

2. Qual área "patrocina" o escritório de processos? (Descrever mais informações se julgar necessário)

3. Qual estrutura hierárquica da área? Quantos colaboradores? (Diretores, Gerência sênior, Média Gerência, Consultores ou Especialistas, Analistas)

4. Qual abrangência de atuação da área de processos na empresa? (Escolher uma das alternativas abaixo)
a) Uma única área
b) Mais de uma área
c) Empresa inteira

5. A empresa possui a cultura de processos amplamente divulgada e reconhecida pelos colaboradores? (Descrever mais informações se julgar necessário)

6. Existem ou existiram outras iniciativas ligadas a processos na empresa? (Escolher mais de uma das alternativas abaixo se necessário)

- Gestão da Qualidade Total (Total Quality Management-TQM) Sim Não

- Lean Production Sim Não

- Kaizen Sim Não

- Six Sigma $\quad$ Sim Não

- Reestruturação baseada em processos (Reengenharia de processos) Sim Não

(Descrever mais informações se julgar necessário) 


\section{$\underline{\| \text { - Processos }}$}

7. A empresa possui definição formal de processos? Qual é esta definição? Como é aplicada? (Descrever mais informações se julgar necessário)

8. Como a empresa faz para formalizar e documentar processos? Utiliza ferramenta específica para mapeamento, modelagem e melhoria de processos?

9. Os processos possuem formalmente gestores definidos e comunicados para a empresa? (Descrever mais informações se julgar necessário)

10. Qual(is) critério(s) a empresa utiliza para selecionar processos a serem melhorados? Como estes processos são alinhados frente aos objetivos estratégicos da empresa? (Descrever mais informações se julgar necessário)

11. Qual nível de maturidade de implementação de processos?

- Documentação

- Mapeamento e implementação de melhorias

- Controle (gestor e indicadores definido e comunicado)

- Remuneração atrelada aos indicadores de processos mapeados
Sim Não

Sim Não

Sim Não

$\operatorname{Sim} \quad$ Não

(Descrever mais informações se julgar necessário)

12. Como acontece o envolvimento das áreas em projetos de melhoria de processos? Quem é responsável pela condução destes projetos? (Descrever mais informações se julgar necessário)

13. A empresa utiliza metodologia de melhoria contínua ou de melhoria por ruptura? (Descrever mais informações se julgar necessário)

14. A empresa possui metodologia própria específica para melhoria de processos? (Descrever mais informações se julgar necessário)

15. A empresa utiliza consultoria externa para prestação de serviços de melhoria de processos? (Escolher uma das alternativas abaixo)

- Todos os projetos

- Metade dos projetos

- Alguns projetos

- Nenhum projeto 
III-Dificuldades e Fatores Críticos de Sucesso

16. Quais as dificuldades encontradas para implementação de melhoria de processos? (Descrever mais informações se julgar necessário)

\begin{tabular}{|c|c|}
\hline Dificuldades & Definição \\
\hline Humanas & $\begin{array}{l}\text { - } \text { resistência das pessoas; } \\
\text { - equipes ineficazes da área de processos nas empresas; } \\
\text { - relutância de colaboradores em cessar ou reduzir algumas de suas } \\
\text { responsabilidades de decisão; } \\
\text { - medo de perder emprego e autoridade sobre os empregados; } \\
\text { - resistência dos usuários para modificações devido a descrença sobre os } \\
\text { resultados do projeto }\end{array}$ \\
\hline Tempo e Recursos Financeiros & $\begin{array}{l}\text { - tempo necessário para implementação da metodologia; } \\
\text { - disponibilidade de recursos financeiros; } \\
\text { - custos de aplicação associados }\end{array}$ \\
\hline $\begin{array}{l}\text { Técnica, de Tecnologia e } \\
\text { Metodologia }\end{array}$ & $\begin{array}{l}\text { - aspectos técnicos da mudança; } \\
\text { - problemas relacionados a TI; } \\
\text { - dificuldades em modelar aspectos organizacionais dentro de uma } \\
\text { metodologia; } \\
\text { - dificuldades em modelar fatores humanos dentro de uma metodologia; } \\
\text { - falta de habilidade das empresas para avaliar os efeitos das melhorias de } \\
\text { processos mapeados antes de sua implementação; } \\
\text { - falta de conhecimento sobre benefícios potenciais da metodologia; } \\
\text { processos de definidos de forma inapropriada (muito ampla ou muito } \\
\text { estreita); }\end{array}$ \\
\hline Política e Gestão & $\begin{array}{l}\text { - falta de apoio e comprometimento da alta gestão; } \\
\text { - falta de gestão de projetos; } \\
\text { - falta de gestão na implementação de mudanças; } \\
\text { - falta de habilidade de generalizar questões transversais a diversas situações } \\
\text { de negócio; } \\
\text { - liderança indecisa } \\
\text { - ausência de objetivos mensuráveis; } \\
\text { - problemas de comunicação; } \\
\text { - desconforto com novo ambiente de trabalho; } \\
\text { - redundância de trabalho após a mudança; }\end{array}$ \\
\hline
\end{tabular}


17. Quais fatores são fundamentais para ter sucesso na implementação de melhoria de processos? (Descrever mais informações se julgar necessário)

\begin{tabular}{|c|c|}
\hline$F C S$ & Definição \\
\hline Apoio da alta gestão & $\begin{array}{l}\text { - envolvimento e comprometimento total, visível e bem definido da alta } \\
\text { administração, sentido por todos; } \\
\text { - valorização do projeto frente à empresa; } \\
\text { - participação nas tomadas de decisões }\end{array}$ \\
\hline Alinhamento estratégico & $\begin{array}{l}\text { - estabelecimento de planejamento estratégico para projetos de melhoria de } \\
\text { processos } \\
\text { - escolha precisa de processos a serem aperfeiçoados; }\end{array}$ \\
\hline $\begin{array}{l}\text { Avaliação de desempenho e } \\
\text { efeito de demonstração }\end{array}$ & $\begin{array}{l}\text { - medir desempenho de processos para investigar as conseqüências de } \\
\text { implementação de melhoria na empresa } \\
\text { - aumento de investimento em projetos cujas ações implementadas mostraram } \\
\text { resultados } \\
\text { - necessidade de evidências tangíveis e concretas de melhorias implementadas }\end{array}$ \\
\hline Presença de liderança & $\begin{array}{l}\text { - } \text { estabelecimento de gestão de projeto para iniciativas de melhoria de processos; } \\
\text { - liderança igualitária efetiva coordenando a distribuição e disponibilidade de } \\
\text { recursos; } \\
\text { - criação de ambiente de trabalho colaborativo; } \\
\text { - construção de relações melhores com principais interessados (funcionários, } \\
\text { clientes e fornecedores); } \\
\text { - envolver toda empresa buscando participação das partes envolvidas }\end{array}$ \\
\hline $\begin{array}{l}\text { Uso efetivo de tecnologia de } \\
\text { informação }\end{array}$ & $\begin{array}{l}\text { - ter capacidade e infra-estrutura de TI; } \\
\text { - utilização de sistemas de informação para obter, comparar e processar dados }\end{array}$ \\
\hline $\begin{array}{l}\text { Comunicação e transferência de } \\
\text { conhecimento }\end{array}$ & $\begin{array}{l}\text { - comunicação para suportar mudanças do processo } \\
\text { - ênfase em compartilhamento de conhecimento }\end{array}$ \\
\hline $\begin{array}{l}\text { Rigor na implementação de } \\
\text { melhorias }\end{array}$ & $\begin{array}{l}\text { - monitoramento de etapas de aplicação da metodologia; } \\
\text { - mudança de processos existentes, transformando práticas de negócio e } \\
\text { adaptando processo conforme necessidades do negócio; } \\
\text { - ter estrutura para impedir retrocesso a processos antigos }\end{array}$ \\
\hline $\begin{array}{l}\text { Gestão da mudança em recursos } \\
\text { humanos }\end{array}$ & $\begin{array}{l}\text { - treinamento contínuo de equipe para alcançar resultados desejados; } \\
\text { - redefinição de tarefas, eliminação e reconstrução de procedimentos, etc.; } \\
\text { - desenvolvimento de novas habilidades necessárias pelos novos processos; } \\
\text { - estabelecimento de sistemas de gestão para cultivar os valores exigidos e atingir } \\
\text { objetivos desejados }\end{array}$ \\
\hline $\begin{array}{l}\text { Seleção criteriosa de } \\
\text { colaboradores }\end{array}$ & $\begin{array}{l}\text { - escolher e motivar os funcionários certos para participarem na implementação } \\
\text { do processo; } \\
\text { - perfil de pessoas de alto nível de criatividade, educação, habilidade de lidar } \\
\text { com riscos e crença em mudança de processos; } \\
\text { - buscar forma adequada de incorporar facilitadores de melhoria de processos }\end{array}$ \\
\hline Concorrência de mercado & $\begin{array}{l}\text { - pressão de mercado competitivo } \\
\text { - fatores específicos do setor econômico da empresa }\end{array}$ \\
\hline
\end{tabular}




\section{VI-Projeto de Melhoria de Processos e Comentários Gerais}

18. Como foi a abordagem metodológica utilizada?

19. Como funcionava o processo antes ?

20. Quais áreas de negócio foram consultadas? Como foi a participação das áreas? Houve reuniões em conjunto para encontrar soluções? Como foram propostas as soluções? Em que elas foram baseadas? As soluções foram sugeridas somente pela área de Processos? Como fizeram para sugerir soluções? Qual o papel de cada uma das áreas neste processo?

21. Quais principais problemas encontrados durante a etapa de levantamento de informações?

22. Foram feitos fluxos do(s) processos? Qual é o passo a passo? Pode disponibilizar fluxo(s)?

23. Quem é o dono do processo?

24. O que foi feito para manter as soluções implementadas? Treinamento, divulgação, etc...? Existem dificuldades para manter? E para implementar, quais foram as dificuldades? E os fatores chave de sucesso?

25. Como foram implantados indicadores? Qual o critério de escolha de indicadores a serem medidos? Há algum alinhamento formal com estratégia da empresa? Quem os escolheu? Quem demandou? Os indicadores vieram de algum consenso entre áreas? Quem os monitora?

26. Qual sua análise geral sobre o caso? Qual a repercussão para as áreas?

27. Quais são as melhoria ainda a serem feitas neste processo? Por que ainda não foram feitas e o que precisa para fazê-las? 


\section{APÊNDICE B - CONSOLIDADO PARA ANÁLISE CRUZADA DOS CASOS}

\begin{tabular}{|c|c|c|}
\hline $\begin{array}{c}\text { Conceitos da } \\
\text { Literatura }\end{array}$ & Caso $A$ & Caso B \\
\hline (3.1) Processos & $\begin{array}{l}\text { - possui definição formal de processos como } \\
\text { conjunto de atividades que representam o } \\
\text { funcionamento da empresa; } \\
\text { - nível inicial de maturidade de conceitos e } \\
\text { cultura de processos; } \\
\text { - todos processos tem objetivo descrito de } \\
\text { forma padronizada, focada em agregar } \\
\text { valor para macro-processo do qual faz } \\
\text { parte, não necessariamente para o cliente } \\
\text { final; projetos de melhoria de processos } \\
\text { escolhidos conforme foco da área } \\
\text { patrocinadora, não sendo necessariamente } \\
\text { desdobramento do planejamento estratégico } \\
\text { da empresa; divalgação de processos somente via } \\
\text { intranet da empresa; }\end{array}$ & $\begin{array}{l}\text { - não há definição formal de processo; } \\
\text { - conceito de processo é claro para Presidência, e } \\
\text { para área de Qualidade e Processos diferente das } \\
\text { demais áreas em que carece de amadurecimento e } \\
\text { de consolidação; } \\
\text { - processos a serem melhorados são escolhidos } \\
\text { conforme orientação da Presidência, havendo } \\
\text { tendência de atuar naqueles ligados a objetivos da } \\
\text { empresa (por exemplo, redução de custos), mas } \\
\text { não necessariamente ligados ao cliente final; } \\
\text { - possui cadeia de valor mapeada superficialmente, } \\
\text { sendo maior atuação em processos administrativos, } \\
\text { não necessariamente ligados diretamente ao } \\
\text { negócio; } \\
\text { - divulgação de processos via email e intranet da } \\
\text { empresa; }\end{array}$ \\
\hline $\begin{array}{l}\text { (3.2) Gestão por } \\
\text { processos }\end{array}$ & $\begin{array}{l}\text { - atuação do Núcleo de Processos de forma } \\
\text { coordenada, seguindo metodologia própria } \\
\text { e estruturada para melhoria de processos; } \\
\text { - áreas corporativas atuam de forma } \\
\text { departamental, ou seja, executam atividades } \\
\text { sem necessariamente conhecer a visão do } \\
\text { todo do processo; } \\
\text { - após participação em projetos de melhoria } \\
\text { de processos, as áreas corporativas tomam } \\
\text { conhecimento do papel desempenhado e } \\
\text { das conseqüências de suas respectivas } \\
\text { atividades no todo do processo; }\end{array}$ & $\begin{array}{l}\text { - ações de melhoria eficazes a partir de atuação } \\
\text { estruturada e planejada da equipe de Qualidade e } \\
\text { Processos, evidenciando para áreas impacto de } \\
\text { suas atividades entre si; } \\
\text { - independente das dificuldades encontradas, foco } \\
\text { no resultado final esperado, procurando não se } \\
\text { desviar das atividades previamente estabelecidas; } \\
\text { - colaboradores seguem normas e procedimentos } \\
\text { estabelecidos, mas não tem a visão ampla de } \\
\text { entendimento sobre a origem da necessidade } \\
\text { daquela norma ou procedimento; } \\
\text { - em projetos de melhoria de processos, ocorre } \\
\text { definição de melhorias com principais usuários e } \\
\text { apresenta-se a proposta pré-estabelecida para obter } \\
\text { pequenas contribuições das demais áreas, criando } \\
\text { sentimento de participação conjunta. }\end{array}$ \\
\hline
\end{tabular}

Caso C

- não possui definição formal para processo, mas entende termo como encadeamento de atividades com início e fim;

funcionamento da empresa cultura de processos;

a processos é relativamente recente;

- melhoria de processos administrativos e de suporte da empresa;

- atuação em projetos de melhoria de processos conforme demanda das áreas, não necessariamente como desdobramento de objetivos pré-estabelecidos da empresa;

- busca satisfação de clientes internos da empresa, mas não necessariamente atua focado em melhorias para o cliente final;

- divulgação de processos via email e em intranet da empresa;

da empresa

atuação do Núcleo de Processos de forma onada, seguindo metodologia propria - departamental, ou seja, executam atividades sem necessariamente conhecer a visão do conhecimento do papel desempenhado consequências de suas respectivas definição de melhorias com principais usuários e pequenas contribuições das demais áreas, criando sentimento de participação conjunta. atuação da área de Processos de forma estruturada e disciplinada para cumprimento de etapas da metodologia, valorizando principalmente planejamento antes da execução;

- conforme há sucesso de implementação de melhorias, há conscientização das áreas de que para obter resultados concretos e direcionados é necessário planejamento;

áreas da empresa possuem uma visão vertical dos processos focada em seus próprios objetivos; 


\begin{tabular}{|c|c|c|c|}
\hline $\begin{array}{c}\text { Conceitos da } \\
\text { Literatura }\end{array}$ & Caso A & Caso B & Caso C \\
\hline $\begin{array}{l}\text { (3.3) Melhoria de } \\
\text { processos }\end{array}$ & $\begin{array}{l}\text { - atuação em melhoria contínua de processos, } \\
\text { sem ter vivenciado iniciativas estruturadas } \\
\text { do tipo Lean Production, Kaizen, Six } \\
\text { Sigma, mas empresa já passou por } \\
\text { reestruturação para redução de despesas; } \\
\text { - registro do fluxo do processo, com } \\
\text { elaboração de detalhamento funcional de } \\
\text { atividades segundo metodologia 5W2H, } \\
\text { apontando deficiências e oportunidades; } \\
\text { - validação de processos, através de } \\
\text { assinatura de todos participantes, nos } \\
\text { desenhos As Is e To Be; } \\
\text { - metodologia estruturada para mapeamento } \\
\text { de processos auxilia a evidenciar a visão do } \\
\text { todo, entendendo o encadeamento dos } \\
\text { processos para atingir o objetivo final; } \\
\text { - priorização de processos a serem } \\
\text { melhorados, a partir da análise de variáveis } \\
\text { que impactam o objetivo principal da } \\
\text { demanda em questão; } \\
\text { - discussão da viabilidade de implantação das } \\
\text { melhorias com envolvidos no processo; } \\
\text { - atribuição de "dono" do processo, } \\
\text { estabelecido na formalização da demanda, } \\
\text { junto ao apoio de um sponsor da alta } \\
\text { diretoria; no entanto não há atribuição de } \\
\text { "dono" para cada sub-processo do projeto } \\
\text { de melhoria de processos; }\end{array}$ & $\begin{array}{l}\text { - foco em melhoria de processos contínua, sem ter } \\
\text { vivenciado iniciativas estruturadas do tipo Lean } \\
\text { Production, Kaizen, Six Sigma ou ainda } \\
\text { reengenharia de processos; } \\
\text { - coleta de informações extraindo subsídios } \\
\text { suficientes para estabelecer panorama geral da } \\
\text { situação, através de fluxo do processo, sem } \\
\text { detalhes específicos; } \\
\text { - levantamento de histórico de dados e fatos como } \\
\text { insumos para comparar as situações anterior e } \\
\text { posterior à implementação de qualquer novo } \\
\text { processo a ser implementado; } \\
\text { - novo processo planejado para usuário do processo, } \\
\text { entendendo suas necessidades e convidando-o a } \\
\text { participar das decisões, evitando-se a criação de } \\
\text { resistências nas áreas; } \\
\text { - para cada macro-processo da cadeia de valor } \\
\text { existe um único dono de processo, geralmente } \\
\text { gestor da área que esteja presente no dia a dia de } \\
\text { sua atuaçãa; } \\
\text { - dono do processo e seu papel ainda não são } \\
\text { divulgados maciçamente para todos os níveis da } \\
\text { empresa, apenas alta hierarquia (presidência, vice- } \\
\text { presidência e diretoria); } \\
\text { - em caso de novo processo consolidado, realiza-se } \\
\text { transferência de dono de processo da área de } \\
\text { Qualidade e Processos para área responsável por } \\
\text { aquele processo, transferindo também } \\
\text { conhecimento do negócio, contatos, etc.; }\end{array}$ & $\begin{array}{l}\text { - vivenciou "reengenharia de processos", porém } \\
\text { muito mais ligada às pessoas que ocupavam os } \\
\text { cargos do que aos processos em si da empresa; } \\
\text { - pratica melhoria contínua de processos, sem ter } \\
\text { aplicado formalmente iniciativas estruturadas } \\
\text { do tipo Lean Production, Kaizen ou Six Sigma, } \\
\text { somente ciclo PDCA; } \\
\text { - mapeamento de processo realizado junto aos } \\
\text { executores das atividades, através de entrevista } \\
\text { in loco, sem metodologia específica para } \\
\text { realizar a entrevista; } \\
\text { - validação formal via email ou assinatura (sem } \\
\text { obrigatoriedade de arquivamento da mesma) } \\
\text { com objetivo de obter comprometimento dos } \\
\text { envolvidos; } \\
\text { - mapeamento evidencia para envolvidos sua } \\
\text { participação e impacto de suas atividades sobre } \\
\text { as demais; } \\
\text { - processos detalhados em fluxos, procedimentos } \\
\text { e políticas, dependendo do projeto de melhoria } \\
\text { que área de Processos está atuando, público } \\
\text { alvo a ser atingido e grau de confidencialidade } \\
\text { das informações em questão; } \\
\text { dono do processo claramente apresentado } \\
\text { como responsável pelo processo, atuando na } \\
\text { alteração e revisão de procedimento, inclusão } \\
\text { de novas atividades, acompanhamento do } \\
\text { processo como um todo e envolvimento das } \\
\text { áreas participantes; }\end{array}$ \\
\hline
\end{tabular}




\begin{tabular}{l}
$\begin{array}{c}\text { Conceitos da } \\
\text { Literatura }\end{array}$ \\
\hline (3.4)
\end{tabular}

Implementação de

melhoria de

processos

Dificuldades

\section{Caso A}

Caso B

Caso $C$

- metodologia própria para melhoria de $\bullet$ utiliza tanto apanhado de conceitos e técnicas processos, baseada na cultura acadêmicas quanto de boas práticas de mercado, organizacional, no benchmarking de não se fixando metodologia específica;

serviços prestados por consultorias externas • foco e disciplina em obter soluções práticas, de e experiência da equipe, e em conceitos da literatura clássica adaptados à realidade da empresa;

- fases: entendimento processo, mapeamento As Is, análise de riscos e controles, formalização e publicação dos processos, priorização das melhorias, modelagem To $B e$, implementação de plano de ação.

- humanas: áreas podem deixar de enxergar os resultados do projeto de melhoria optando por executar somente as atividades operacionais do dia a dia;

- de tempo e recursos financeiros: quando se necessita reduzir despesas, dependência de financiamento de outras áreas pode interromper projetos de melhoria de processos pois estes não são encarados como prioridade;

- técnicas, de tecnologia e metodologia: capacidade e prazo da área de TI para atender novas demandas pode limitar implementação de ações de melhoria;

- política e gestão: dificuldades de gestão na implementação de melhorias devido à problemas (comunicação, mudança de interlocutores, etc.) na transição do projeto do Núcleo de Processos para área demandante ou Escritório de Projetos: simples implementação, com ganhos rápidos, • etapas: planejar (identificar problema, analisar embasados por estudos históricos da realidade;

- não há etapas formalmente nominadas, porém podemos resumir em: identificação do problema, estabelecimento de plano de ação, desdobramento de resultados e formalização do processo

humanas: eventuais resistência de colaboradores em aceitar mudanças; para minimizar efeitos, realização de política de bastidores e participação de diretores na construção de novo processo (captar comentários construtivos, sentir-se parte do processo);

- de tempo e recursos financeiros: falta de tempo para implantar a solução ótima; reaproveitamento de recursos disponíveis para se atingir os bons resultados possíveis;

técnicas, de tecnologia e metodologia: alta demanda para área de TI sendo sua prioridade diferente de Qualidade e Processos; estabelecimento de parcerias (ex.: agência de viagens) para implantar sistemas e minimizar efeitos; novo ambiente de trabalho suplantado por treinamentos e atuação do gestor; problema, identificar causas fundamentais, estabelecer plano de ação); executar (educar e treinar para executar plano de ação, executar trabalho conforme plano de ação e coletar dados); avaliar (avaliar execução de ações e avaliar resultados); atuar (padronizar ações bem sucedidas, tratar desvios)

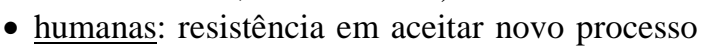
evitada com trabalho prévio envolvendo pessoas durante proposta de novo processo;

- de tempo e recursos financeiros: equipe enxuta, traz bons resultados, mas demanda é maior do que a equipe pode atender, sendo necessários recursos financeiros para contratar mais gente capacitada para atender demandas;

- técnicas, de tecnologia e metodologia: dificuldades técnicas para realização de treinamento no novo processo (lojas em todo Brasil, regionalidades, alto índice de rotatividade e disponibilidade dos colaboradores de chão de loja);

política e gestão: dificuldades no canal de comunicação entre loja e matriz; perda de informações ao longo do tempo (alta rotatividade de colaboradores de loja, grande quantidade de lojas e questões culturais conforme região do país onde a loja esteja presente); dificuldade em garantir que executores sigam procedimento estabelecido; política e gestão: poucas vezes há desconforto com 


\begin{tabular}{|c|c|}
\hline $\begin{array}{c}\text { Conceitos da } \\
\text { Literatura }\end{array}$ & Caso A \\
\hline $\begin{array}{l}\checkmark \text { Fatores críticos } \\
\text { de sucesso }\end{array}$ & $\begin{array}{l}\text { - apoio da alta gestão: Núcleo de Processos } \\
\text { atrelado à vice-presidência financeira, mas } \\
\text { dependente de patrocinador do projeto; } \\
\text { - alinhamento estratégico: projetos de } \\
\text { melhoria de processos não são } \\
\text { necessariamente fruto de desdobramento do } \\
\text { planejamento estratégico apesar de serem } \\
\text { justificados por critérios pré-estabelecidos; } \\
\text { - avaliação de desempenho e efeito de } \\
\text { demonstração: apresenta aos envolvidos as } \\
\text { consequiências de melhorias a serem } \\
\text { implementadas, mas não necessariamente } \\
\text { demonstra através de resultados } \\
\text { concretamente atingidos; }\end{array}$ \\
\hline
\end{tabular}

- presença de liderança: Núcleo de Processos responsável por conduzir reuniões, mapear, e promover melhoria de processos, desenvolver plano de ação gera interesse de envolvidos a resolver dificuldades esquecidas no dia-a-dia da organização;

- uso efetivo de tecnologia de informação: utilização de software para registro de fluxos, detalhamento funcional, sistemas documentos utilizados nos processos; análise de capacidade e prazo da área de TI para atender novas demandas;

- comunicação e transferência de conhecimento: atenção na transição de líder de projeto, para área demandante ou Escritório de Projetos, no momento de implementação de plano de ação; utilização de documentação padrão para comunicação

- apoio da alta gestão: Presidência é principal patrocinadora da área de Qualidade e Processos atuar como facilitadora para demais áreas buscarem melhoria dos processos;

- alinhamento estratégico: busca de melhoria de resultados para empresa mas não necessariamente alinhado a objetivos estratégicos;

- avaliação de desempenho e efeito de demonstração: preocupação em mostrar resultados de forma relativamente rápida balanceando o quão detalhista ser e o quanto de resultado se pretende atingir; realização de projeto piloto permite ajustar pontos inadequados da solução proposta e utilizar os resultados obtidos como vitrine do plano de ação em escala global na empresa;

- presença de liderança: área de Qualidade e Processos conduzindo projetos de melhoria de processos com autonomia para convidar envolvidos a elaborar novo processo;

- uso efetivo de tecnologia de informação: processos mapeados registrados em sistema; desenvolvimento de sistema de apoio para melhorar processo (exemplo do processo de gestão de viagens corporativas);

comunicação e transferência de conhecimento: comunicação eficiente sobre novo processo através de correio eletrônico, portal e conversa de bastidores, auxiliando aceitação e destacando papel dos gestores para orientar funcionários; transição de dono do processo, com foco em conquistar comprometimento do novo gestor;
- apoio da alta gestão: área de Processos patrocinada por Diretoria Executiva Financeira; Presidente valoriza publicamente em reuniões abordagem de processos; comprometimento da alta hierarquia para desempenhar o processo de forma adequada;

- alinhamento estratégico: utilização de processos na melhoria de resultados da empresa, o que não significa atuar conforme planejamento estratégico da empresa;

avaliação de desempenho e efeito de demonstracão: negociação com áreas baseando-se em fatos e argumentos concretos focados em resultados para empresa, buscando obter apoio de áreas fundamentais do processo em questão;

- presença de liderança: área de Processos neutra, com bom relacionamento e facilidade de acesso às áreas da matriz e loja, promove debates na busca de solução de problemas (diminui resistências, participação conjunta nas definições de novo processo)

uso efetivo de tecnologia de informação: software utilizado como apoio para formalizar fluxo; utilização de dados de sistema para monitorar processo (exemplo de acompanhar, via sistema, alterações de estoque realizadas no processo de inventário em loja);

- comunicacãa e transferência de conhecimento: divulgação formal de procedimento em portal e via correio eletrônico destacando apoio dos diretores envolvidos; comunicação eficaz aos executores de atividades do novo processo; material de treinamento com foco no usuário (linguagem didática e detalhada, figuras, etc.);

Continuação 


\begin{tabular}{|c|c|c|c|}
\hline $\begin{array}{c}\text { Conceitos da } \\
\text { Literatura }\end{array}$ & Caso A & Caso B & Caso C \\
\hline $\begin{array}{ll}\checkmark & \text { Fatores críticos } \\
\text { de sucesso }\end{array}$ & $\begin{array}{l}\text { - } \text { rigor na implementação de melhorias: uso } \\
\text { de metodologia formal para implementação } \\
\text { de melhorias; } \\
\text { - gestão da mudança em recursos humanos: } \\
\text { discussão da viabilidade de implantação das } \\
\text { melhorias (redefinição de atividades) com } \\
\text { envolvidos no processo, validando } \\
\text { formalmente desenho As Is e To Be; } \\
\text { - } \frac{\text { seleção criteriosa de colaboradores: }}{\text { atribuição de um dono do processo, }} \\
\text { participação e comprometimento de } \\
\text { envolvidos na proposta de novo processo; } \\
\text { - concorrência de mercado: dinamismo do } \\
\text { varejo faz projetos de melhoria depender } \\
\text { completamente da realidade vivenciada pela } \\
\text { empresa, como por exemplo, redução de } \\
\text { despesas pode implicar em interromper } \\
\text { projetos de melhoria de processos; }\end{array}$ & $\begin{array}{l}\text { - } \text { rigor na implementação de melhorias: não segue } \\
\text { necessariamente rigor metodológico fixo, mas } \\
\text { planeja e realiza ações de maneira estruturada e } \\
\text { adaptada à necessidade; } \\
\text { - gestão da mudança em recursos humanos: } \\
\text { Qualidade e Processos como facilitadora e isenta, } \\
\text { foco nas melhorias para a empresa como um todo, } \\
\text { trabalho de bastidores junto aos envolvidos, } \\
\text { diminuindo resistências ao novo processo; } \\
\text { - seleção criteriosa de colaboradores: participação de } \\
\text { envolvidos para propor novo processo; definição } \\
\text { de dono do processo que esteja presente no dia a } \\
\text { dia de sua atuação; } \\
\text { concorrência de mercado: varejo exige resultados } \\
\text { rápidos sem se desviar das atividades previamente } \\
\text { estabelecidas mesmo frente a problemas } \\
\text { vivenciados no dia a dia das lojas. }\end{array}$ & $\begin{array}{l}\text { - rigor na implementação de melhorias: } \\
\text { utilização de metodologia estruturada (ciclo } \\
\text { PDCA); empenho de esforços e tempo durante } \\
\text { planejamento (análise de possíveis } \\
\text { divergências para evitar revisões de trabalho), } \\
\text { facilitando implantação de plano de ação; } \\
\text { - gestão da mudança em recursos humanos: área } \\
\text { de Processos promovendo reconstrução de } \\
\text { procedimentos; treinamento e capacitação de } \\
\text { colaboradores com objetivo de padronizar a } \\
\text { execução de novo processo; } \\
\text { - seleção criteriosa de colaboradores: apoio de } \\
\text { áreas capazes de intermediar orientações da } \\
\text { matriz e realidade do dia a dia de loja } \\
\text { (exemplo da equipe de Prevenção de Perdas } \\
\text { acionada para treinar colaboradores de loja no } \\
\text { novo processo de inventário); colaborador } \\
\text { designado para esclarecer dúvidas das lojas na } \\
\text { execução de atividades descritas em } \\
\text { procedimento; } \\
\text { concorrência de mercado: empresa presente } \\
\text { em todo Brasil, regionalidades e turnover de } \\
\text { colaboradores; balancear cultura de processos } \\
\text { recente com exigência de resultados imediatos; }\end{array}$ \\
\hline $\begin{array}{l}\text { (3.5) Indicadores } \\
\text { de Processo }\end{array}$ & $\begin{array}{l}\text { - não trabalha com identificação e definição } \\
\text { de indicadores de desempenho de processo, } \\
\text { devidamente consistentes com a missão } \\
\text { estabelecida para o mesmo; } \\
\text { - algumas vezes ocorre apenas a análise } \\
\text { histórica de dados que possam refletir a(s) } \\
\text { melhoria(s) implantada(s); } \\
\text { - não há indicadores claros e consistentes } \\
\text { ligando os processos mapeados a objetivos } \\
\text { concretos e ou estratégicos da empresa. }\end{array}$ & $\begin{array}{l}\text { - atribuição de indicadores que garantam criação de } \\
\text { histórico de dados de forma que dono do processo } \\
\text { possa realizar supervisão e acompanhamento de } \\
\text { resultados conforme metas planejadas; } \\
\text { - indicadores não são formalmente alinhados com a } \\
\text { perspectiva estratégica da empresa ou ainda } \\
\text { relacionados ao cliente final; } \\
\text { - indicadores avaliam desempenho do processo em } \\
\text { si, de forma a permitir, analisar potencial de } \\
\text { melhoria contínua daquele processo. }\end{array}$ & $\begin{array}{l}\text { - definição de indicadores, chamados pontos de } \\
\text { controle, para monitorar periodicamente } \\
\text { atividades realizadas e verificar se } \\
\text { colaboradores cumprem tarefas conforme } \\
\text { foram capacitados; } \\
\text { - indicadores de resultados obtidos com a } \\
\text { melhoria do processo e não necessariamente } \\
\text { indicadores de nível de serviço ou ainda de } \\
\text { alinhamento com cliente final em uma } \\
\text { perspectiva estratégica da empresa. }\end{array}$ \\
\hline
\end{tabular}
melhoria contínua daquele processo. 